\title{
Overview of Pretreatment Methods Employed on Oil Palm Biomass in Producing Value-added Products: A Review
}

\author{
Rushan Diyanilla, ${ }^{\mathrm{a}}$ Tuan Sherwyn Hamidon, ${ }^{\mathrm{a}}$ Lisman Suryanegara, ${ }^{\mathrm{b}}$ and \\ M. Hazwan Hussin ${ }^{\mathrm{a}, *}$
}

\begin{abstract}
Oil palm biomass is readily available in Malaysia. However, its high lignin content makes it undesirable for further processing. Pretreatment is employed to reduce the amount of lignin. Many resources exist on pretreatment methods for lignocellulosic biomass, but there are few articles specifically on oil palm biomass. Therefore, this review focuses on pretreatment methods for oil palm biomass, comparing their main strengths and limitations. Furthermore, this review tabulates different pretreatment conditions utilized, combinations of pretreatment methods, the resulting yields, and the potential applicability in producing valueadded products. Because the main limitation of pretreatment is the formation of toxic compounds such as furfural and hydroxymethylfurfural, this review also discusses chemical detoxification methods for oil palm biomass residues. According to this review, among all types of oil palm biomass, oil palm empty fruit brunch is the most widely studied, and alkaline pretreatment is the most popular of all pretreatment methods. Combination of pretreatment methods is suitable for biomass with greater lignin content, to increase delignification efficiency. Furthermore, a combination of overliming and activated carbon treatment removes the maximum amount of toxic by-products.
\end{abstract}

Keywords: Oil palm; Cellulose; Lignin; Pretreatment; Detoxification

Contact information: a: Materials Technology Research Group (MaTReC), School of Chemical Sciences, Universiti Sains Malaysia, 11800 Minden, Penang, Malaysia; $b$ : Research Center for Biomaterials, Indonesian Institute of Sciences (LIPI), Jakarta, Indonesia;

*Corresponding author:mhh@usm.my; mhh.usm@gmail.com

\section{INTRODUCTION}

Over the past decades, the world's energy demand has been growing rapidly. Conventional energy resources such as coal, oil, petroleum, and natural gas are growing more scarce, and use of fossil fuels causes climate change (Tsegaye et al. 2019; Trache et al. 2020). Thus, available energy resources need to be conserved while exploring sustainable alternatives, such as conversion of renewable energy materials to biofuels (Medina et al. 2018). To that end, available resources should be utilized efficiently while overcoming challenges such as solid waste management, environmental pollution, the greenhouse effect, and energy demand (Manaf et al. 2018; Charnnok et al. 2019).

Currently, the oil palm industry in Malaysia generates more than 80 million tons (dry weight basis) of oil palm waste per year (Megashah et al. 2018a; Yiin et al. 2018a), and this figure is expected to increase by at least $40 \%$ in 2020 (Rupani et al. 2019). Corresponding to a proposed increase in oil palm plantations in Malaysia, annual oil palm production is expected to increase by up to 50 million tons by 2030 (Tahir et al. 2018). 
Palm kernel shell (PKS) (Lee et al. 2018), oil palm empty fruit bunch (OPEFB), oil palm frond (OPF), oil palm mesocarp fiber (OPMF), oil palm leaves (OPL), palm oil mill effluent (POME), palm kernel cake (PKC), and oil palm trunk (OPT) are the most generated co-products (Fig. 1) (Rafatullah et al. 2013; Brito et al. 2018; Chan et al. 2018). The total oil palm biomass residues (dry weight basis) (Fig. 2) available for replanting, pruning, and milling activities in Malaysia in 2017 was assessed 51.19 metric tons (MT) out of 101.02 MT of oil palm fresh fruit bunches (OPFFB) processed (Hamzah et al. 2019).

Meanwhile, researchers worldwide are performing new experiments to maximize the usage of oil palm biomass. So far, many studies have been performed on the technological advancements in the use of oil palm biomass for the production of biochar, polymers, and biofuels (Hassan et al. 2019; Hussin et al. 2020). With the increasing demand for alternatives to fossil fuels and the depletion of fossil fuel reservoirs, studies are proceeding toward the production of biofuels (Chang 2018). With the increase in population, demand for food sources has also increased. Therefore, the current interest is more towards the production of biofuels from non-edible sources (Razali et al. 2018). Consequently, biofuels produced from oil palm biomass have attracted the attention of many researchers.

Malaysia is globally renowned for its palm cultivation, being the world's secondlargest palm oil producer and exporter (Tajuddin et al. 2019), accounting for more than $30 \%$ of world palm oil production and $37 \%$ of world exports in 2016 (Rizal et al. 2018a). Therefore, great amounts of oil palm biomass are generated annually and then thrown out or burnt without further utilization due to the lack of technology to utilize this material (Onoja et al. 2019). This situation worsens the biomass overload problem, wastes precious cellulose-rich resources, and can lead to serious environmental issues such as air pollution (Latif et al. 2019). Lignocellulosic biomass is the most readily available renewable green carbon source generated on earth and presents potential alternatives to petroleum-based commodity crops (Ahmad et al. 2018a; Tayyab et al. 2018). Lignocellulosic biomass provides raw materials for potential renewable energy sources due to its carbohydrate composition (Megashah et al. 2018b). It can be used to produce biofuels such as bioethanol, biobutanol (Espinosa et al. 2018), and biomethane (Medina et al. 2018), along with various other value-added products (Kamsani et al. 2018; Namondo et al. 2018). Secondgeneration bioethanol is the most advanced product generated from lignocellulosic biomass (Perrone et al. 2018).

As the name implies, lignocellulosic biomass contains lignin (aromatic biopolymer), as well as cellulose and hemicellulose (polysaccharides) as major components (Rizal et al. 2018a; Thamsee et al. 2019). Only the cellulose and hemicellulose are further converted to ethanol. However, due to the high amount of lignin present in the cell wall, utilization of oil produced from the palm is difficult. Lignins are complex structures that are resistant to further conversion (Cardona et al. 2018). Therefore, before the primary processing steps of enzymatic hydrolysis, fermentation, and distillation, some preparation steps are required to digest these resistant structures (i.e., to reduce biomass recalcitrance) and open them up for further conversion (Satlewal et al. 2018; Sukiran et al. 2018). These preparation steps (delignification) are known as pretreatment methods.

An effective pretreatment method alters the chemical composition of lignocellulosic biomass, its macrostructure, and its microstructure. Apart from delignification, pretreatment methods reduce the crystallinity of cellulose and improve the porosity of the lignocellulosic material (Noorshamsiana et al. 2017; Sasmal and Mohanty 2018). Moreover, a resourceful pretreatment technique must be cheap, be easy to operate, 
and form a substantial percentage of the yield (Tayyab et al. 2018). The pretreatment method should be selected based on the amount of lignin present in the studied oil palm biomass. Based on the research studies analyzed in this review article, the amount of lignin present in different types of oil palm biomass varies drastically (approximately $14 \%$ to $36 \%$ ). The greatest amount of lignin is present in oil palm mesocarp (OPMF), and the lowest amount of lignin is present in OPEFB.

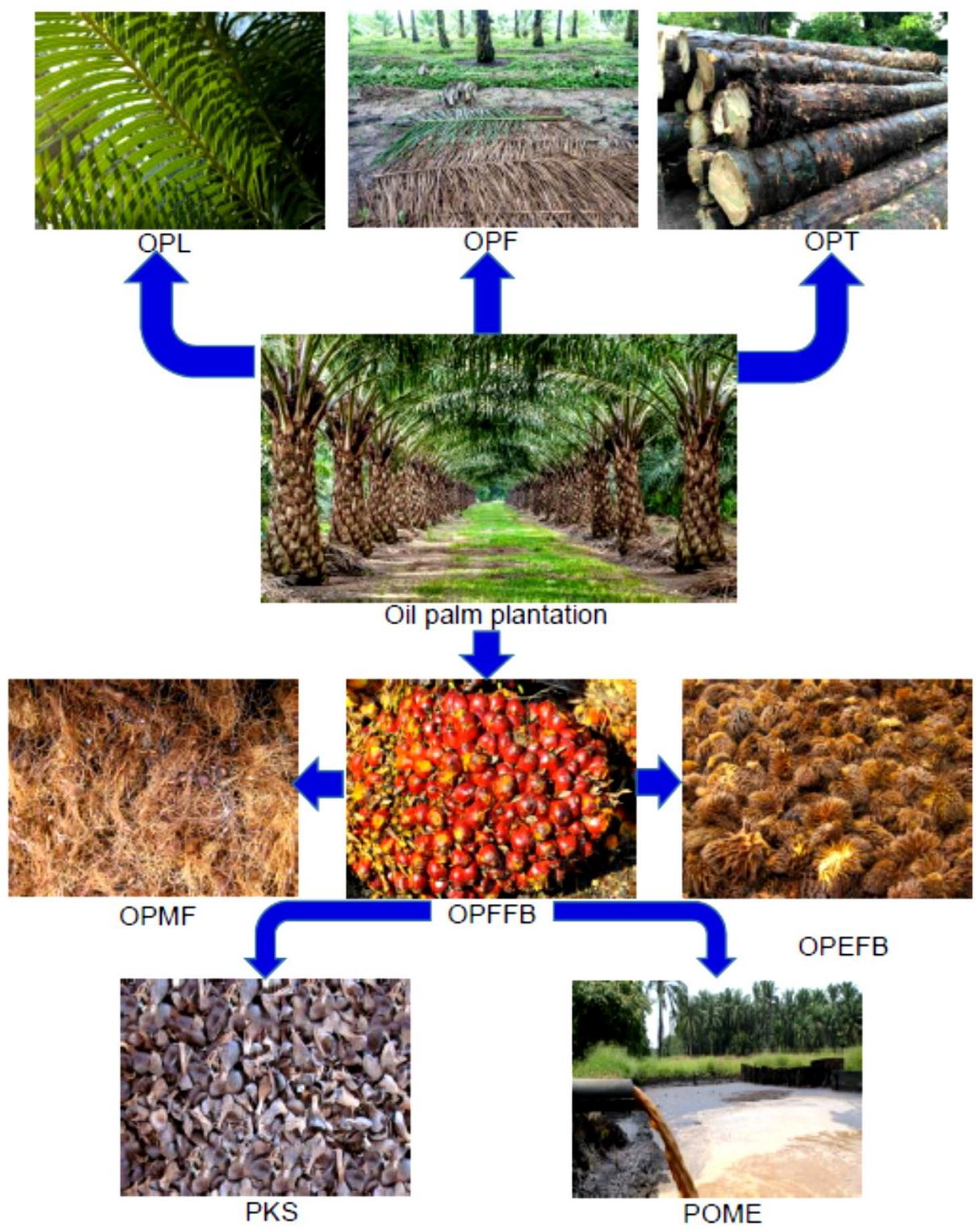

Fig. 1. Major oil palm biomass residues 
Most of the studies performed on oil palm biomass are on OPEFB. Apart from OPEFB having the greatest availability, the ease of performing chemical reactions due to the lower lignin content may contribute to its popularity. However, due to the limited number of studies performed on PPF, it is difficult to compare the amounts of lignin observed in different studies. One notable feature found was the deviation in the lignin content of a specific type of biomass when comparing various studies. The cellulose, hemicellulose, and lignin contents of different types of oil palm biomass are summarized in Table 1, as different studies reported varied lignin contents even among a specific type of oil palm biomass. This result may be due to several factors, such as the area the plant is grown, the constituents of the soil, nutritional levels, and climatic changes, which affect the amount of lignin present in order to adapt to nature. Therefore, a researcher planning to work on a particular type of oil palm biomass should first analyze the lignin content before selecting the pretreatment method.

Table 1. Cellulose, Hemicellulose, and Lignin Contents of Different Types of Oil Palm Biomass

\begin{tabular}{|c|c|c|c|c|}
\hline $\begin{array}{l}\text { Oil Palm } \\
\text { Biomass }\end{array}$ & Cellulose (\%) & $\begin{array}{l}\text { Hemicellulose } \\
(\%)\end{array}$ & Lignin (\%) & References \\
\hline OPEFB & $32.80-43.56$ & $12.00-39.00$ & $14.25-38.41$ & $\begin{array}{c}\text { Chavalparit et al. (2018), Arbaain } \\
\text { et al. (2019), Waluyo et al. (2018), } \\
\text { Zulkarnain et al. (2018), Thamsee } \\
\text { et al. (2019) }\end{array}$ \\
\hline OPMF & $23.60-38.38$ & $22.30-36.74$ & $24.88-32.40$ & $\begin{array}{c}\text { Megashah et al. (2018b), } \\
\text { Norrrahim et al. (2018), Ahmad et } \\
\text { al. (2018b) }\end{array}$ \\
\hline OPT & $38.85-46.89$ & $22.11-23.84$ & $15.02-20.36$ & $\begin{array}{l}\text { Boon et al. (2019), Rattanaporn et } \\
\text { al. (2018), Thamsee et al. (2019) }\end{array}$ \\
\hline OPF & $30.70-38.36$ & $27.54-41.50$ & $16.74-27.80$ & $\begin{array}{c}\text { Mahmood et al. (2018), Thamsee } \\
\text { et al. (2019) }\end{array}$ \\
\hline PPF & $25.45 \pm 0.91$ & $17.35 \pm 0.54$ & $36.00 \pm 0.26$ & Brito et al. (2018) \\
\hline
\end{tabular}

These pretreatment methods can be divided into three main categories: physical pretreatment, chemical pretreatment, and biological pretreatment (Nabilah-Jansar et al. 2018). Of these methods, physical pretreatment and chemical pretreatment are widely used (Hosseini Koupaie et al. 2019) due to their low cost and user-friendliness (Noorshamsiana et al. 2017). However, with increasing demand for the use of environmentally benign methods, researchers have started to shift towards biological pretreatment methods, mainly due to reduced energy consumption, better productivity, the formation of non-toxic compounds, and greater specificity (Arora et al. 2019; Tsegaye et al. 2019).

Acid treatment, alkaline treatment, and organic solvent treatment are chemical treatment methods (Moniruzzaman and Goto 2018). Milling, pyrolysis, and hydrothermal treatment are examples of physical pretreatment (Tang et al. 2018). Enzymatic treatment and treatment using microorganisms are biological pretreatment methods. In the production of 
biofuel, the choice of pretreatment method mainly depends on the nature of the biomass used, the generation of toxic inhibitors, and the amount of lignin present (Kumar et al. 2019). Also, special consideration should be given to cost-effectiveness and the effects on the final product and its composition (Kim 2018; Tayyab et al. 2018). Furthermore, ease of expanding to industrial scale should be given a high value.

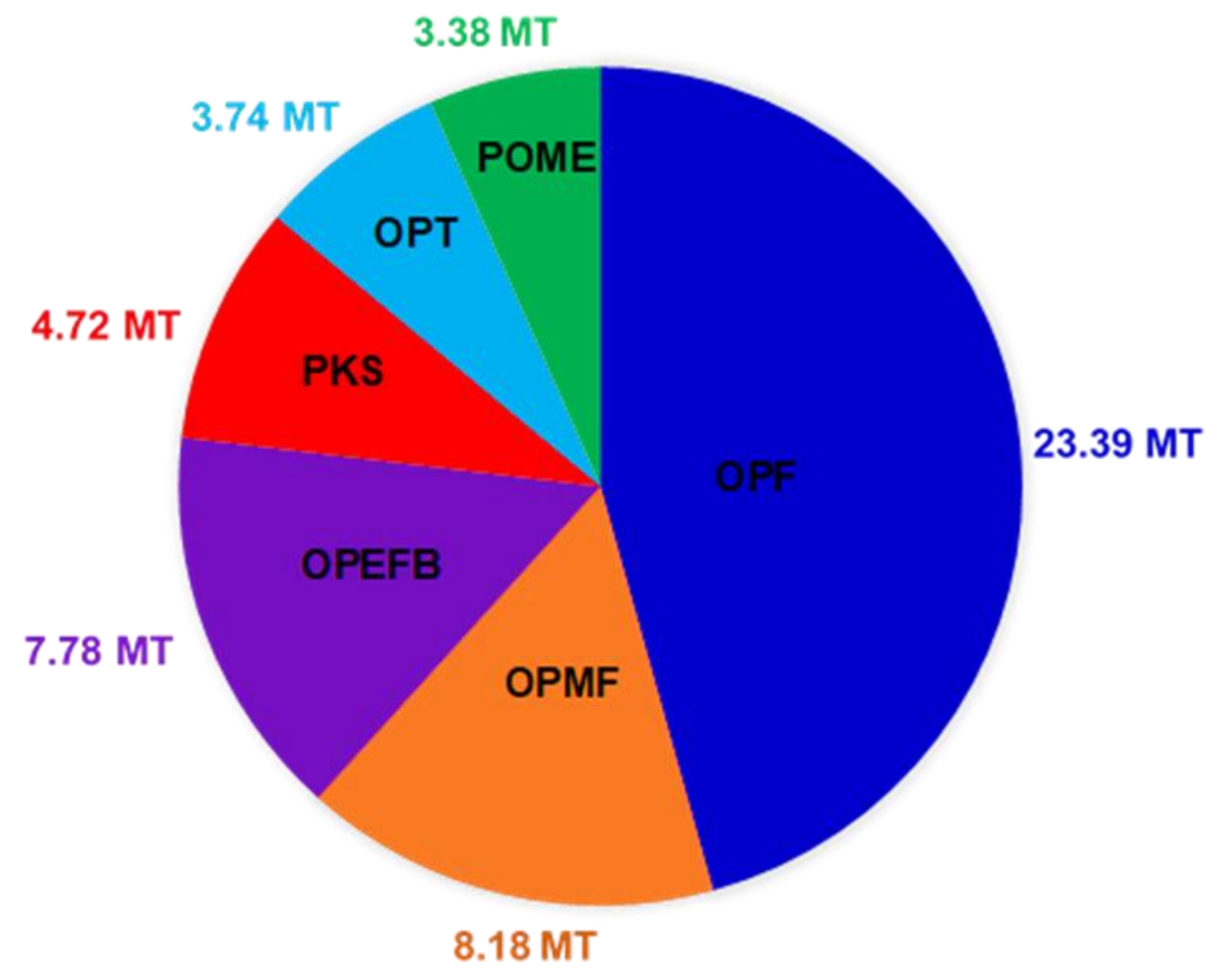

Fig. 2. Availability of major oil palm biomass residues (dry weight) in Malaysia in 2017

Many review articles have been written on pretreatment methods in general. For instance, Rizal et al. (2018a) reviewed the pretreatment of oil palm biomass for fermentable sugar production. Even though their review study focused on different pretreatment techniques employed on oil palm biomass, the review paper does not reach beyond explaining post-production from fermentable sugars. Their study does not enlighten about the production of value-added products from fermentable sugars. Moreover, how each pretreatment technique affects the production of fermentable sugars has not been discussed. Apart from that, Rizal et al. (2018a) have not discussed each pretreatment method in detail. To the best of the present authors' knowledge, there have been little to no studies regarding the various pretreatment techniques employed on oil palm biomass in the production of value-added products. There has been a need for in-depth review of literature detailing how each pretreatment technique influence the digestibility of oil palm biomass in valorizing them into value-added products including bioethanol, lactic acid, vanillic acid, biovanillin, biohydrogen, 2,3-butanediol, pyrolysis oil, protocatechuic acid, vanillin, cellulose nanocrystals, as antioxidants, and transparent paper production. Apart from conventional techniques, the present review also deliberates emerging pretreatment technologies employed on oil palm biomass as promising sustainable green pretreatment methods including microwave irradiation, ultrasonication, and ultra-high pressure. Additionally, this review focused on comparing the salient features and limitations of different 
pretreatment methods, while describing the different reaction conditions used on different types of oil palm biomass. Emphasis was also given to several detoxification methods for the removal of toxic by-products produced during the pretreatment process. Therefore, this review paper serves to highlight and discuss the vast potential of an effective pretreatment to overcome the recalcitrance of oil palm biomass and may guide researchers and practitioners in designing their setups according to their needs.

\section{CHEMICAL PRETREATMENT}

Of all the existing pretreatment methods, chemical pretreatments are the most widely used. Chemical pretreatments can be subdivided according to the type of chemical being used. As the name implies, the pretreatment is performed via a chemical reaction, which leads to the disruption of the bonds among cellulose, hemicellulose, and lignin (Noorshamsiana et al. 2017).

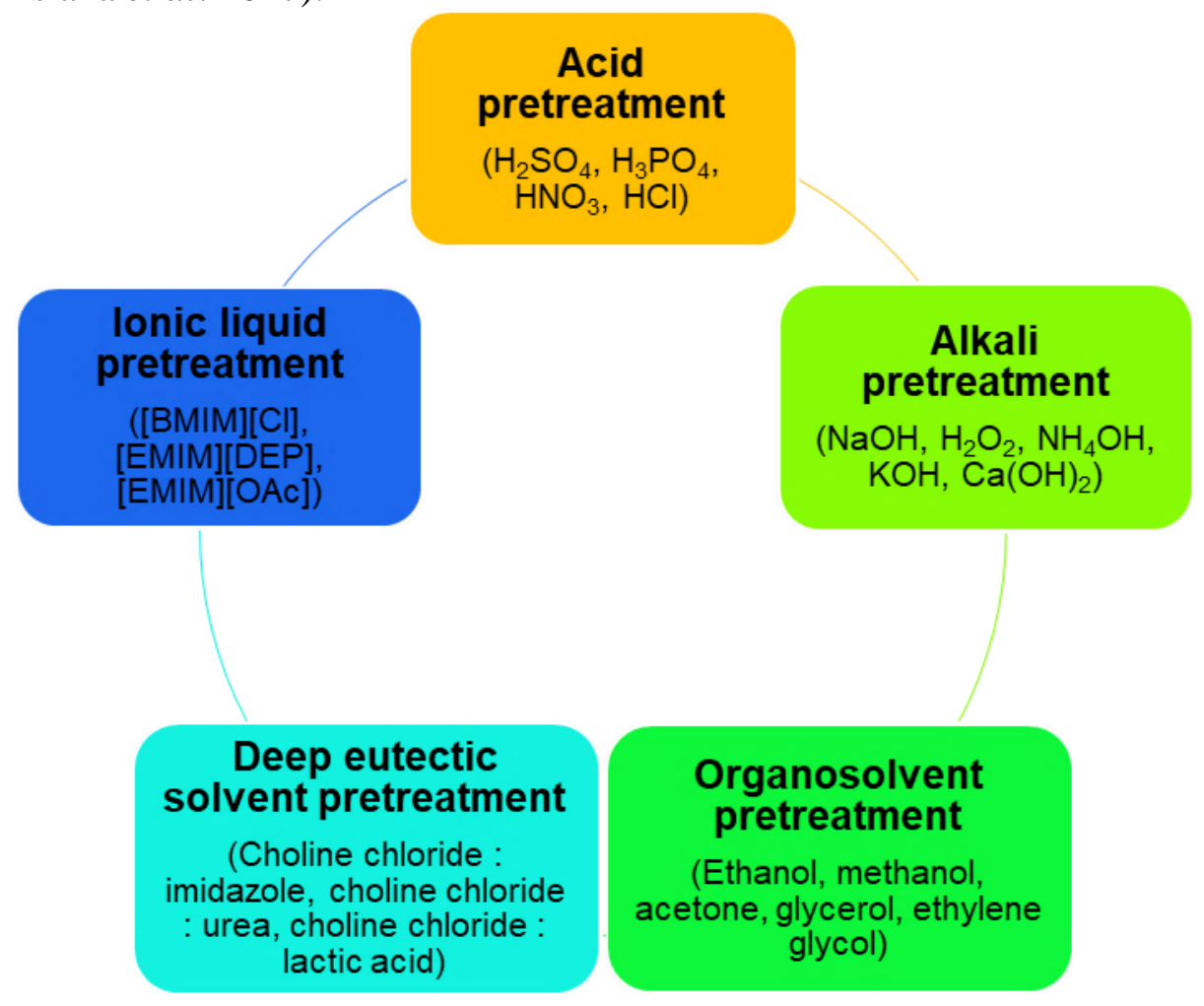

Fig. 3. Main chemical pretreatment methods employed on oil palm biomass

The main chemical pretreatment types are acid pretreatment, alkaline pretreatment, organosolvent pretreatment, deep eutectic solvent pretreatment, and ionic liquid pretreatment, as depicted in Fig. 3. For instance, Loow and Wu (2018) employed a novel approach studying the efficiency of transformation of OPF into pentose sugars (xylose and arabinose) using an inorganic salt pretreatment, $\mathrm{CuSO}_{4} \cdot 5 \mathrm{H}_{2} \mathrm{O}$, with the assistance of chemical additives $\left(\mathrm{H}_{2} \mathrm{O}_{2}\right.$ and $\left.\mathrm{Na}_{2} \mathrm{~S}_{2} \mathrm{O}_{8}\right)$. The study reflected the importance of using chemical additives with the inorganic salt pretreatment of OPF. The results showed that the addition of $4.5 \mathrm{vol} \%$ of $\mathrm{Na}_{2} \mathrm{~S}_{2} \mathrm{O}_{8}$ during the $\mathrm{CuSO}_{4} \cdot 5 \mathrm{H}_{2} \mathrm{O}$ pretreatment at $120{ }^{\circ} \mathrm{C}$ for 30 min was able to achieve a total pentose sugar yield up to approximately $40 \%$. Table 2 
lists some of the chemical pretreatment methods used on oil palm biomass, including the reaction conditions that were employed and the outcome of each technique.

\section{Acid Pretreatment}

Acid pretreatment can effectively alter the chemical structures of lignocellulose. Acids employed in acid pretreatment work as catalysts to hydrolyze carbohydrates (especially hemicellulose), thereby weakening the lignin-hemicellulose barrier (Risanto et al. 2018). Acid pretreatment can be performed using mild acids as well as concentrated acids (Zhai et al. 2018). However, the reaction conditions will be different according to the strength of the acid being used. Typically, concentrated acids (30\% to $70 \%)$ are employed at temperatures less than $100{ }^{\circ} \mathrm{C}$, while dilute acids $(0.1 \%$ to $10 \%)$ are employed at temperatures between 120 and $200{ }^{\circ} \mathrm{C}$ (Sari et al. 2018). The common inorganic acids used for acid pretreatment are $\mathrm{H}_{2} \mathrm{SO}_{4}, \mathrm{H}_{3} \mathrm{PO}_{4}, \mathrm{HNO}_{3}$, and $\mathrm{HCl}$ (Manaf et al. 2018). Apart from inorganic acids, organic acids are also used for pretreatment and do not generate additional lignocellulose-derived compounds during the fermentation process. Organic acids such as formic acid, maleic acid, oxalic acid, acetic acid, and citric acid (Oktaviani et al. 2019) are used for chemical pretreatment. Shrinking-bed, batch percolation, plug flow, flow-through, and counter-current reactors are the types of reactors that can be used for acid pretreatment (Kapoor et al. 2018).

Acid pretreatment is widely used, as it has many advantages. Dilute acids are more suitable because there is no need to recycle; they have a high reaction rate and can be used for continuous production. In the subsequent steps, the use of dilute acids will lead to high glucan hydrolysis and high xylose production. Also, when dilute $\mathrm{H}_{3} \mathrm{PO}_{4}$ and $\mathrm{H}_{2} \mathrm{SO}_{4}$ are employed, the essential nutrients phosphorous (P) and sulfur (S) aid the fermentation (Kapoor et al. 2018). Furthermore, at low pH, microorganisms used in the subsequent steps are able to adjust to the environment (Singh et al. 2018). Organic acids are less toxic and produce comparatively fewer inhibitory compounds in the hydrolyzate, as well as minimal sugar degradation (Oktaviani et al. 2019).

Despite these advantages, there are some drawbacks to consider when using acid pretreatment. The main downside is that a severer pretreatment such as acid pretreatment would dissolve more cellulose and hemicellulose. Additionally, acid-catalyzed hydrolysis would lead to the degradation of fermentable sugars to form inhibitory products, including furfural and hydroxymethylfurfural (HMF). HMF and furfural diminish the yield of fermentable sugars in the pretreatment liquor and concurrently serve as fermentation inhibitors. These inhibitory products should be removed or reduced through detoxification before the sugars can be fermented into ethanol or other value-added products (Noparat $e t$ al. 2015). Acid pretreatment causes starch to degrade to form HMF under severer conditions. For an example, if OPT is subjected to acid pretreatment, starch loss would be inevitable (Eom et al. 2015). Moreover, there are other drawbacks, including the need to use individual reactors to withstand corrosion, increasing operational and maintenance costs. Subsequent detoxification, washing, and neutralizing should be done before further processing, which increases the time and cost (Noorshamsiana et al. 2017). Partial degradation of lignin forms phenolic compounds that will cause interference in the subsequent steps of hydrolysis. Highly acidic conditions may lead to further hydrolysis of hemicellulose into xylose, which can be further hydrolyzed to furfural and HMF. However, this can also be used to commercially synthesize furfural. Hastuti et al. (2018) extracted cellulose nanocrystals (CNCs) from OPEFB via hydrochloric acid pretreatment. They concluded that CNCs isolated by hydrochloric acid pretreatment persisted stably for more 
than 6 months without undergoing any sedimentation, demonstrating superior nanodispersibility.

Oil palm empty fruit bunch is the most widely used type of biomass available from the oil palm tree. The reason for this may be the abundance of OPEFB upon palm oil extraction for other industrial applications. Mostly, dilute $\mathrm{H}_{2} \mathrm{SO}_{4}, \mathrm{HNO}_{3}$, and acetic acid have been applied as the acid pretreatment medium. According to Gonzales et al. (2019) and Thamsee et al. (2018), the glucose yield is reduced when using high temperatures for an extended time. Oil palm trunk is the next highly used oil palm biomass. Rattanaporn et al. (2018) achieved the greatest reducing sugar yield with the use of oxalic acid, compared to acetic acid and citric acid. According to the aforementioned studies, both PPF and OPF have been employed with dilute $\mathrm{H}_{2} \mathrm{SO}_{4}$ as the pretreatment agent. However, comparison of the results is difficult due to the limited number of studies conducted.

Noparat et al. (2015) employed dilute acid pretreatment on OPT biomass under varying conditions (temperature, acid concentration, and time) to improve enzymatic saccharification. A fractional factorial experiment design was adopted to investigate the pretreatment conditions needed to obtain high enzymatic digestibility. The data obtained indicated that mild acid pretreatment conserved more cellulose and hemicellulose; nevertheless, severe conditions were required to attain adequate enzymatic hydrolysis of OPT. According to their study, most of the hemicelluloses in OPT were removed through the acid pretreatment, while cellulose and lignin being more porous were easily hydrolyzed by cellulases into glucose. Effects of acid pretreatment and conditions on consequent enzymatic hydrolysis were evaluated upon hydrolyzing with the use of enzymes containing cellulase at a loading of $15 \mathrm{FPU} / \mathrm{g}$ cellulose and $\beta$-glucosidase at a loading of $30 \mathrm{CBU} / \mathrm{g}$ cellulose for $72 \mathrm{~h}$. They found that pretreating with $3 \% \mathrm{H}_{2} \mathrm{SO}_{4}$ for $40 \mathrm{~min}$ at $180{ }^{\circ} \mathrm{C}$ attained the highest enzymatic hydrolysis (cellulose-to-glucose conversion yield) of $c a$. $80 \%$ along with the highest overall glucose recovery $(50.8 \%)$, while $1 \% \mathrm{H}_{2} \mathrm{SO}_{4}$ pretreatment for 20 min at $160^{\circ} \mathrm{C}$ achieved the lowest cellulose to glucose conversion yield of $22 \%$ upon $72 \mathrm{~h}$ of digestion. Insufficient enzymatic hydrolysis achieved at $1 \% \mathrm{H}_{2} \mathrm{SO}_{4}$ signified that milder pretreatment conditions fails to remove an adequate amount of hemicelluloses from OPT. The higher the amount of remaining hemicelluloses upon pretreatment, the poorer would be the enzymatic digestibility of cellulose.

The approach of adopting organic acid pretreatment has attracted much attention among the researchers owing to its high potential to promote enzymatic saccharification of lignocellulosic biomass, as organic acids are much less hazardous and produce lesser inhibitory by-products of fermentation compared to other chemical pretreatments. Rattanaporn and co-workers (2018) employed organic acid (acetic acid, oxalic acid, and citric acid) pretreatment on OPT to investigate the effects of enzymatic saccharification and bioethanol production. Enzymatic hydrolysis was carried out for $72 \mathrm{~h}$ at $45^{\circ} \mathrm{C}$ using 20 FPU of Celluclast ${ }^{\circledR}$ and $100 \mathrm{CBU}$ of cellobiase along with $50 \mathrm{mM}$ sodium citrate buffer ( $\mathrm{pH} 4.7$ ) and $200 \mu \mathrm{L}$ of $2 \mathrm{M}$ sodium azide. The relationship between pretreatment parameters and pretreatment efficiency in terms of released reducing sugar yield was determined using response surface methodology (RSM) with Box-Behnken experimental design. Organic acid concentration, pretreatment temperature, and pretreatment time variables primarily affect the efficacy of chemical pretreatment of OPT. According to the mathematical models, optimum pretreatment conditions to attain the highest released sugar content for acetic acid was $107.3{ }^{\circ} \mathrm{C}, 30 \mathrm{~min}, 8.23 \mathrm{wt} \%$, for citric acid $\left(131.92{ }^{\circ} \mathrm{C}\right.$, $58.92 \mathrm{~min}, 13.92 \mathrm{wt} \%)$ and for oxalic acid $\left(100{ }^{\circ} \mathrm{C}, 60 \mathrm{~min}, 15 \mathrm{wt} . \%\right)$ in terms of pretreatment temperature, pretreatment time, and organic acid concentration, respectively. 
Response surface plots revealed the antagonistic effect of pretreatment parameters at a certain condition. Oxalic acid pretreated OPT biomass contained the highest amount of lignin upon enzymatic saccharification at $54.0 \%$, followed by citric acid (52.7\%) and acetic acid $(51.8 \%)$ pretreatments. This trend corroborated with the trend attained for released reducing sugar yield, signifying that oxalic acid was the most suitable pretreatment to improve the efficiency of enzymatic saccharification. As the lignin content inhibits the fermentation process, it may perhaps be speculated that citric acid pretreatment might form less amount of inhibitory by-products of fermentation. Analyses of OPT biomass composition upon pretreatment (prior to saccharification) revealed that untreated OPT contained the least cellulose content $(38.8 \%)$, followed by acetic acid (47.6\%), citric acid (49.6\%), and oxalic acid (52.1\%) pretreated OPT. Upon saccharification, hemicellulose and cellulose contents of pretreated OPT were reduced significantly even compared to untreated sample, validating its efficiency. Oxalic acid pretreatment yielded the highest enzymatic saccharification efficiency $(1.80 \mathrm{mg} / \mathrm{mL}$ reducing sugars $)$, followed by citric acid $(1.23 \mathrm{mg} / \mathrm{mL})$ and acetic acid $(1.0 \underline{3} \mathrm{mg} / \mathrm{mL})$ under optimal pretreatment conditions. Based on RSM, oxalic acid pretreated OPT released the maximum reducing sugar of 144 $\mathrm{mg} / \mathrm{g}$-pretreated biomass at the optimum condition. The effect of organic acid pretreatment in producing an improved ethanol yield was investigated by bioethanol fermentation of enzymatically hydrolyzed pretreated OPT using Saccharomyces cerevisiae TISTR 5606. The fermentation process was carried out in a batch at $32{ }^{\circ} \mathrm{C}$ for $60 \mathrm{~h}$. Citric acid pretreatment attained the highest ethanol yield $(16.27 \pm 1.03 \mathrm{~g} / \mathrm{L})$, followed by acetic acid $(13.69 \pm 0.84 \mathrm{~g} / \mathrm{L})$ and oxalic acid $(13.28 \pm 0.26 \mathrm{~g} / \mathrm{L})$. All three organic acid pretreated hydrolysates achieved a much higher ethanol production than the untreated OPT hydrolysate $(8.33 \pm 0.22 \mathrm{~g} / \mathrm{L})$. Even though citric acid produced the highest ethanol concentration, oxalic acid pretreatment was found to be the most effective in enhancing enzymatic saccharification of OPT. Thus, obtained data indicated that selecting a suitable organic acid to pretreat oil palm biomass is crucial in enhancing the saccharification efficiency and bioethanol fermentation production yield.

Removal of hemicellulose from oil palm biomass can be attained with the use of dilute acid pretreatment, which increases the accessibility of enzymes or microbes to cellulose in enhancing the biomass digestion.

\section{Alkali Pretreatment}

Alkali pretreatment is performed mainly by hydroxides such as $\mathrm{NaOH}, \mathrm{H}_{2} \mathrm{O}_{2}$, $\mathrm{NH}_{4} \mathrm{OH}$ (Ab Rahim et al. 2018), $\mathrm{KOH}$, and $\mathrm{Ca}(\mathrm{OH})_{2}$ (Ouyang et al. 2018). Potassium hydroxide can selectively remove xylene (Noorshamsiana et al. 2017), whereas $\mathrm{Ca}(\mathrm{OH})_{2}$ is inexpensive and safe to use. Alkaline pretreatment followed by acid pretreatment can produce more pure cellulose. In the alkaline pretreatment, a saponification reaction occurs in which the intermolecular ester linkage between hemicellulose and lignin is broken down. Therefore, the lignin is solubilized, and cellulose is easily exposed to enzymatic hydrolysis in the further steps (Sari et al. 2018).

There are advantages and disadvantages to alkaline pretreatment. It can be operated at low temperature and pressure, thus consuming less energy. It leads to cellulose swelling and reduces the crystallinity, consequently increasing the surface area for enzymatic reactions (Baruah et al. 2018). Moreover, alkaline pretreatment leads to lignin structural changes and removal of acetyl groups and uronic acid substitutes of the hemicellulose, thereby increasing carbohydrate accessibility to further enzymatic hydrolysis. Alkaline pretreatment is more effective in removing lignin. However, as a result of alkaline 
pretreatment, limited solubilization of hemicellulose is achieved and the process degrades less sugar (Kapoor et al. 2018). When $\mathrm{NH}_{3}$ is used for chemical pretreatment, it causes selective delignification and also can be recovered easily due to high volatility. Moreover, on an industrial scale, effective and easy recovery could indirectly reduce costs (Latif et al. 2018). However, alkaline pretreatment is only suitable for biomass with low lignin content.

Among the disadvantages of alkaline pretreatment, alkali salts can be converted to irrecoverable salts and may get absorbed by the biomass, making them difficult to recover (Noorshamsiana et al. 2017). Also, it requires a longer reaction time, and some hemicellulose is dissolved, which leads to loss of biomass. Alkaline pretreatment necessitates extensive washing and neutralizing before proceeding to further enzymatic hydrolysis (Kapoor et al. 2018).

Sodium hydroxide is the most widely used alkali pretreatment agent. According to Waluyo et al. (2018), lignin content decreased by $5.3 \%$ after being soaked in $15 \% \mathrm{NaOH}$ for $24 \mathrm{~h}$. In a similar study, Chavalparit et al. (2018) were able to reduce the lignin content by $10.2 \%$ by soaking OPEFB in $5 \% \mathrm{NaOH}$ for $48 \mathrm{~h}$. By comparing these two studies it may be concluded that, despite decreasing the concentration of $\mathrm{NaOH}$, the percentage of lignin removed can be increased by increasing the reaction time. In another study, Razali et al. (2018) were able to reduce the lignin content by $18.3 \%$. The pretreatment method they employed was soaking OPEFB in $2 \% \mathrm{NaOH}$ for $4 \mathrm{~h}$, followed by autoclaving at 121 ${ }^{\circ} \mathrm{C}$ for $5 \mathrm{~min}$. They were able to decrease the lignin content even further by applying heat and pressure, followed by the alkaline treatment. Similarly, studies performed using alkaline pretreatment and OPF as a raw material have demonstrated a high delignification percentage with high temperatures (Ahmad Sobri et al. 2019; Mahmood et al. 2019).

Kunasundari et al. (2017) pretreated sap from felled OPT using alkaline precipitation in view of enhancing the sugar fermentability for the efficient production of lactic acid. Their study aimed at fermentative lactic acid production under non-sterilized conditions through a novel Gram-positive bacterium Bacillus coagulans strain 191. This strain was used to ferment diverse sugars accompanied with yeast extract to form lactic acid. It is understood that alkaline precipitation is efficient in detoxifying a fermentative medium. They found out that alkaline pretreatment effectively removed fermentation inhibitors from the sap of OPT to achieve a high productivity of lactic acid. It was revealed that alkaline pretreatment (using $2 \mathrm{M} \mathrm{NaOH}$ ) carried out at higher $\mathrm{pH}$ (8 to 10) provided efficient fermentation by $B$. coagulans strain 191, which resulted in highly productive lactic acid yield. At $\mathrm{pH} 9$ and $24 \mathrm{~h}$ of fermentation, lactic acid reached the highest concentration at $63.3 \mathrm{~g} / \mathrm{L}$ and yield of $0.92 \mathrm{~g}$ per $\mathrm{g}$ of total sugars. In the absence of alkaline pretreatment, a lower lactic acid yield was obtained, attributed to the formation of inhibitory products. The screening of optimal temperature for the growth of strain 191 (incubation) was found to be $55^{\circ} \mathrm{C}$ for $72 \mathrm{~h}$, responsible for the production of highest yield of lactic acid. The yield of lactic acid and consumption of glucose reached 80 to $88 \%$ when the culture medium of strain 191 was sustained at $\mathrm{pH} 5.0$ to 6.0. For alkaline precipitation pretreatment, lowering the time duration of fermentation from $48 \mathrm{~h}$ to $24 \mathrm{~h}$ maximized the productivity of lactic acid from 0.89 to $2.64 \mathrm{~g} / \mathrm{L} / \mathrm{h}(\mathrm{h}=$ fermentation time). Interestingly, alkaline precipitation ( $\mathrm{pH} 8$ to 10) was able to detoxify inhibitory compounds in improving lactic acid fermentation by $B$. coagulans strain 191. It was revealed that the degradation of total sugars upon alkaline precipitation was not substantial (6.1 to 22\%). Although the total sugar degradation was not significant, alkaline precipitation method could be optimized to achieve an improved detoxification by altering the reaction conditions including reaction temperature and employing other alternate forms of alkali. 
Alkali pretreatment alters or removes lignin from the biomass to cleave lignincarbohydrate bonds in enhancing the accessible surface area and porosity in pretreated oil palm biomass. Thus, alkali pretreatment increases the digestion of cellulose to obtain a high sugar yield, which can be converted to value-added products.

\section{Organosolvent Pretreatment}

Organosolvents are organic solvents such as ethanol, methanol, acetone, glycerol, aqueous phenol, ethylene glycol, triethylene glycol, and aqueous n-butanol. These reactions are performed at temperatures between $150{ }^{\circ} \mathrm{C}$ and $200{ }^{\circ} \mathrm{C}$. In these reactions, these solvents increase the pore size of the biomass, which increases the accessibility of the biomass to further reactions. Also, internal bonds are hydrolyzed, which leads to disruption of the biomass. The use of acids or bases as catalysts increases the reaction rate (Kapoor et al. 2018).

The main advantage of this method is that solvents, such as ethanol, are inexpensive, can operate at low boiling points, and are less toxic. Furthermore, high-quality and low-molecular-weight lignin can be isolated from the organosolv process under mild conditions. However, organic solvents may be hazardous when handled in large quantities and are highly flammable. To prevent the precipitation of lignin before washing the biomass with water, it should be washed with organic solvents, which makes this process expensive (de Menezes Nogueira et al. 2019).

Organosolvent pretreatment with aqueous ethanol degraded $27.7 \%$ of lignin in a study by Mardawati et al. (2018). However, in another study, Chin et al. (2019) achieved greater delignification by using a catalyst concurrently with $50 \%$ aqueous ethanol. They used $\mathrm{NaOH}, \mathrm{H}_{2} \mathrm{SO}_{4}$, and $\mathrm{FeCl}_{3}$ as catalysts, separately. Of the catalysts used, $\mathrm{NaOH}$ yielded the greatest delignification $(67.2 \%)$.

Nurfahmi et al. (2016) investigated the effect of organosolvent pretreatment and acid hydrolysis process on OPEFB in producing bioethanol. Organosolvent pretreatment was carried out with the use of aqueous ethanol at varying concentration $(35,55$, and $75 \%$ vol), reaction temperature $\left(80,100\right.$, and $\left.120^{\circ} \mathrm{C}\right)$ and reaction time $(30,60$, and $90 \mathrm{~min})$. Organosolvent pretreatment is effective in unbounding the linkage between lignin and hemicellulose. Aqueous ethanol was employed in this study as the solvent owing to its low cost and ease of recovery. Their study demonstrated that increased ethanol concentration enhanced the degradation of lignin content, promoting cellulose and hemicellulose to able to convert into sugars through acid hydrolysis. Acid hydrolysis was performed at $1 \%(\mathrm{v} / \mathrm{v})$ $\mathrm{H}_{2} \mathrm{SO}_{4}$ at $90{ }^{\circ} \mathrm{C}$ with a reaction time $30 \mathrm{~min}$ to evaluate the influence of organosolvent pretreatment on overall sugar yield. Effect of pretreatment temperature at $35 \%$ vol. ethanol concentration depicted that heating temperature was positively correlated with overall sugar yield, in which 60 min of heating time attained the highest release of sugar from OPEFB. The optimal yield of overall sugar yield $(98.9 \mathrm{mg} / \mathrm{L})$ was obtained at $120{ }^{\circ} \mathrm{C}$ pretreatment temperature, $55 \%$ vol. ethanol concentration, together with 60 min reaction time. In terms of lignin content, higher pretreatment temperature resulted in lower lignin composition, which promotes delignification rate, thereby resulting in a higher sugar yield. Since hemicellulose degrades at around $180^{\circ} \mathrm{C}$, it is not advisable to heat treat at elevated temperatures. Moreover, pretreating for a longer time could dissolve a certain amount of hemicellulose, which lowers the total sugar yield. Pretreatment at 35\% and 55\% (v/v) ethanol concentration positively affected the sugar yield, conforming to the disruption of ether linkage between hemicellulose and lignin, enabling more cellulose and hemicellulose to convert into sugars. On the basis of acid hydrolysis on sugar yield, mild acid 
concentration appears to be the suitable choice to mitigate the formation of hydrolysis inhibitory compounds (including furfural, HMF, formic acid and acetic acid), thereby increasing the bioethanol yield.

\section{Deep Eutectic Solvents / Low-transition-temperature Mixture Pretreatment}

One of the main complications in pretreatment methods is their ineffectiveness in removing lignin due to their low solubility. Consequently, researchers have shifted their interest toward the applicability of deep eutectic solvents (also known as low-transitiontemperature mixtures), which are novel, eco-friendly solvents (green solvents). Because deep eutectic solvents share similar physicochemical properties with ionic liquids, these promising green solvents have recently gained widespread scientific interest for the pretreatment of lignocellulosic biomass (Thi and Lee 2019). Despite their similar physicochemical properties, a deep eutectic solvent costs $80 \%$ less than a similarly effective ionic liquid, which has been a deciding factor for the replacement of ionic liquids with deep eutectic solvents. Furthermore, deep eutectic solvents considerably enhance the enzymatic hydrolysis performance of the pretreated oil palm biomass (Tajuddin et al. 2019).

Deep eutectic solvents are a new generation of green solvents that can overcome the significant drawbacks of ionic liquids due to being cost-effective, biodegradable, ecofriendly, easy to synthesize, and reusable (Yiin et al. 2018a). They are ionic fluids of two or three compounds linked through hydrogen bonds, forming a eutectic mixture that has a melting point lower than any of its components. Generally obtained by mixing quaternary ammonium salts with metal salts, they are capable of forming bonds with complex halide ions (Satlewal et al. 2018). They are biodegradable but require specialized knowledge to handle and synthesize. In a study by Thi and Lee (2019), a maximum reducing sugar yield of $20.7 \%$ was achieved using choline chloride and lactic acid (1:2 molar ratio) as the lowtransition-temperature mixture. Attaining a high glucose yield is attributed to the severe disruption of lignin and hemicellulose in OPEFB biomass, as illustrated by SEM and FTIR analyses. Degradation of lignin and removal of hemicellulose exposes the cellulose content to enzymatic hydrolysis. The study highlighted that (choline chloride: lactic acid) deep eutectic solvent pretreatment is more effective compared to alkali and acid pretreatments in terms of mitigating sugar loss, economic viability, and eco-friendliness. Tan et al. (2018) observed a maximum delignification of $88 \%$ using a choline chloride and lactic acid lowtransition-temperature mixture. Therefore, the above studies imply that a low-transitiontemperature mixture of choline chloride and lactic acid is effective for greater reducing sugar yield and delignification.

Zulkefli et al. (2017) applied deep eutectic solvent (DES) pretreatment on OPT to optimize its enzymatic hydrolysis. The study utilized choline chloride and ethylammonium chloride ammonium salts, and hydrogen bond donor solvents of glycerol, ethylene glycol and urea to prepare DESs with 1:2 molar ratio of ammonium salt: hydrogen bond donor. Ethylammonium chloride: ethylene glycol (1:2) deep eutectic solvent imparted the highest efficacy on OPT pretreatment among all the tested DESs. Applying the most suited DES heated at $100{ }^{\circ} \mathrm{C}$ for $48 \mathrm{~h}$ resulted in the highest OPT biomass dissolution (58\%) with the removal of $83 \%$ of hemicellulose and $42 \%$ of lignin. FTIR analysis revealed that ethylammonium chloride: ethylene glycol (1:2) DES rendered the most pronounced structural alterations in OPT, signifying the highest delignification (corresponds to a greater hydroxyl bond disruption) as opposed to other DESs. Moreover, ethylammonium chloride: ethylene glycol pretreatment medium attained the optimum glucose conversion 
of $74 \%\left(50{ }^{\circ} \mathrm{C}\right.$ for $\left.24 \mathrm{~h}\right)$ with $50 \mathrm{FPU} / \mathrm{g}$ of Celluclast and $100 \mathrm{CBU} / \mathrm{mL}$ of Novozyme 188. Removal of hemicellulose through DES pretreatment exposes cellulose, thus allowing enzymes to reach its reaction sites. It is vital to effectively remove hemicellulose and lignin in the biomass structure in order to provide ease of access for the enzymes to cellulose. Higher degradation of hemicellulose is due to its less thermodynamic stability as opposed to both lignin and cellulose, which allows DESs to easily solubilize hemicellulose.

\section{Ionic Liquids}

Ionic liquids (IL) are molten salts with a melting point less than $100{ }^{\circ} \mathrm{C}$ (Ahmad et al. 2018c). They are exploited as solvents and/or co-solvents and have potential for the pretreatment of lignocellulosic biomass due to being eco-friendly and recyclable in comparison to volatile organic compounds. Ionic liquids contain an organic cation, which can be imidazolium, pyridinium, aliphatic ammonium, alkylated phosphonium, or sulfonium, along with an organic or inorganic anion (Moniruzzaman and Goto 2018). Ionic liquids can undergo a wide range of intermolecular interactions with lignocellulosic biomass under mild processing conditions with relatively low energy input, fulfilling a crucial requirement for sustainable processing of lignocelluloses to generate biofuels and value-added chemicals. They are safe and non-toxic (i.e., green solvents) and possess low volatility, substantial thermal stability (Ahmad et al. 2018c), high solvating power, and high chemical stability (Mahmood et al. 2018; Rashid et al. 2018).

Ionic liquids can promote biomass decrystallization by disrupting the hydrogen bond linkages between the cellulose microfibers, which improves digestibility of the biomass, enhances surface area and porosity (Abraham et al. 2020). They can dissolve cellulose, though the dissolving properties depend on the cation used (Azizan et al. 2019). As the length of the alkyl chain increases, the solubility of cellulose progressively decreases. Dissolution of cellulose increases in the presence of electron-withdrawing groups in the alkyl chains of IL cations (Baruah et al. 2018). Although these liquids can be recycled, the process is costly, and they are toxic to microorganisms and enzymes used in the further hydrolysis steps. Mahmood et al. (2018) reported that ionic liquid pretreatment, using 1-butyl-3-methylimidazolium chloride ([BMIM][Cl]) and 1-ethyl-3-methylimidazolium acetate ([EMIM][OAc]), of OPF at high solids loading improved the thermal stability and altered the chemical composition by partially removing hemicellulose and lignin impurities, even though it did not increase the crystallinity of the OPF.

Mahmood et al. (2019) pretreated crude oil palm biomass using [BMIM][Cl] and 1-ethyl-3-methylimidazolium diethyl phosphate ([EMIM][DEP]) ionic liquids and discovered an increase in the cellulosic content of the crude oil palm biomass and an improvement in its thermal stability. The ionic-liquid-pretreated crude oil palm biomass demonstrated a high entropy change $(\Delta S)(-194.7$, and $-196.7 \mathrm{~J} / \mathrm{mol}$ for [BMIM][Cl] and ([EMIM][DEP]), respectively), suggesting a more disordered lignocellulosic structure, which showcases imidazolium-based ILs' ability to break down its structure. The study highlighted that ILs utilized provide greater delignification ability of oil palm biomass compared to acid, alkali and liquid hot water pretreatment methods. IL pretreatment improved the cellulosic fraction of oil palm biomass, which in turn increased its thermal stability. Imidazolium-based IL pretreatment not only opens up the complex oil palm biomass structure, but it also activates and improves the degrees of freedom of rotation and vibration of the structure compared to untreated OPB samples. [BMIM][Cl] and [EMIM][DEP] pretreated OPB resulted in higher $\Delta G^{\circ}$ values $(208.0 \mathrm{~kJ} / \mathrm{mol}$ and 210.9 $\mathrm{kJ} / \mathrm{mol}$, respectively) compared to untreated OPB (188.9 kJ/mol), suggesting that IL 
pretreatment could have shifted OPB samples to a higher energy state compared to its thermodynamic equilibrium, providing more thermodynamic stability. Obtaining higher $\Delta H^{\circ}$ values for IL pretreated OPB necessitates higher thermal energy for their degradation compared to untreated $\mathrm{OPB}$. Increased $\Delta H^{\circ}$ values attribute to an increment in cellulosic content and a reduction in the crystallinity of IL-pretreated OPB fibers. Their findings indicated the potential applicability of ionic liquids in agriculture for the pretreatment of lignocellulosic biomass wastes to generate biofuels with an environmentally benign technique.

Of all ionic liquid pretreatment agents, those with acetate are among the most widely studied. Abu Darim et al. (2018), Azmi et al. (2018), and Mahmood et al. (2018) studied the use of ([EMIM][OAc]) in different ratios with OPF and different reaction temperatures. They reported that lignin content and crystallinity index decreased by a reasonable amount. Elgharbawy et al. (2018) demonstrated that choline acetate is more effective in delignification than choline butanoate.

Typically, enzymes obtained from naturally occurring fungi, or enzymes formed through genetically engineered fungi are utilized for enzymatic delignification to be employed in aqueous media. Nevertheless, degradation of lignin in aqueous media proceed quite slowly, which can be attributed to ineffective enzyme approachability to the biomass surface to degrade lignin. Thus, researchers have overcome this issue with the use of ionic liquid pretreatment before carrying out enzymatic delignification. For instance, Financie and co-workers (2016) applied the ionic liquids [EMIM][DEP] and [EMIM][OAC] for pretreatment at different temperatures $\left(70\right.$ to $100{ }^{\circ} \mathrm{C}$ for $\left.4 \mathrm{~h}\right)$ prior to enzymatic delignification of OPF to achieve an enhanced enzymatic delignification efficiency. [EMIM][DEP] was chosen as the most suited IL due to its low viscosity and excellent hydrogen bonding acceptor capability, which in turn provides superior ability to dissolve OPF fibers (Elgharbawy et al. 2016). Moreover, they investigated the effect of IL pretreatment temperature and time on OPF and found that upon pretreatment, OPF resulted in a noticeably lower lignin content as opposed to untreated OPF. OPF pretreated with [EMIM][DEP] at $100{ }^{\circ} \mathrm{C}$ for $4 \mathrm{~h}$ achieved the highest delignification at $68.8 \%$, followed by $90{ }^{\circ} \mathrm{C}$ for $4 \mathrm{~h}(\mathrm{ca} .45 .8 \%)$. Elgharbawy et al. (2016) in their review paper noted that pretreatment temperature plays an important role in affecting the yield of reducing sugars released from lignocellulosic biomass, which in turn influences the valorization of lignocellulosic biomass into biofuels. Nevertheless, OPF pretreated at $100{ }^{\circ} \mathrm{C}$ showed a lower holocellulose content in comparison to $90{ }^{\circ} \mathrm{C}$ pretreatment owing to the degradation of cellulose and hemicellulose at higher pretreatment temperature. Thus, $90{ }^{\circ} \mathrm{C}$ and $4 \mathrm{~h}$ pretreatment condition was selected for consequent enzymatic hydrolysis to result in OPF with high cellulose content.

Financie and co-workers (2016) attained OPF samples rich in cellulose, corroborating to a high thermal stability in comparison to the untreated OPF. Derivative thermogravimetric (DTG) analysis revealed that OPF pretreated with [EMIM][DEP] ionic liquid at $90{ }^{\circ} \mathrm{C}$ for $4 \mathrm{~h}$ recorded a maximum degradation temperature $\left(T_{\max }\right)$ of $357.9^{\circ} \mathrm{C}$, while untreated OPF showed a $T_{\max }$ of $331.2^{\circ} \mathrm{C}$. According to previous studies (Zhang et al. 2014; Financie et al. 2016; Mahmood et al. 2016; Mohtar et al. 2017; Liu et al. 2020), increased thermal stability of ionic liquid pretreated lignocellulosic biomass justifies an increased delignification and cellulosic content, and a reduction in hemicellulose content. Enzymatic hydrolysis was carried out with laccase as an enzyme in sodium acetate buffer $(\mathrm{pH} 4.5)$ at $50{ }^{\circ} \mathrm{C}$ for $24 \mathrm{~h}$. IL pretreatment with subsequent enzymatic delignification resulted in an $\alpha$-cellulose content of $68.1 \mathrm{wt} \%$ (up from $45.7 \%$ ), whereas hemicellulose 
and lignin content was reduced to $12.1 \%$ and $8.5 \%$ (weight $\%$ ), respectively. It was noted that enhanced delignification efficiency can be attributed to the ease of enzyme access to the swollen OPF pretreated with the ionic liquid, which opens up more accessible surface area for enzymes. The study explicitly suggested that combining ionic liquid pretreatment followed by enzymatic hydrolysis could deliver a platform to valorize OPF into bioenergy and biomaterials (biocomposites and textiles).

\section{Ozonolysis}

Ozonolysis is a chemical pretreatment method that employs ozone and mild operating conditions, offering high specificity in the delignification process (Perrone $e$ t al. 2018). In these types of reactions, the amount of water present in the biomass is a crucial factor that controls the reaction. Ozonolysis can be performed at ambient temperature and pressure; more importantly, it does not produce inhibitory compounds (Kapoor et al. 2018). Ozone has a short half-life and can decompose quickly, and it is also a corrosion hazard. Thus, it is not suitable for long-distance transportation and is typically generated on-site for use in ozonolysis. Another downside of ozonolysis is that ozone production requires high energy input (Rahman and Amin 2019).

Omar and Amin (2016) studied the multi-response optimization of OPF pretreatment by ozonolysis. It was discovered that ozonolysis pretreatment on OPF was effective in lignin degradation (up to $84.9 \%$ ) and enhanced total reducing sugar recovery (up to $99.9 \%$ ). The effect of particle size of OPF, reaction time, flowrate of ozone, moisture content variables along with their influence on degradation of lignin and total reducing sugar recovery were investigated by response surface methodology (RSM) based on BoxBehnken experimental design. RSM results revealed that during the ozonolysis process, moisture content-reaction time interaction imparted the biggest influence on total reducing sugar recovery, whereas particle size-moisture interaction influenced primarily on lignin degradation. Moreover, it was revealed that bigger particle size of OPF improved both the degradation of lignin and the total reducing sugar recovery. The multi-response optimization for optimum lignin degradation and the total reducing sugar recovery was achieved employing the desirability function (represented by the desirability profiles). Based on the desirability profiles, the optimal conditions for total reducing sugar recovery and degradation of lignin were; $75 \mathrm{~min}$ of reaction time, $0.8 \mathrm{~mm}$ of particle size, 105 $\mathrm{mL} / \mathrm{min}$ of ozone flowrate, and $40 \mathrm{wt} \%$ of moisture content obtained through $19.5 \%$ of ozone consumption. They achieved a comparable levulinic acid (initial chemical to produce ethyl levulinate and $\gamma$-valerolactone for commercial applications) yield to that of commercial cellulose through ozonolysis-pretreated OPF, affirming an effective lignin degradation. Thus, the authors suggested that their study could aid future studies in improving the effectiveness of biorefinery processes.

Mardawati et al. (2019) performed a similar study on optimization of moisture content, particle size, and reaction time of OPEFB through ozonolysis pretreatment. They aimed to assess the effectiveness of ozone for the delignification of OPEFB by studying the effect of 30, 40, and 50\% moisture content, 20, 40, and 60 mesh particle size, and 30, 45, and 60 min reaction time as well as their relationship with lignin degradation, reducing sugar yield, and holocellulose content, evaluated through RSM based on Box Behnken. They found out that the optimum conditions to attain an efficient lignin and hemicellulose degradation upon ozonolysis were; $50 \%$ moisture content, 40 mesh particle size, and a reaction time of $30 \mathrm{~min}$. The data obtained revealed that ozonolysis was effective in delignifying lignin up to $63.9 \%$, gaining a cellulose content of up to $41.0 \%$ and a reducing 
sugar yield up to $0.59 \mathrm{~g} / \mathrm{L}$. Thus, ozonolysis pretreatment reduced the lignin and hemicellulose content of OPEFB without reducing the cellulose content. In the absence of ozonolysis pretreatment, OPEFB hydrolysate produced a reducing sugar yield of mere 0.08 $\mathrm{g} / \mathrm{L}$, signifying the importance of an effective pretreatment such as ozonolysis to improve enzymatic hydrolysis. It was observed that a combined increment in moisture content $(50 \%)$ and reaction time of ozonolysis $(60 \mathrm{~min})$ at 40 mesh particle size increased the reducing sugar yield $(0.59 \mathrm{~g} / \mathrm{L})$ in comparison to reducing both the moisture content $(30 \%)$ and reaction time $(30 \mathrm{~min})$ at 40 mesh particle size, which achieved a reducing sugar concentration of $0.33 \mathrm{~g} / \mathrm{L}$. Pertaining to the effect on cellulose content, 20 to 40 mesh particle size of OPEFB increased the cellulose content in comparison to 60 mesh particle size.

Table 2. Overview of Various Chemical Pretreatment Methods Employed on Oil Palm Biomass and Their Potential Applications

\begin{tabular}{|c|c|c|c|c|c|c|}
\hline $\begin{array}{l}\text { Pretreatment } \\
\text { Method }\end{array}$ & $\begin{array}{l}\text { Major Agents } \\
\text { Used }\end{array}$ & Conditions & $\begin{array}{l}\text { Oil Palm } \\
\text { Biomass }\end{array}$ & $\begin{array}{l}\text { Concluding } \\
\text { Remarks }\end{array}$ & $\begin{array}{l}\text { Potential } \\
\text { Application }\end{array}$ & Reference \\
\hline \multirow[t]{9}{*}{$\begin{array}{c}\text { Acid } \\
\text { pretreatment }\end{array}$} & $\begin{array}{c}5 \%(\mathrm{~m} / \mathrm{v}) \\
\mathrm{H}_{2} \mathrm{SO}_{4}\end{array}$ & $\begin{array}{c}121^{\circ} \mathrm{C}, \\
0.101 \\
\mathrm{MPa}, 60 \\
\min \end{array}$ & OPMF & $\begin{array}{c}\text { Removal of } \\
88.4 \% \text { of } \\
\text { hemicellulose }\end{array}$ & $\begin{array}{l}\text { Production } \\
\text { of ethanol }\end{array}$ & $\begin{array}{c}\text { Brito et al. } \\
(2018)\end{array}$ \\
\hline & 6 vol\% $\mathrm{H}_{2} \mathrm{SO}_{4}$ & $\begin{array}{c}120^{\circ} \mathrm{C} \\
0.9 \\
\mathrm{MPa}, 60 \\
\min \end{array}$ & OPEFB & $\begin{array}{c}\text { Obtained a } \\
\text { sugar } \\
\text { concentration } \\
\text { of } 28.3 \mathrm{~g} / \mathrm{L}\end{array}$ & $\begin{array}{l}\text { Production of } \\
\text { biohydrogen }\end{array}$ & $\begin{array}{c}\text { Gonzales } \\
\text { et al. } \\
\text { (2019) }\end{array}$ \\
\hline & $\begin{array}{c}3.77 \text { vol\% } \\
\mathrm{H}_{2} \mathrm{SO}_{4}\end{array}$ & $\begin{array}{c}119^{\circ} \mathrm{C} \\
68.97 \\
\min \end{array}$ & OPEFB & $\begin{array}{c}32.5 \% \\
\text { enzymatic } \\
\text { digestibility }\end{array}$ & $\begin{array}{l}\text { Production } \\
\text { of xylose }\end{array}$ & $\begin{array}{c}\text { Thamsee } \\
\text { et al. } \\
\text { (2018) }\end{array}$ \\
\hline & 2 vol\% $\mathrm{HNO}_{3}$ & $\begin{array}{c}121^{\circ} \mathrm{C} \\
0.103 \\
\mathrm{MPa}, 5 \\
\min \end{array}$ & OPEFB & $\begin{array}{l}56.7 \% \text { lignin } \\
\text { removal }\end{array}$ & $\begin{array}{l}\text { Production of } \\
\text { reducing } \\
\text { sugars }\end{array}$ & $\begin{array}{l}\text { Kamsani et } \\
\text { al. (2018) }\end{array}$ \\
\hline & $\begin{array}{c}2.5 \mathrm{wt} \% \text { acetic } \\
\text { acid }\end{array}$ & $\begin{array}{c}120.2 \\
{ }^{\circ} \mathrm{C}, 0.1 \\
\mathrm{MPa}, 15 \\
\min \end{array}$ & OPEFB & $\begin{array}{c}13 \% \text { total } \\
\text { xylose } \\
\text { recovery from } \\
\text { hemicellulose }\end{array}$ & $\begin{array}{c}\text { Production } \\
\text { of xylitol }\end{array}$ & $\begin{array}{l}\text { Harahap } \\
\text { and } \\
\text { Kresnowati } \\
(2018)\end{array}$ \\
\hline & $\begin{array}{c}1.82 \mathrm{wt} \% \\
\mathrm{H}_{2} \mathrm{SO}_{4}\end{array}$ & $\begin{array}{l}140^{\circ} \mathrm{C}, \\
20 \mathrm{~min}, \\
400 \mathrm{rpm}\end{array}$ & OPF & $\begin{array}{c}23 \% \\
\text { delignification }\end{array}$ & - & $\begin{array}{l}\text { Mahmood } \\
\text { et al. } \\
\text { (2019) }\end{array}$ \\
\hline & $\begin{array}{c}10 \text { wt } \% \text { acetic } \\
\text { acid }\end{array}$ & $\begin{array}{l}100^{\circ} \mathrm{C} \\
30 \mathrm{~min}\end{array}$ & OPT & $\begin{array}{c}\text { Released } \\
1.13 \mathrm{mg} / \mathrm{mL} \text { of } \\
\text { reducing } \\
\text { sugars }\end{array}$ & \multirow{3}{*}{$\begin{array}{l}\text { Production } \\
\text { of bioethanol }\end{array}$} & \multirow{3}{*}{$\begin{array}{l}\text { Rattanaporn } \\
\text { et al. (2018) }\end{array}$} \\
\hline & $\begin{array}{c}15 \mathrm{wt} \% \\
\text { oxalic acid }\end{array}$ & $\begin{array}{l}140^{\circ} \mathrm{C}, \\
45 \mathrm{~min}\end{array}$ & OPT & $\begin{array}{l}\text { Released } \\
1.85 \mathrm{mg} / \mathrm{mL} \\
\text { of reducing } \\
\text { sugars }\end{array}$ & & \\
\hline & $\begin{array}{c}15 \text { wt\% } \\
\text { citric acid }\end{array}$ & $\begin{array}{l}140^{\circ} \mathrm{C} \\
45 \mathrm{~min}\end{array}$ & OPT & $\begin{array}{c}\text { Released } \\
1.20 \mathrm{mg} / \mathrm{mL} \\
\text { of reducing } \\
\text { sugars }\end{array}$ & & \\
\hline
\end{tabular}




\begin{tabular}{|c|c|c|c|c|c|c|}
\hline \multirow[t]{12}{*}{$\begin{array}{c}\text { Alkaline } \\
\text { pretreatment }\end{array}$} & $\begin{array}{c}2 \%(w / v) \\
\mathrm{KOH}\end{array}$ & $\begin{array}{c}120^{\circ} \mathrm{C} \\
3 \mathrm{~h}\end{array}$ & OPEFB & $\begin{array}{l}36.7 \% \text { lignin } \\
\text { removal }\end{array}$ & $\begin{array}{l}\text { Production of } \\
\text { vanillic acid } \\
\text { and biovanillin }\end{array}$ & $\begin{array}{c}\text { Zulkarnain } \\
\text { et al. } \\
\text { (2018) }\end{array}$ \\
\hline & $\begin{array}{c}12 \%(\mathrm{w} / \mathrm{v}) \\
\mathrm{NaOH}\end{array}$ & $\begin{array}{c}20^{\circ} \mathrm{C}, 1 \\
\text { atm, } 24 \\
h\end{array}$ & OPEFB & $\begin{array}{l}13.8 \% \text { lignin } \\
\text { removal }\end{array}$ & - & $\begin{array}{l}\text { Waluyo et } \\
\text { al. (2018) }\end{array}$ \\
\hline & $\begin{array}{c}5 \%(w / v) \\
\mathrm{NaOH}\end{array}$ & $\begin{array}{c}20^{\circ} \mathrm{C}, 1 \\
\text { atm, } 48 \\
h\end{array}$ & OPEFB & $\begin{array}{l}41.0 \% \text { lignin } \\
\text { removal }\end{array}$ & $\begin{array}{l}\text { Production } \\
\text { of biogas }\end{array}$ & $\begin{array}{c}\text { Chavalparit et } \\
\text { al. (2018) }\end{array}$ \\
\hline & $0.5 \mathrm{~N} \mathrm{NaOH}$ & $\begin{array}{c}121^{\circ} \mathrm{C}, \\
0.1 \\
\mathrm{MPa}, 75 \\
\min \end{array}$ & OPEFB & $\begin{array}{l}57.1 \% \text { lignin } \\
\text { removal }\end{array}$ & $\begin{array}{c}\text { Production } \\
\text { of } \\
\text { biohydrogen }\end{array}$ & $\begin{array}{l}\text { Sari et al. } \\
(2018)\end{array}$ \\
\hline & $3 \mathrm{wt} \% \mathrm{NaOH}$ & $\begin{array}{c}137.15 \\
{ }^{\circ} \mathrm{C}, \\
109.63 \\
\mathrm{~min}, \\
500 \mathrm{rpm}\end{array}$ & OPEFB & $\begin{array}{c}63 \% \text { lignin } \\
\text { removal }\end{array}$ & - & $\begin{array}{l}\text { Zawawi et } \\
\text { al. (2018) }\end{array}$ \\
\hline & $5.5 \mathrm{wt} \% \mathrm{NaOH}$ & $\begin{array}{l}200^{\circ} \mathrm{C}, \\
60 \mathrm{~min}, \\
500 \mathrm{rpm}\end{array}$ & OPEFB & $\begin{array}{l}74.5 \% \text { lignin } \\
\text { removal }\end{array}$ & - & $\begin{array}{l}\text { Sebran et } \\
\text { al. (2018) }\end{array}$ \\
\hline & $1 \mathrm{M} \mathrm{NaOH}$ & $\begin{array}{l}121^{\circ} \mathrm{C}, \\
60 \mathrm{~min}\end{array}$ & OPEFB & $\begin{array}{l}55.4 \% \text { lignin } \\
\text { removal }\end{array}$ & $\begin{array}{l}\text { Production } \\
\text { of bioethanol }\end{array}$ & Kim (2018) \\
\hline & $\begin{array}{c}2 \%(w / v) \\
\mathrm{NaOH}\end{array}$ & $\begin{array}{c}121^{\circ} \mathrm{C}, \\
5 \mathrm{~min}\end{array}$ & OPEFB & $\begin{array}{l}58.3 \% \text { lignin } \\
\text { removal }\end{array}$ & $\begin{array}{l}\text { Production } \\
\text { of biobutanol }\end{array}$ & $\begin{array}{l}\text { Razali et } \\
\text { al. (2018) }\end{array}$ \\
\hline & $5 \mathrm{M} \mathrm{NH}_{4} \mathrm{OH}$ & $\begin{array}{c}20^{\circ} \mathrm{C}, 1 \\
\text { atm, } 24 \\
\mathrm{~h}\end{array}$ & OPEFB & $\begin{array}{c}31 \% \text { lignin } \\
\text { removal }\end{array}$ & $\begin{array}{c}\text { Production of } \\
\text { bioethanol }\end{array}$ & $\begin{array}{l}\text { Mardawati } \\
\text { et al. } \\
(2019)\end{array}$ \\
\hline & $5 \mathrm{wt} \% \mathrm{NH}_{3}$ & $\begin{array}{c}120.2 \\
{ }^{\circ} \mathrm{C}, 0.1 \\
\mathrm{MPa}, 15 \\
\min \end{array}$ & OPEFB & $\begin{array}{l}19.2 \% \text { xylose } \\
\text { recovery from } \\
\text { hemicellulose }\end{array}$ & $\begin{array}{c}\text { Production of } \\
\text { xylitol }\end{array}$ & $\begin{array}{l}\text { Harahap } \\
\text { and } \\
\text { Kresnowati } \\
(2018)\end{array}$ \\
\hline & $\begin{array}{c}6 \%(\mathrm{w} / \mathrm{v}) \\
\mathrm{NaOH}\end{array}$ & $\begin{array}{l}100^{\circ} \mathrm{C} \\
60 \mathrm{~min}\end{array}$ & OPF & $\begin{array}{l}84 \% \text { lignin } \\
\text { removal }\end{array}$ & $\begin{array}{l}\text { Xylan } \\
\text { recovery in } \\
\text { black liquor }\end{array}$ & $\begin{array}{c}\text { Ahmad } \\
\text { Sobri et al. } \\
(2019)\end{array}$ \\
\hline & $\begin{array}{c}3 \%(w / v) \\
\mathrm{NaOH}\end{array}$ & $\begin{array}{l}121^{\circ} \mathrm{C}, \\
20 \mathrm{~min}\end{array}$ & OPF & $\begin{array}{l}5.11 \% \text { lignin } \\
\text { removal }\end{array}$ & $\begin{array}{l}\text { Production } \\
\text { of } 2,3- \\
\text { butanediol }\end{array}$ & $\begin{array}{l}\text { Hazeena } \\
\text { et al. } \\
\text { (2019) }\end{array}$ \\
\hline
\end{tabular}




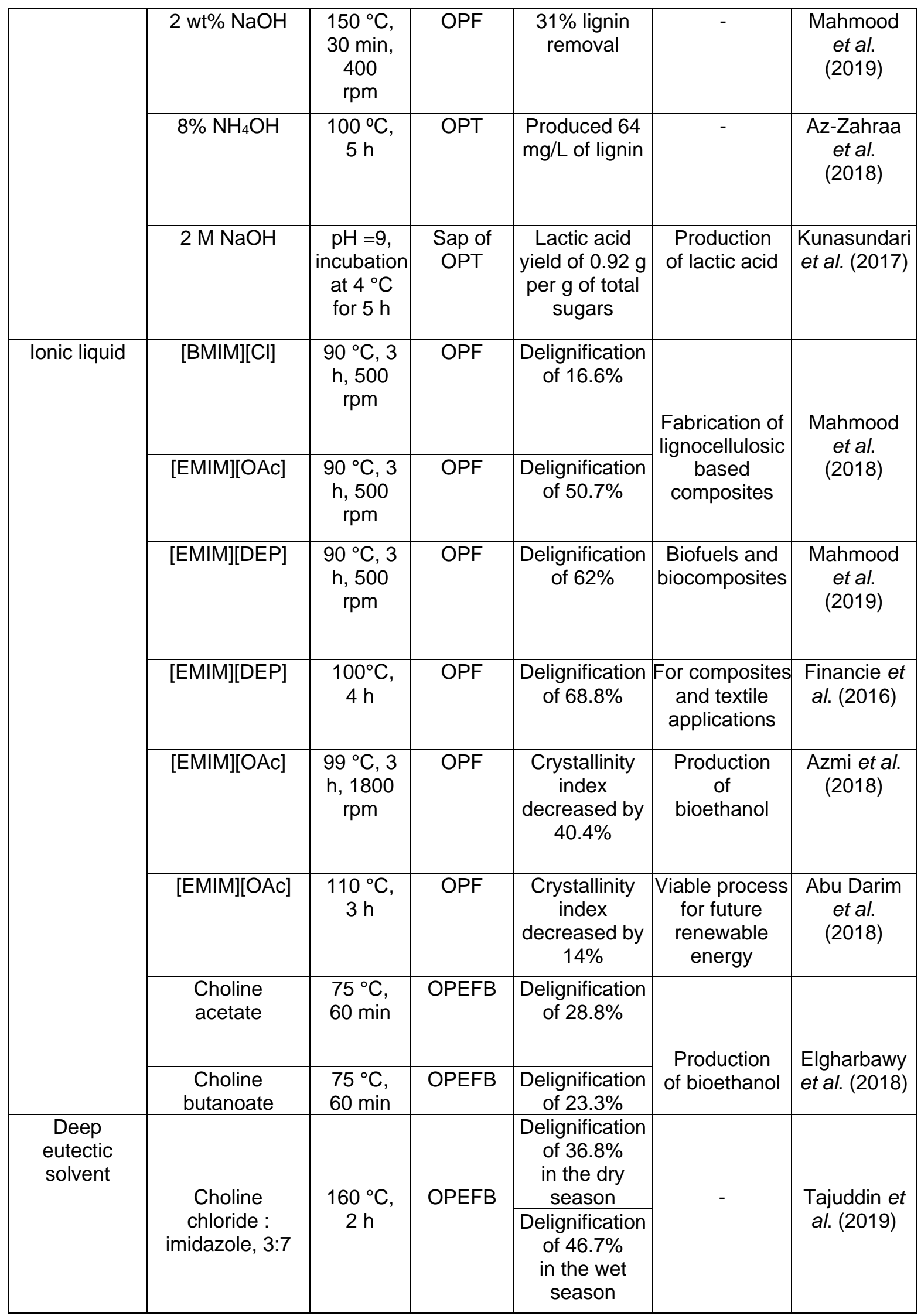




\begin{tabular}{|c|c|c|c|c|c|}
\hline $\begin{array}{c}\text { Choline } \\
\text { chloride : lactic } \\
\text { acid, } 1: 2\end{array}$ & $\begin{array}{c}120^{\circ} \mathrm{C} \\
3 \mathrm{~h}\end{array}$ & OPEFB & $\begin{array}{c}\text { Reducing } \\
\text { sugars yield: } \\
20.7 \%\end{array}$ & \multirow{3}{*}{ - } & \multirow{3}{*}{$\begin{array}{c}\text { Thi and } \\
\text { Lee (2019) }\end{array}$} \\
\hline $\begin{array}{c}\text { Choline } \\
\text { chloride : urea, } \\
1: 2\end{array}$ & $\begin{array}{c}120^{\circ} \mathrm{C}, \\
3 \mathrm{~h}\end{array}$ & OPEFB & $\begin{array}{c}\text { Reducing } \\
\text { sugars yield: } \\
16.9 \%\end{array}$ & & \\
\hline $\begin{array}{c}\text { Choline } \\
\text { chloride : } \\
\text { glycerol, } 1: 2\end{array}$ & $\begin{array}{c}120^{\circ} \mathrm{C}, \\
3 \mathrm{~h}\end{array}$ & OPEFB & $\begin{array}{c}\text { Reducing } \\
\text { sugars yield: } \\
20.0 \%\end{array}$ & & \\
\hline $\begin{array}{c}\text { Choline } \\
\text { chloride : lactic } \\
\text { acid, 1:5 }\end{array}$ & $\begin{array}{c}120^{\circ} \mathrm{C} \\
8 \mathrm{~h}\end{array}$ & OPEFB & $\begin{array}{c}\text { Delignification } \\
\text { of } 88 \%\end{array}$ & \multirow[b]{2}{*}{$\begin{array}{l}\text { Processing } \\
\text { of biomass }\end{array}$} & \multirow[b]{2}{*}{$\begin{array}{l}\text { Tan et al. } \\
\text { (2018) }\end{array}$} \\
\hline $\begin{array}{l}\mathrm{D}(+) \text {-glucose : } \\
\text { lactic acid, 1:5 }\end{array}$ & $\begin{array}{c}120^{\circ} \mathrm{C} \\
8 \mathrm{~h}\end{array}$ & OPEFB & $\begin{array}{c}\text { Delignification } \\
\text { of } 55 \%\end{array}$ & & \\
\hline $\begin{array}{c}\mathrm{K}_{2} \mathrm{CO}_{3}: \text { glycerol, } \\
1: 6\end{array}$ & $\begin{array}{c}120^{\circ} \mathrm{C}, \\
8 \mathrm{~h}\end{array}$ & OPEFB & $\begin{array}{l}\text { Delignification } \\
\text { of } 51 \%\end{array}$ & \multirow[b]{2}{*}{ - } & \multirow{2}{*}{$\begin{array}{l}\text { New et al. } \\
(2019)\end{array}$} \\
\hline $\begin{array}{c}\text { Choline } \\
\text { chloride : urea, } \\
1: 2\end{array}$ & $\begin{array}{c}120^{\circ} \mathrm{C}, \\
4 \mathrm{~h}\end{array}$ & OPF & $\begin{array}{c}\text { Delignification } \\
\text { of } 16.3 \%\end{array}$ & & \\
\hline $\begin{array}{c}\text { L-malic acid: } \\
\text { monosodium } \\
\text { glutamate : } \\
\text { water, } \\
3: 1: 5\end{array}$ & $\begin{array}{c}100^{\circ} \mathrm{C}, \\
24 \mathrm{~h}\end{array}$ & OPEFB & $\begin{array}{l}13.9 \% \text { lignin } \\
\text { removal }\end{array}$ & $\begin{array}{l}\text { Biomass } \\
\text { refinery } \\
\text { processes }\end{array}$ & $\begin{array}{l}\text { Yiin et al. } \\
\text { (2018b) }\end{array}$ \\
\hline $\begin{array}{c}\text { L-malic acid: } \\
\text { monosodium } \\
\text { glutamate : } \\
\text { water, } \\
3: 1: 5\end{array}$ & $\begin{array}{l}80^{\circ} \mathrm{C} \\
24 \mathrm{~h}\end{array}$ & OPEFB & $\begin{array}{c}9.97 \% \\
\text { volatile mass } \\
\text { loss of lignin }\end{array}$ & \multirow{2}{*}{$\begin{array}{l}\text { Production of } \\
\text { pyrolysis oil }\end{array}$} & \multirow[b]{2}{*}{$\begin{array}{l}\text { Yiin et al. } \\
\text { (2018a) }\end{array}$} \\
\hline $\begin{array}{c}\text { L-malic acid: } \\
\text { choline } \\
\text { chloride : } \\
\text { water, } 2: 4: 2\end{array}$ & $\begin{array}{c}80^{\circ} \mathrm{C} \\
18 \mathrm{~h}\end{array}$ & OPEFB & $\begin{array}{c}11.1 \% \\
\text { volatile mass } \\
\text { loss of lignin }\end{array}$ & & \\
\hline $\begin{array}{c}\text { L-malic acid : } \\
\text { sucrose : } \\
\text { water, } 2: 4: 2\end{array}$ & $\begin{array}{c}80^{\circ} \mathrm{C}, \\
18 \mathrm{~h}\end{array}$ & OPEFB & $\begin{array}{c}9.90 \% \\
\text { volatile mass } \\
\text { loss of lignin }\end{array}$ & \multirow{2}{*}{$\begin{array}{l}\text { Valorization } \\
\text { into useful } \\
\text { fuels and } \\
\text { chemicals }\end{array}$} & \multirow[t]{2}{*}{$\begin{array}{c}\text { Yiin et al. } \\
(2018 c)\end{array}$} \\
\hline $\begin{array}{c}\text { L-malic acid: } \\
\text { sucrose : } \\
\text { water, } 2: 4: 2\end{array}$ & $\begin{array}{c}80^{\circ} \mathrm{C}, \\
\text { overnight } \\
\text { magnetic } \\
\text { stirring }\end{array}$ & OPEFB & $\begin{array}{l}50.1 \% \text { lignin } \\
\text { removal }\end{array}$ & & \\
\hline
\end{tabular}




\begin{tabular}{|c|c|c|c|c|c|c|}
\hline \multirow[t]{3}{*}{$\begin{array}{c}\text { Organosolvent } \\
\text { pretreatment }\end{array}$} & $\begin{array}{c}65 \text { vol\% } \\
\begin{array}{c}\text { aqueous } \\
\text { ethanol }\end{array} \\
50 \text { vol\% } \\
\text { aqueous } \\
\text { ethanol, } 3 \text { vol\% } \\
\text { NaOH as } \\
\text { catalyst }\end{array}$ & $\begin{array}{l}160^{\circ} \mathrm{C} \\
65 \mathrm{~min}\end{array}$ & OPEFB & \begin{tabular}{|c|} 
Lignin \\
degradation of \\
$27.7 \%$ \\
\end{tabular} & $\begin{array}{c}\text { Feedstock } \\
\text { for } \\
\text { bioethanol }\end{array}$ & $\begin{array}{c}\text { Mardawat } \\
\text { et al. } \\
(2018)\end{array}$ \\
\hline & $\begin{array}{c}50 \text { vol\% aqueous } \\
\text { ethanol, } 2 \text { vol\% } \\
\mathrm{H}_{2} \mathrm{SO}_{4} \text { as the } \\
\text { catalyst }\end{array}$ & \multirow[b]{2}{*}{$\begin{array}{l}80^{\circ} \mathrm{C}, \\
30 \mathrm{~min}, \\
250 \mathrm{rpm}\end{array}$} & \multirow[b]{2}{*}{$\begin{array}{c}\text { Naturally } \\
\text { degraded } \\
\text { OPEFB }\end{array}$} & $\begin{array}{l}\text { Delignification } \\
\text { of } 53.2 \%\end{array}$ & \multirow[b]{2}{*}{$\begin{array}{c}\text { Feedstock for } \\
\text { biofuel } \\
\text { production }\end{array}$} & \multirow[b]{2}{*}{$\begin{array}{c}\text { Chin et al } \\
\text { (2019) }\end{array}$} \\
\hline & $\begin{array}{c}50 \text { vol\% aqueous } \\
\text { ethanol, } 2 \text { vol\% } \\
\mathrm{H}_{2} \mathrm{SO}_{4} \text { as the } \\
\text { catalyst }\end{array}$ & & & $\begin{array}{c}\text { Delignification } \\
\text { of } 41.8 \%\end{array}$ & & \\
\hline
\end{tabular}

\section{PHYSICAL PRETREATMENT}

The purpose of physical pretreatment is to decrease the particle size, thereby decreasing the crystalline structure and degree of polymerization and increasing the surface area, aiding the enzymatic hydrolysis in later steps (Nabilah-Jansar et al. 2018; Rizal et al. 2018a). Thus, physical pretreatments increase the accessible area of lignocellulosic biomass (Tian et al. 2018). Milling, microwave treatment, extrusion, and ultrasonication are physical (mechanical) pretreatments (Ahmad et al.2018a). After physical pretreatment, subsequent processes are more productive and easier to perform. Physical pretreatments are eco-friendly and rarely produce any toxic materials. However, drawbacks include high energy use for the operation of machinery (thus, being expensive) and an inability to be used on a large scale (Cardona et al. 2018). Table 3 lists various physical pretreatment methods used on oil palm biomass, their reaction conditions, and outcomes, while Fig. 4. depicts major physical pretreatment methods employed on oil palm biomass and their strengths.

\section{Milling}

Milling can dramatically reduce particle size to $0.2 \mathrm{~mm}$ (Moreno et al. 2019) and reduce the crystallinity of biomass (Baruah et al. 2018). It also leads to improved enzymatic hydrolysis and enhances the degree of polymerization. Milling does not give rise to any toxic or inhibitory compounds and does not require any harmful chemicals, making it a green approach (Moreno et al. 2019). Milling pretreatment techniques include ball milling, two-roll milling, colloid milling, rod milling, vibratory milling, hammer milling, and wet disk milling. Ball milling can loosen the cellulose structure, thereby retaining the microfiber structure in the hydrogen bond fracture (Tian et al. 2018). Shortcomings of milling pretreatment are high energy consumption during the process and the capital cost of mechanical equipment (Kapoor et al. 2018). 
Yusof et al. (2018) evaluated the environmental impact of bioethanol production from wet disc milling pretreated OPF. The study discovered that the most substantial environmental impact arises from the recovery procedure of sugar, contributing to more than $90 \%$ of the overall impact. This pronounced environmental impact is due to the requirement of enormous power by wet disc milling pretreatment. Since wet disc milling is a physical pretreatment method, the resultant biomass particle size would be quite small along with enhanced defibrillation, reflecting to an increased biomass surface area. Pronounced surface area through milling pretreatment enhances the accessibility of enzymes to lignocellulosic biomass, which promotes enzymatic digestibility to attain a high yield.

Zahari and co-workers (2014) compared wet disc milling and hammer milling as pretreatment methods on OPF to produce fermentable sugars. Fermentable sugar yield profiles from saccharified wet disc milled-OPF and hammer milled-OPF affirmed that wet disc milling contributes to an enhanced sugar release. Wet disc milled-OPF released the maximum glucose content with a concentration of $0.469 \mathrm{~g}$ per gram of OPF as opposed to $0.273 \mathrm{~g}$ of glucose per gram of OPF released through hammer milling. They manifested that the distinct disparity in sugar recovery can be attributed to the mode of action of the two milling pretreatments. Hammer milling engages the downsizing of lignocellulosic fiber length through cutting, whereas wet disc milling affects the reduction of fiber length utilizing two milling stones, which not only shortens the fiber particle size, but also applies shear force onto biomass fiber. Additionally, water employed in wet disc milling aids in reducing the distance between two milling stones to the barest minimum. Thus, wet disc milling produces refined microfibrils, which assists in easing the saccharification process. Saccharification of wet disc milled-OPF fibers using cellulase $(20 \mathrm{FPU} / \mathrm{g}$ loading, $48 \mathrm{~h}$, $0.05 \mathrm{M}$ acetate buffer) demonstrated that $95 \%$ of holocellulose composition was bioconverted into fermentable sugars compared to $60 \%$ of bioconversion with hammer milledOPF. They proposed that reducing sugars derived from efficient utilization of OPF through wet disc milling pretreatment could be employed in the sustainable production of poly(3hydroxybutyrate) bioplastic and bioethanol. Efficient utilization of oil palm biomass residues assists in minimizing the wastes generated at plantations, which benefit industries from accomplishing zero emission targets.

Although reduction of particle size through milling pretreatment could promote digestibility of oil palm biomass, the energy demand related to particle size reduction is quite significant, which exceeds the cost of particle size reduction.

\section{Extrusion}

The basis of extrusion is decreasing the particle size by rotating one or two screws in a tight barrel at high temperature (Peinemann and Pleissner 2020). The raw materials are passed through the barrel under high temperatures $\left(>300{ }^{\circ} \mathrm{C}\right)$, where the action of the screws breaks down the lignocellulose biomass, and the high temperature causes chemical changes in the biomass. The design of the screws, the rotational speed, and the temperature within the barrel are the main parameters controlling the extrusion pre-treatment (Gatt et al. 2018).

There are two types of extrusion machines: single-screw extruders and twin-screw extruders (Ariffin et al. 2018). Extrusion increases accessibility of cellulose and does not produce inhibitors such as furfural and HMF, so washing and detoxification are not needed. Extrusion can easily be scaled up to commercial-scale operations, as it can operate continuously and is eco-friendly, and modifications can be made according to needs 
(Tayyab et al. 2018). The main drawback of this method is the very high energy consumption of the process (Peinemann and Pleissner 2020).

Gatt et al. (2018) pointed out that extrusion with an enzyme cocktail, known as bioextrusion, is one of the reactive extrusion configurations and a novel pretreatment technique. Bioextrusion introduces enzymes to the medium as biocatalysts during the extrusion pretreatment. However, bioextrusion pretreatment suffers from two major drawbacks, which are insufficient residence time (typically 1 to $5 \mathrm{~min}$ ) and difficulties in temperature regulation during the pretreatment. Their review study highlighted that bioextrusion of lignocellulosic biomass results in a higher sugar production yield. Since bioextrusion is still an evolving pretreatment technique, bioextrusion of lignocellulosic biomass has yet to gain increased attention among researchers. Vandenbossche et al. (2014) investigated a novel OPEFB deconstruction process with an alkaline pretreatment and bioextrusion in a twin-screw extruder. It was shown that deconstruction process of OPEFB did not produce any toxic byproducts retarding the saccharification. They pointed out the benefits of the novel process can be ascribed to the utilization of minimal energy through the operation at a low temperature, requirement of low water content, and being able to rapidly perform the deconstruction process. Bioextrusion was carried out through the introduction of an enzyme cocktail (cellulase and hemicellulase) into the extruder, which then undergoes successive compression (through mechanical pressure) and relaxation to enable the accessibility of enzyme cocktail into OPEFB, ensuring an ultimate contact. The study emphasized that the addition of saccharification enzymes into the extruder upon alkaline pretreatment assisted in the disruption of OPEFB fibers. The authors observed a significant increment in cellulose content compared to lignin and hemicellulose composition, which corresponds to the production of fine OPEFB fibers upon bioextrusion. Enzymatic hydrolysis yield of only $26 \%$ was attained due to the presence of a high amount of lignin in OPEFB. It can be concluded that combining alkaline pretreatment with bioextrusion has potential applicability in an OPEFB-based biorefinery for ethanol production, which could be further enhanced by optimizing pretreatment conditions.

\section{Microwave Pretreatment}

Microwave pretreatment is an emerging technique that employs a heating method beyond traditional heating (Tian et al. 2018). In this method, the biomass is exposed to electromagnetic radiation, which induces collisions of polar molecules within the biomass, producing heat by dielectric heating (López-Linares et al. 2019). The generated heat can disrupt complex lignocellulosic structures (Hassan et al. 2018). Microwave pretreatment is easy to operate and requires minimal space. Moreover, it consumes less energy and can yield high temperatures within a short time (Bichot et al. 2020). It does not produce any inhibitory products and is non-toxic, so it is eco-friendly (Bichot et al. 2019). To attain efficient hydrolysis, microwave heating can be coupled with acids and alkaline compounds (López-Linares et al. 2019). One such organic dicarboxylic acid that can be combined with microwave heating is maleic acid, which generates less inhibitory products compared to sulfuric acid, as it selectively hydrolyzes $\beta-(1,4)$ bonds (Fatriasari et al. 2018).

Fatriasari et al. (2018) studied the effects of microwave pretreatment conditions (temperature, irradiation time, and maleic acid concentration) on the enzymatic hydrolysis performance of OPEFB in producing bioethanol. They found that microwave pretreatment temperature had the greatest effect on bioethanol production, as opposed to irradiation time and maleic acid concentration. Microwave pretreatment was conducted within a temperature range of 160 to $200{ }^{\circ} \mathrm{C}$ with $2.5 \mathrm{~min}$ of irradiation time. The effect of 
pretreatment temperature at 2.5 min irradiation time revealed that as the irradiation temperature increased, pulp recovery reduced, owing to the loss of chemical components consequent to pretreatment. OPEFB pretreated at $190{ }^{\circ} \mathrm{C}$ recorded the highest cellulose composition $(57.5 \%)$. Since microwave irradiation causes oil palm biomass fibers to become disrupted and removes lignin and hemicellulose content, severe pretreatment above $190{ }^{\circ} \mathrm{C}$ according to this study attained the lowest cellulose content (44.0\%) due to the degradation of cellulose. Up to $190{ }^{\circ} \mathrm{C}$ heating temperature, the reducing sugar yield increased, but it declined at $200{ }^{\circ} \mathrm{C}$, corroborating to the trend observed in alpha cellulose content. An optimal reducing sugar yield of $47.2 \%$ was achieved upon pretreatment at 190 ${ }^{\circ} \mathrm{C}$. The reduction of reducing sugar yield above $190{ }^{\circ} \mathrm{C}$ could be attributed to their degradation into inhibitory compounds including 5-HMF and furfural. The effect of irradiation time (at $190^{\circ} \mathrm{C}$ ) on cellulose content showed a directly proportional correlation apart from $10 \mathrm{~min}$ irradiation. Longer irradiation time could effectively remove more amorphous phase to provide a higher cellulose content. On the other hand, pulp recovery declined with increasing irradiation time. Prolonged irradiation time resulted in a poor reducing sugar yield although hemicellulose and lignin removal was high. Thus, they suggested that the removal of lignin and hemicellulose contributes only to enhance the digestibility of OPEFB. However, microwave pretreatment is not feasible at the commercial scale, as it requires much expert knowledge and high initial costs for the machines if expanded to a large scale.

\section{Ultrasonication}

Currently, one of the most novel approaches of oil palm biomass pretreatment and delignification is based on energy irradiation methods including ultrasound (Ofori-Boateng and Lee 2014; Budiman and Wu 2016; Yasim-Anuar et al. 2018; Ong et al. 2019; Isa et al. 2020). Ultrasonication employs a combination of mechanical vibration and sonochemical effects on lignocellulosic biomass (Debiagi et al. 2020). In this process, ultrasonic radiation in the frequency range of 10 to $20 \mathrm{MHz}$ is passed through the biomass, causing chemical and physical effects and producing cavities in the biomass. The disruption of the network structure causes the separation of cellulose, hemicellulose, and lignin (Baruah et al. 2018). Several factors govern the effectiveness of the ultrasonic treatment, such as the frequency of the ultrasonic radiation, the duration for which the radiation is passed through the biomass, and whether the radiation is supplied continuously or as a pulse (Ahmad et al. 2018c; Baruah et al. 2018).

The bubbles generated in the cavitation process also help to increase the surface area, thereby increasing the amount of cellulose available for cellulose enzymes. This is suitable for biomass with a small particle size. Ultrasonication can be coupled with other pretreatment methods to increase efficiency and reduce costs. However, if the ultrasonic radiation is provided for an extended period, it causes adverse effects (Kapoor et al. 2018).

Since palm oil mill effluent (POME) contains a high amount of insoluble organic matter (4 to $5 \%$ total solids) and a high concentration chemical oxygen demand (COD), the application of POME can serve as a raw material, being a cost effective approach at the same time to produce biogas has attracted increased interest among researchers. At present, there is limited research converging on improving the production of biogas from POME through ultrasonication pretreatment at different mesophilic temperatures. Even though biogas production could be achieved through anaerobic treatment of POME, the difficulty of solubilizing organic compounds in POME retards the process. Thus, several research 
studies have been carried out in improving the solubility of organic solids in POME with the application of ultrasound pretreatment.

Wong et al. (2018a) employed anaerobic digestion upon ultrasonication pretreatment of POME owing to its cost effectiveness and capability to produce biogas. They pointed out that ultrasonication is a viable pretreatment to disintegrate insoluble organic matter in POME, where they found that low frequency ultrasound significantly improved the solubilization of POME, signifying the plausibility to employ ultrasonication with anaerobic digestion in pretreating POME to improve biogas production. It was highlighted that solubilization of organic content in POME directly affects the anaerobic digestion rate as well as the yield of biomethane. According to their study, the concentration of soluble COD in POME can be used as a quantitative measure to evaluate the effectiveness of a pretreatment application. Ultrasonication density of $0.88 \mathrm{~W} / \mathrm{mL}$ and $16.20 \mathrm{~min}$ of ultrasonication time resulted in $16.1 \%$ solubilization of organic matter and attained a soluble COD concentration of $31,700 \mathrm{mg} / \mathrm{L}$.

Isa and co-workers (2020) studied the use of ultrasonication pretreatment in improving anaerobic digestion of palm oil mill effluent (POME) and biogas production. Conversion of POME waste into biogas was carried out by employing ultrasound at temperatures in the range of 25 to $45^{\circ} \mathrm{C}$. The study investigated the effect of ultrasonication on the POME organic matter disintegration and the removal of COD in order to increase the biogas and methane yield. Biological treatment was conducted using anaerobic sequencing batch reactors at various temperatures in the mesophilic range with ultrasonic radiation of $20 \mathrm{kHz}$, supply power of $500 \mathrm{~W}, 16.2 \mathrm{~min}$ ultrasonication time, and $0.88 \mathrm{~W} / \mathrm{mL}$ of ultrasonication density. Their study revealed that ultrasonication pretreatment is a potent pretreatment in enhancing biogas production and obtain a higher disintegration of POME (breaks the organic matter into simple organics) in the temperature range between 30 and $35{ }^{\circ} \mathrm{C}$. Introducing ultrasonicated POME into the anaerobic sequencing batch reactor operated at $30{ }^{\circ} \mathrm{C}$ experienced the highest removal efficiency of COD at $95 \%$. Houtmeyers et al. (2014) elaborated that during the application of ultrasound pretreatment on POME, cavitation microbubbles are formed, which become bigger in size until they burst upon attaining a critical size. During the bursting of microbubbles, the energy released causes water to decompose, forming reactive radicals (Zhang et al. 2018). These reactive radicals disintegrate organic matter. Wong et al. (2018b) emphasized that the mechanical, thermal and sonochemical effects generated through ultrasound irradiation expedite and ease the anerobic biodegradation owing to the effective solubilization of insoluble organics in POME. Thus, ultrasonication endured POME results in high concentration of simple organics. Isa et al. (2020) observed that sonicated POME fed anaerobic sequencing batch reactor functioned at $30{ }^{\circ} \mathrm{C}$ achieved a $21.5 \%$ increment in methane yield along with the production of the maximum amount of biogas $(3465 \mathrm{~mL})$. Wong et al. (2018b) suggested that an increased anerobic digestion rate can be attributed to the reduction in particle size of organics in POME which in turn improves their surface area for an efficient microbial degradation. Thus, it can be concluded that ultrasound pretreatment converts insoluble organic matter in POME into simpler structures for easy digestion, which promotes the production of biogas. 
Budiman and $\mathrm{Wu}$ (2016) performed ultrasonic irradiation on POME in view of enhancing photofermentative biohydrogen production. The influence of ultrasound amplitude (30 to $90 \%$ ) and retention time of ultrasonication (5 to $60 \mathrm{~min}$ ) on biohydrogen production yield and COD removal were evaluated. They found that the optimum ultrasonication conditions to pretreat POME were $70 \%$ amplitude and 45 min of retention time. It was observed that under optimal conditions (at $30{ }^{\circ} \mathrm{C}$ ), cumulative COD removal of $36.9 \%$ and an $8.72 \mathrm{~mL} \mathrm{H} / \mathrm{mLmedium}$ biohydrogen production were attained. The data obtained confirmed that ultrasonication was effective in solubilizing complex organic content in POME. They noted that ultrasonicated POME significantly improved biohydrogen yield as opposed to untreated POME, where increasing ultrasonication amplitude resulted in a reduction of both lignin and cellulose content. Moreover, the study revealed that improvement of the biohydrogen yield was the highest for sonicated POME using high ultrasound energy inputs (775 and $997 \mathrm{~J} / \mathrm{mL}$ ), conforming to enhanced surface area of the substrate (i.e. improved bioavailability) upon ultrasonication. The authors emphasized that swift internal heating prompted the solubilization of complex organics into the liquid phase. Based on their study, it can be concluded that extreme ultrasonication pretreatment conditions do not enhance biohydrogen production.

\section{Milling}

- Ball milling

- Disc milling

- Two-roll milling

- Colloid milling

- Rod milling

- Vibratory milling

- Hammer milling

\section{Ultra-high pressure}

Effectively enhance the phenolic bioaccessibilities and bioactivities of phenolic-rich extracts

\section{Microwave}

Improves the disruption of the recalcitrant structures of oil palm biomass and accelerates the destruction of the crystal structures (enhanced cellulose digestibility)

\section{Ultrasonication}

Facilitates the hydrolysis of cellulose and hemicellulose to sugars and improves the fermentation of sugars to bioethanol

\section{Extrusion}

- Single-screw

- Twin-screw

- Co-rotating twin screw

- Variable hydro-module
Improves enzymatic hydrolysis and enhances degree of polymerization

Fig. 4. Major physical pretreatment methods employed on oil palm biomass and their strengths 
Table 3. Overview of Various Physical Pretreatment Methods Employed on Oil Palm Biomass and Their Potential Applications

\begin{tabular}{|c|c|c|c|c|c|c|}
\hline $\begin{array}{l}\text { Pretreatment } \\
\text { Method }\end{array}$ & $\begin{array}{l}\text { Major Agents } \\
\text { Used }\end{array}$ & Conditions & $\begin{array}{l}\text { Oil Palm } \\
\text { Biomass }\end{array}$ & $\begin{array}{l}\text { Concluding } \\
\text { Remarks }\end{array}$ & $\begin{array}{l}\text { Potential } \\
\text { Application }\end{array}$ & Reference \\
\hline Irradiation & Microwaves & $\begin{array}{c}2450 \mathrm{MHz} \\
450 \mathrm{~W}, 5 \\
\min \end{array}$ & $\begin{array}{l}\text { OPEFB } \\
\text { OPMF }\end{array}$ & $\begin{array}{l}29.1 \% \text { of } \\
\text { crystallinity of } \\
\text { a-cellulose of } \\
\text { OPEFB } \\
23.8 \% \text { of } \\
\text { crystallinity of } \\
\text { a-cellulose of } \\
\text { OPMF }\end{array}$ & - & $\begin{array}{c}\text { Kasim et al. } \\
\quad(2018)\end{array}$ \\
\hline Milling & Disc mill & $\begin{array}{l}20 \text { cycles, } \\
\text { wet } \\
\text { condition }\end{array}$ & OPF & $\begin{array}{c}95 \% \text { of } \\
\text { holocellulose } \\
\text { conversion } \\
\text { into sugars }\end{array}$ & $\begin{array}{l}\text { Production } \\
\text { of } \\
\text { bioethanol }\end{array}$ & $\begin{array}{l}\text { Zahari et al. } \\
\text { (2014) }\end{array}$ \\
\hline Bioextrusion & \begin{tabular}{|c|} 
Twin-screw \\
extruder, \\
cellulase, \\
hemicellulase
\end{tabular} & $\begin{array}{c}200 \text { rpm } \\
40^{\circ} \mathrm{C}, 1.5-3 \\
\min \end{array}$ & OPEFB & $\begin{array}{c}\text { Enzymatic } \\
\text { hydrolysis } \\
\text { yield of } 26 \%\end{array}$ & $\begin{array}{l}\text { Production } \\
\text { of } \\
\text { bioethanol }\end{array}$ & $\begin{array}{c}\text { Vandenbossche } \\
\text { et al. (2014) }\end{array}$ \\
\hline Milling & Ball mill & $60 \mathrm{rpm}, 48 \mathrm{~h}$ & OPEFB & $\begin{array}{c}38.5 \% \\
\text { increment of } \\
\text { sugar alcohol } \\
\text { yield }\end{array}$ & $\begin{array}{l}\text { Production } \\
\text { of sugar } \\
\text { alcohols }\end{array}$ & $\begin{array}{l}\text { Yamaguchi } \\
\text { et al. (2016) }\end{array}$ \\
\hline $\begin{array}{l}\text { Ultra-high } \\
\text { pressure }\end{array}$ & $\begin{array}{l}\text { Water as a } \\
\text { pressure- } \\
\text { transmitting } \\
\text { medium }\end{array}$ & $\begin{array}{c}25^{\circ} \mathrm{C}, \\
500 \mathrm{MPa}, \\
10 \mathrm{~min}\end{array}$ & OPMF & $\begin{array}{c}12 \text { phenolic } \\
\text { compounds } \\
\text { were } \\
\text { quantified }\end{array}$ & $\begin{array}{l}\text { Functional } \\
\text { food or the } \\
\text { nutraceutic } \\
\text { al industry }\end{array}$ & $\begin{array}{c}\text { Zhou et al. } \\
(2019)\end{array}$ \\
\hline Ultrasonication & $\begin{array}{c}\text { Probe type } \\
\text { ultrasonication } \\
\text { processor }\end{array}$ & $\begin{array}{c}20 \mathrm{kHz}, 16.2 \\
\mathrm{~min}, 0.88 \\
\mathrm{~W} / \mathrm{mL}\end{array}$ & POME & $\begin{array}{l}21.5 \% \text { higher } \\
\text { methane yield } \\
\text { compared to } \\
\text { raw POME }\end{array}$ & $\begin{array}{l}\text { Production } \\
\text { of biogas }\end{array}$ & $\begin{array}{l}\text { Isa et al. } \\
(2020)\end{array}$ \\
\hline
\end{tabular}

\section{PHYSICOCHEMICAL PRETREATMENT}

Physicochemical pretreatment combines chemical pretreatment with physical pretreatment for an improved pretreatment with decreased reaction time and increased efficiency of delignification. Physicochemical pretreatments include steam explosion, superheated steam (SHS) pretreatment, ammonia fiber expansion, liquid hot water treatment, carbon dioxide explosion, and wet oxidation (Ahmad et al. 2018a). Table 4 describes previous literature on different physicochemical pretreatment methods for oil palm biomass, including the reaction conditions that were employed and the outcome of each technique. 


\section{Steam Explosion}

Steam explosion pretreatment is an efficient method for the disruption of cellulose crystallinity and removal of hemicellulose (Ouyang et al. 2018; Siramon et al. 2018). In this process, high-pressure saturated steam is allowed to penetrate the biomass (Choopakar et al. 2018). The steam has a temperature between $150{ }^{\circ} \mathrm{C}$ and $260{ }^{\circ} \mathrm{C}$ and is trapped at a pressure between $0.69 \mathrm{MPa}$ and $4.83 \mathrm{MPa}$ for approximately $30 \mathrm{~s}$ to $20 \mathrm{~min}$. The pressure is then suddenly released, making the water molecules leak out and causing an explosion. This explosion is capable of breaking the glycosidic bonds between cellulose and hemicellulose, as well as bonds between hemicellulose and lignin (Pangsang et al. 2019). The hemicellulose is converted to fermentable sugars and produces organic acids, which are capable of further hydrolyzing hemicellulose. Therefore, this process is considered an autohydrolysis process (Noorshamsiana et al. 2017). The chemical effect of this process is caused by the acetyl groups of hemicellulose, which cause the autohydrolysis that causes chemical changes in the biomass.

Furthermore, water acts as an acid at high temperatures, which also aids in the chemical changes. The breakdown of hemicellulose exposes more cellulose for cellulase and leads to an increase in enzymatic activity (Kapoor et al. 2018). Reaction time, the moisture content of the biomass (Ahmad et al. 2018c), steam temperature, the type of biomass used, and the particle size of the biomass are some factors that govern this process. The process is cost-effective and is easily performed on a pilot scale (Kapoor et al. 2018). The energy input is low, and, as the chemicals are auto-generated, there is no need for recycling. Moreover, this has minimum environmental impact and is suitable for further microbial treatment, as acidic conditions are being used (Tayyab et al. 2018). However, the high temperatures can lead to partial degradation of hemicellulose, and some amount of cellulose is also hydrolyzed. Also, fermentation inhibitors may be produced (Surya et al. 2018), which can hinder further steps. Therefore, washing is needed before the subsequent steps, which also removes some amount of soluble sugars (Boon et al. 2019).

Medina et al. (2016) demonstrated a biorefinery approach with steam explosion pretreatment of OPEFB under autocatalytic conditions. The optimal efficacy was obtained pretreating OPEFB at $195{ }^{\circ} \mathrm{C}$ for $6 \mathrm{~min}$, which enhanced the cellulose content by $24 \%$ together with a hemicellulose reduction of $68 \%$. Screening of pretreatment conditions disclosed that increased pretreatment severity negatively affected the OPEFB solid recovery. However, pretreated OPEFB at $212{ }^{\circ} \mathrm{C}$ for 8 min attained a $12 \%$ increment in cellulose composition. Conversely, raising the pretreatment temperature resulted in an enhanced degradation of hemicellulose. Obtaining cellulose rich and hemicellulose deficient oil palm biomass fibers after an effective pretreatment is vital for successive biotransformation in producing value-added products including bioethanol, organic acids and biobutanol. FTIR analysis revealed that with increased pretreatment temperature, the intensity of IR peaks at 1461 and $1415 \mathrm{~cm}^{-1}$ increased, which is related to the increase in cellulose content. Moreover, with increased pretreatment severity, the intensity of the band positioned at $1098 \mathrm{~cm}^{-1}$ (corresponds to $\beta$-glycosidic bonds) decreased, which indicates the loss of $\beta$-linked hemicelluloses. Compositional analysis of pretreated OPEFB demonstrated that the cellulose content after steam explosion pretreatment above $195{ }^{\circ} \mathrm{C}$ declined gradually, owing to the formation of fermentative inhibitory compounds including HMF, furfural, and acetic acid. The efficacy of pretreatment with respect to promotion of enzymatic hydrolysis of OPEFB showed that severe pretreatment conditions enhanced the hydrolysis. Pretreatment performed at $195{ }^{\circ} \mathrm{C}$ for $6 \mathrm{~min}$ yielded the highest enzymatic hydrolysis of $33.4 \%$ along with a glucose concentration of $4.18 \mathrm{~g} / \mathrm{L}$. Enzymatic 
digestibility and glucose yield obtained at $195^{\circ} \mathrm{C}$ showed a more than two-fold increase in comparison to pretreatment at $175{ }^{\circ} \mathrm{C}$ and $185{ }^{\circ} \mathrm{C}$. They found out that hydrolysates contained fermentable sugars (glucose, arabinose, and xylose) as well as significant amounts of acetic acid. Their study suggested that steam explosion pretreatment could be utilized in producing liquid hydrolysates rich fermentable sugars from OPEFB upon a successive separation step to remove inhibitory compounds, which promotes the sustainability of OPEFB-based biorefineries.

\section{SHS Pretreatment}

Superheated steam pretreatment, a type of steam pretreatment, is effective in disrupting the structural arrangement of lignocellulosic components. Superheated steam is dry steam that is produced by adding heat to wet steam. The additional heat helps the saturated steam to reach the boiling point of the liquid at a lower pressure compared to steam explosion pretreatment (Rizal et al. 2018b). Similar to steam explosion, this method also employs high-temperature steam, but it does not use high pressure. This method can modify the structure of the fibers, allowing them to be more exposed to enzyme reactions in the downstream steps. Superheated steam pretreatment is a novel, eco-friendly method and can be paired to increase efficiency (Noorshamsiana et al. 2017). A high amount of hemicellulose from the lignocellulosic fiber can be removed efficiently by SHS pretreatment, as the hemicellulose degrades at a temperature just greater than $180{ }^{\circ} \mathrm{C}$, making it less thermally stable than cellulose and lignin (Rizal et al. 2018a). Benefits of SHS pretreatment include its high drying rate, low energy consumption, high productivity, and environmentally benign nature, as it is performed at atmospheric pressure (Norrahim et al. 2018).

Several studies have been conducted on the use of SHS with laccase pretreatment. Heating OPEFB with SHS at $180{ }^{\circ} \mathrm{C}$ for $60 \mathrm{~min}$, followed by enzyme degradation through laccase produced by Trametes versicolor (100 U/g substrate), was able to remove $38.7 \%$ of lignin (Rizal et al. 2018b). The same reaction performed with the SHS at $190{ }^{\circ} \mathrm{C}$ for 60 min, followed by degradation through laccase produced by $T$. versicolor $(400 \mathrm{U} / \mathrm{g}$ substrate), was able to remove a slightly greater amount of lignin (39.6\%), implying that the changes in temperature and substrate concentration had little effect on the delignification process. They found that increased temperature gave rise to the degradation of acetyl groups in hemicellulose, forming acetic acid, whereas hexose and pentose sugars degraded into furfural and HMF. A greater decrease of hemicellulose upon pretreating with superheated steam resulted in an improved lignin and cellulose content, which made the structural arrangement weaker. This observation was backed up by attaining an increased glucose content upon the saccharification of the SHS pretreated OPEFB sample. Sun et al. (2016) noted that the efficiency of saccharification largely depends on the effectiveness of the applied pretreatment.

Zakaria et al. (2015) employed superheated steam pretreatment on OPMF with a lab-scale superheated steam machine. SHS pretreatment was conducted at a temperature range of 190 to $210{ }^{\circ} \mathrm{C}$ for $60 \mathrm{~min}$ and found that hemicellulose content was affected with the application of SHS pretreatment, where hemicellulose content declined with increased pretreatment temperature. Pretreatment with SHS at $210{ }^{\circ} \mathrm{C}$ for 60 min recorded a hemicellulose degradation of $42.0 \%$. They emphasized that defibrillation of OPMF is one of the key factors to achieve high conversion of bio-sugars. Nonetheless, cellulose content declined when the pretreatment temperature was greater than $200{ }^{\circ} \mathrm{C}$ similar to the trend attained by Nordin and co-workers. (2013). According to the chemical compositions of 
SHS-pretreated OPMF reported by Zakaria et al. (2015), the maximum cellulose content (34.7\%) was attained at $190{ }^{\circ} \mathrm{C}$ for $60 \mathrm{~min}$, whereas the cellulose content recorded a reduction at higher temperatures above $190{ }^{\circ} \mathrm{C}$. Moreover, at smaller size of OPMF samples $(<2 \mathrm{~mm})$, a higher hemicellulose dissolution was recorded. In terms of lignin content, higher SHS pretreatment temperatures favored an increase of the lignin content of OPMF. Increased lignin composition with increasing SHS pretreatment temperature can be ascribed to the weakening of hydroxyl groups in hemicellulose (Nordin et al. 2013). Efficiency of SHS pretreatment on OPMF was evaluated by the efficiency of enzymatic saccharification, which in turn increases the degree of conversion of cellulose to hydrolyzed sugars. It was observed that increasing the pretreatment temperature resulted in an increased xylose yield, where the maximum xylose yield of $10.7 \%$ was obtained at $210{ }^{\circ} \mathrm{C}, 60 \mathrm{~min}$. They highlighted that the extent of defibrillation and reduction of particle size of OPMF were crucial in improving the conversion of hydrolysable sugars. Nordin et al. (2013) reported a similar hemicellulose degradation value of $49.2 \%$ to that of Zakaria et al. (2015) upon SHS pretreatment applied on OPMF at $210{ }^{\circ} \mathrm{C}$ for $60 \mathrm{~min}$. They highlighted that SHS pretreatment could lay a platform as a green and a sustainable approach to modify the surface of natural fibers.

Nik Mahmud et al. (2013) evaluated the performance of enzymatic saccharification of OPMF for bio-sugar production with SHS pretreatment within a temperature range of 140 to $210{ }^{\circ} \mathrm{C}$ with a retention time varying from 20 to $90 \mathrm{~min}$. It was observed that SHS pretreatment at $180{ }^{\circ} \mathrm{C}$ with a retention time of 60 min offered the optimum condition for enzymatic saccharification of OPMF. Moreover, they discovered that SHS applied at a temperature of $210^{\circ} \mathrm{C}$ and above degraded hemicellulose and cellulose content in OPMF, suggesting that pretreatment of OPMF with SHS at $210{ }^{\circ} \mathrm{C}$ and above do not favor the production of bio-sugars. Scanning electron microscopy (SEM) images and DTG analysis upon SHS pretreatment on OPMF demonstrated the effective removal of silica bodies and hemicellulose, respectively. It was observed that SHS pretreatment of OPMF at $180{ }^{\circ} \mathrm{C}$ for 60 min enhanced enzymatic digestibility by $58.3 \%$. Their study revealed that SHS pretreatment was effective in improving the digestibility and deconstruction of the highly recalcitrant structure of OPMF, consequently enhancing enzymatic saccharification for bio-sugar production.

\section{Liquid Hot Water Pretreatment}

Utilization of liquid hot water is another pretreatment method mainly intended to remove hemicelluloses from lignocellulosic biomass (Risanto et al. 2018), as shown in Fig. 5. In this method, lignocellulosic biomass is subjected to liquid hot water in a temperature range of 150 to $260^{\circ} \mathrm{C}$ and at a pressure of up to $3 \mathrm{MPa}$ (Pangsang et al. 2018). The pressure is applied to prevent the evaporation of the water and is not rapidly released, so explosion is not observed. The cellulose becomes more vulnerable to enzymatic digestion, as it readily hydrolyzes hemicellulose and removes lignin (Cardona et al. 2018). At such reaction conditions, $\mathrm{H}_{3} \mathrm{O}^{+}$acts as an autocatalyst to break the glycosidic linkages and enhance enzyme accessibility for efficient hydrolysis (Nadia et al. 2018a).

Inhibitor formation can be controlled by maintaining a pH between 4 and 7 (Risanto et al. 2018). Liquid hot water pretreatment requires no chemicals as catalysts; it is environmentally friendly, non-toxic, and cost-effective (Ali et al. 2020). Because it employs water rather than a base or acid, no chemical recovery step is needed (Nadia et al. 2018a). However, it requires large amounts of water and energy if it is expanded to industrial scale (Ali et al. 2020). Nadia et al. (2018a) employed fast hot compressed water 
pretreatment (15 min holding time) on OPF at various pretreatment temperatures in a batch autoclave. Upon enzymatic hydrolysis, the maximum fermentable sugar content of $50.5 \%$ (w/v) was obtained with pretreatment of the OPF for $15 \mathrm{~min}$ at $190{ }^{\circ} \mathrm{C}$.

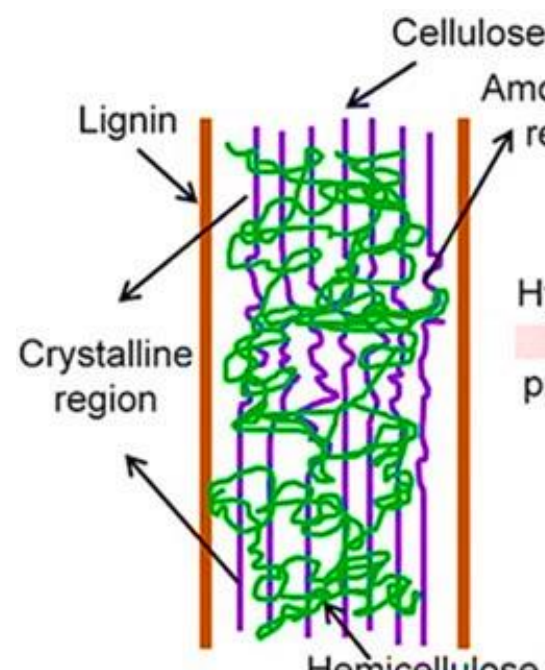

(a)

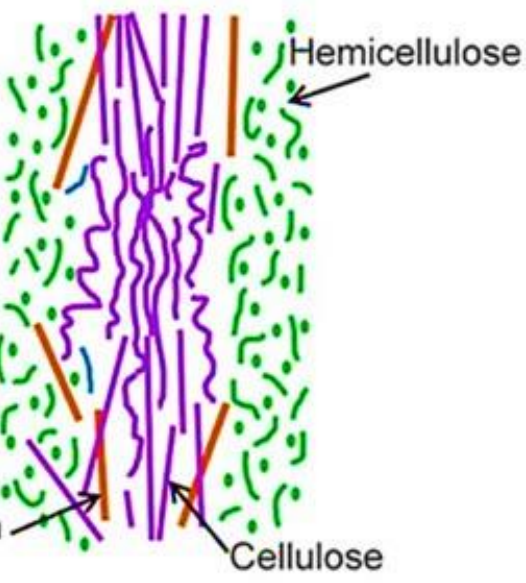

(b)

Fig. 5. Graphical depiction of (a) pristine biomass and (b) the importance of hydrothermal pretreatment in biomass advancement (adapted from He et al. (2018))

Since OPT is rich in starch, solubilization of a large portion of starch can be achieved under less severe conditions, enabling water to be used as the only reaction medium in the absence of any acid or base catalysts. Therefore, hydrothermal pretreatment is appropriate to pretreat starch-rich oil palm biomass residues such as OPT. Eom and coworkers (2015) investigated a simple and effective approach to produce ethanol through hydrothermal pretreatment with subsequent enzymatic hydrolysis and fermentation, without the use of any acids, bases, or detoxification. The cited authors studied the effect of pretreatment temperatures ( 160 to $200{ }^{\circ} \mathrm{C}$ at intervals of $10{ }^{\circ} \mathrm{C}$ for $30 \mathrm{~min}$ ) suitable to maximize the glucose yield from OPT through enzymatic hydrolysis. They found that when hydrothermal pretreatment was employed on OPT at $180{ }^{\circ} \mathrm{C}$ for $30 \mathrm{~min}$, an optimum yield of glucose can be obtained with the generation of a very low amount of degradation products such as furfural and HMF. An optimum glucose yield of $81.3 \%$, which resulted in ethanol yield of $81.4 \%$ was attained with hydrothermal pretreatment conditions of 180 ${ }^{\circ} \mathrm{C}$ for $30 \mathrm{~min}$. Moreover, a hemicellulosic sugar yield (including xylose, galactose, mannose) of $75.3 \%$ was obtained. As the pretreatment temperature exceeded $180{ }^{\circ} \mathrm{C}$, glucose yield was significantly reduced to 59.4\%. Moreover, as the hydrothermal temperature was increased above $180{ }^{\circ} \mathrm{C}$, the generation of both furfural and $\mathrm{HMF}$ increased exponentially. It can be concluded that increasing pretreatment severity solubilizes some of the starch to form HMF and furfural, which reduces the glucose yield produced from the OPT. Thus, it is vital to pretreat OPT under a less severe condition to curtail starch degradation in view of maximizing the ethanol yield. For subsequent enzymatic hydrolysis (Cellic ${ }^{\circledR}$ CTec2, Cellic ${ }^{\circledR}$ HTec2, and Novozyme-188), a $0.05 \mathrm{M}$ sodium citrate buffer ( $\mathrm{pH}$ 5) was used to regulate the $\mathrm{pH}$ and $330 \mathrm{mg} \mathrm{L}^{-1}$ sodium azide was employed to avoid microbial contamination. Enzymatic hydrolysis was carried out for 72 $\mathrm{h}$ at $50{ }^{\circ} \mathrm{C}$ with a stirring speed of $200 \mathrm{rpm}$. The ethanol fermentation process was carried 
out using $5 \mathrm{~g} \mathrm{~L}^{-1}$ Saccharomyces cerevisiae yeast extract at $30{ }^{\circ} \mathrm{C}$ with a stirring speed of $200 \mathrm{rpm}$ for $24 \mathrm{~h}$.

A study carried out by Ramachandran et al. (2020) demonstrated that the combination of genetically modified microbes with hydrothermal pretreatment technique can contribute towards the production of value-added products such as aromatic chemicals. employed hydrothermal pretreatment at different temperatures $\left(100{ }^{\circ} \mathrm{C}\right.$ to $200{ }^{\circ} \mathrm{C}$ with increments of $20^{\circ} \mathrm{C}$ ) and microbial treatment to valorize OPEFB into value-added aromatic chemicals including protocatechuic acid and vanillin. For biological treatment (microbial processing), $\Delta$ pcaHG Rhodococcus jostii RHA1 mutant was utilized. In their study, Rhodococcus jostii RHA1 Gram-positive bacterium was employed, as bacteria are easier to be genetically manipulated compared to fungi as a strategy to enhance the degradation of lignin. GC-MS analysis revealed that pretreatment temperature affected the types of single aromatic chemicals (including phenol, benzoic acid, 2-methoxy-4-vinylphenol, 4hydroxybenzoic acid, 3,4,5-trimethoxyphenol, 4-hydroxy-3,5-dimethoxybenzaldehyde, butylated hydroxytoluene and 4-TMS-benzoic acid) produced from the hydrothermal process. It was clear that the total area of single aromatic chemicals generated improved as the temperature was elevated from $100{ }^{\circ} \mathrm{C}$ to $200{ }^{\circ} \mathrm{C}$. Pretreatment at $200{ }^{\circ} \mathrm{C}$ attained the highest total area of single aromatic chemicals, which was much higher than that at 100 ${ }^{\circ} \mathrm{C}$. Since the degree of lignin depolymerization is highly reliant on the applied temperature, increased temperature provides more energy to depolymerize a polymer of lignin to oligomers of lignin, which then produces a monomer of lignin. Moreover, the rate of depolymerization also depends on the amount of $\mathrm{H}^{+}$and $\mathrm{OH}^{-}$present, which acts as a catalyst. Elevated temperature increases the ionic product of water, which produces a high amount of $\mathrm{H}^{+}$and $\mathrm{OH}^{-}$ions. Viscosity of water also is reduced with increased temperature, resulting in a rapid mass transfer. It was deduced that the type of single aromatic chemicals formed employing hydrothermal pretreatment depends on the pretreatment temperature and the aromatic chemicals produced could inhibit or act as precursors in producing protocatechuic acid.

Liquid hot water pretreatment removes hemicellulose from oil palm biomass, thereby improving the digestibility of cellulose. Nevertheless, the formation of inhibitory compounds during the pretreatment is a major flaw of high temperature strategies including liquid hot water pretreatment.

\section{Wet Oxidation}

In this method, water and air at a temperature greater than $120{ }^{\circ} \mathrm{C}$ (Ali et al. 2020) and a pressure between 0.5 and $2 \mathrm{MPa}$ for approximately $15 \mathrm{~min}$ are used as a catalyst. At elevated temperatures, water behaves as an acid and hydrolyzes hemicellulose. The organic acid formed carries on with delignification of the biomass. The temperature of the medium, the reaction time, and the pressure are the three crucial factors that affect the efficiency of wet oxidation (Tayyab et al. 2018). Coupling of this method with other chemical pretreatments can enhance productivity. This method is inexpensive and produces fewer toxins. However, one should take extra precautions if expanding to industrial scale, as oxygen is highly flammable (Kapoor et al. 2018).

Lee et al. (2020) performed wet oxidation pretreatment in view of mitigating the recalcitrance of OPEFB to achieve an improved biomethane yield. Oxygen assisted hydrothermal pretreatment (at 3 to $9 \% \mathrm{O}_{2}$ loading in the form of $\mathrm{H}_{2} \mathrm{O}_{2}, 180{ }^{\circ} \mathrm{C}$ for $45 \mathrm{~min}$ ) was employed with subsequent anaerobic digestion (with $\mathrm{N}_{2}$ and $\mathrm{CO}_{2}$ at 80:20 ratio) under mesophilic $\left(37^{\circ} \mathrm{C}\right)$ and thermophilic $\left(55^{\circ} \mathrm{C}\right)$ conditions. The effect of pretreatment on the 
composition of OPEFB showed that wet oxidation pretreatment decreases the $\mathrm{pH}$ of OPEFB with increased $\mathrm{O}_{2}$ loading. The $\mathrm{pH}$ of OPEFB mixtures was not reduced below 4, which signifies the absence of inhibitory compounds, demonstrating the suitability of wet oxidation pretreatment on OPEFB prior to anaerobic digestion. Lignin and cellulose content increased slightly, while hemicellulose content was reduced significantly at higher $\mathrm{O}_{2}$ loading. Ahring et al. (2015) noted that a pretreatment would ease the lignocellulose biomass recalcitrance, thereby allowing enzymes to access the biomass surface with ease during anaerobic digestion. The optimum condition for wet oxidation pretreatment on OPEFB was attained at $6 \% \mathrm{O}_{2}$ loading (under mesophilic condition), which led to an increase of $43 \%$ of biomethane yield (corresponding to $\mathrm{ca}$. $86 \%$ of theoretical methane yield) compared to the untreated OPEFB. The study highlighted that anaerobic digestion at thermophilic conditions was responsible for rapidly producing biomethane, attaining a lower yield in comparison to mesophilic conditions. In terms of sustainable assessment, the study evaluated the environmental impact (global warming potential impact) of wet oxidation pretreatment under the lab scale conditions and found that biomethane production under the optimum condition results in $30 \%$ less greenhouse gas emission as opposed to the untreated OPEFB. In conclusion, their study emphasized the potential use of compressed air replacing $\mathrm{H}_{2} \mathrm{O}_{2}$ since $\mathrm{H}_{2} \mathrm{O}_{2}$ and energy demand for wet oxidation pretreatment are significant, which contributes negatively to the global warming potential impact.

Wet oxidation pretreatment cleaves ether linkages present in the alkyl aryl bond by free radicals, which makes it possible to remove the lignin content in lignocellulosic biomass (Abraham et al. 2020).

\section{Supercritical $\mathrm{CO}_{2}$ Explosion}

In supercritical $\mathrm{CO}_{2}$ explosion, $\mathrm{CO}_{2}$ is passed through the biomass under high pressure. Within the biomass, it reacts with water molecules and forms carbonic acid (Zhao et al. 2019), which hydrolyzes the hemicellulose, breaks the compact matrix structure, and exposes the cellulose more to enzymes (Ahmad et al. 2018c). The moisture content of the biomass is a determining factor, as this method is not suitable for biomass with low moisture content (Ahmad et al. 2018b). The non-flammability of $\mathrm{CO}_{2}$, low cost, easy recovery, absence of toxins, and reduced environmental impact are the main advantages of this method. If expansion to an industrial scale is needed, excessive preliminary costs are required for building reactors that can withstand the high pressure of the $\mathrm{CO}_{2}$ (Nlandu et al. 2020).

A dire need persists to implement green and facile technologies for oil palm biomass pretreatment under mild conditions, which is essential towards economic feasibility and environmental sustainability of biorefineries concerning oil palm biomass. Sohni et al. (2020) implemented a novel eco-friendly pretreatment in improving the enzymatic hydrolysis of OPT via supercritical $\mathrm{CO}_{2}$ clean technology for biorefinery application. Supercritical $\mathrm{CO}_{2}$ pretreatment of OPT under mild experimental conditions attained an improved enzymatic digestibility, which offered an optimum sugar yield. The study adopted supercritical $\mathrm{CO}_{2}$ pretreatment conditions of temperature (80 to $120^{\circ} \mathrm{C}$ ), pressure (25 to $45 \mathrm{MPa}$ ), and moisture content held at 0 to $60 \%$ to investigate their effectiveness on enzymatic digestibility of the pretreated OPT samples. Experiments were conducted (along with untreated OPT) at various pretreatment conditions to compare and contrast the effect of each condition on enzymatic hydrolysis. In terms of effect of moisture content of OPT on its changes in chemical composition, they observed that increasing the 
moisture content concurrently enhanced the solubilization of xylan. Supercritical $\mathrm{CO}_{2}$ pretreated OPT obtained a xylan content of $14.3 \%$ as opposed to raw OPT $(22.3 \%)$ at $80{ }^{\circ} \mathrm{C}$, $25 \mathrm{MPa}$ with $60 \%$ moisture content.

Islam et al. (2017b) detailed that pressurized supercritical $\mathrm{CO}_{2}$ and the moisture in biomass combine to form carbonic acid, which accelerates hydrolysis of xylan. It was observed that the temperature had little effect on xylan composition of OPT during supercritical $\mathrm{CO}_{2}$ pretreatment. Benazzi et al. (2013) emphasized that influence of pretreatment temperature on xylan yield is less distinct owing to the solubility of carbon dioxide in the mixture upon increased temperature. The efficiency of supercritical $\mathrm{CO}_{2}$ pretreatment was assessed by carrying out enzymatic hydrolysis of untreated and pretreated OPT samples with the use of Cellic CTec 2 (Novozyme) at $30 \mathrm{FPU} / \mathrm{g}$ loading. Pretreatment conditions of $100{ }^{\circ} \mathrm{C}, 35 \mathrm{MPa}$, and $60 \%$ moisture content resulted in the highest cellulose conversion at $42.8 \%$ compared to untreated OPT $(12.31 \%)$, signifying an effective enzymatic saccharification owing to an effective hydrolysis of hemicellulose content. The study affirmed that hot water in supercritical $\mathrm{CO}_{2}$ application reacted with OPT to promote the disruption of fibers and solubilization of xylan. SEM micrographs revealed that supercritical $\mathrm{CO}_{2}$ pretreatment significantly roughened the OPT biomass surface, creating inhomogeneities and easing the enzyme accessibility towards cellulose. According to the SEM images, it can be highlighted that the extensive surface disruption (reduction in biomass rigidity) at elevated pretreatment temperatures promotes the uptake of $\mathrm{CO}_{2}$ for enhanced enzymatic hydrolysis. Thus, research studies carried out using eco-friendly supercritical $\mathrm{CO}_{2}$ pretreatment could establish next generation oil palm biomass-based biorefineries.

\section{Ammonia Fiber Expansion}

Ammonia fiber expansion pretreatment is a potent strategy to decrease cellulose crystallinity (Moreno et al. 2019). In this process, the lignocellulosic biomass is first mixed with ammonia at a 1:1 ratio. This mixture is then subjected to high pressure $(1.72 \mathrm{MPa}$ to $2.07 \mathrm{MPa}$ ) at a moderate temperature of approximately $60{ }^{\circ} \mathrm{C}$ to $100{ }^{\circ} \mathrm{C}$ for $5 \mathrm{~min}$ to 30 min. The biomass starts swelling due to the high pressure and temperature in the ammonia medium (Latif et al. 2018). Next, the pressure is suddenly released, causing an explosion that breaks down the fibrous structure, resulting in delignification. In the swollen biomass, the crystallinity of cellulose is altered, and accessibility to enzymes is increased (Baruah et al. 2018). Therefore, it can result in better enzymatic hydrolysis with lower enzyme loadings (Ahmad et al. 2018c). Ammonia fiber expansion pretreatment is suitable for biomass containing less lignin. Because it is performed at a moderate temperature, very few inhibitors are formed. Additionally, ammonia can be quickly recovered, so it can be performed as a continuous process and at industrial scale. However, at a commercial scale, the main concern is the odor of the ammonia, which could negatively impact the environment. Moreover, because the pretreatment is performed by pressurizing liquid anhydrous ammonia to high pressure, maintaining tight safety controls is required (Latif et al. 2018).

In contrast to similar alkali pretreatment techniques, pretreatment with ammonia fiber expansion is a "dry to dry" procedure in which sugar degradation is kept to the barest minimum and the amount of ammonia that can be recovered during the pretreatment could be up to $97 \%$. Abdul et al. (2016) studied the structural and chemical characteristics of ammonia fiber expansion pretreatment $\left(135^{\circ} \mathrm{C}, 45 \mathrm{~min}\right.$ residence time and $50 \%$ moisture content) on OPEFB in view of evaluating enzymatic saccharification and fermentability 
for biohydrogen production. They did not observe any sugar loss (glucan, xylan, arabinan) during the solubilization of sugar components in the medium when ammonia fiber expansion pretreatment was applied on OPEFB. The researchers reported that upon $72 \mathrm{~h}$ enzymatic hydrolysis using a combination of Cellic Ctec2® (13.8 FPU/g) and Cellic Htec $2 ®$ enzymes upon ammonia fiber expansion pretreatment attained a total fermentable sugar yield of $0.53 \mathrm{~g}$ per gram of OPEFB compared to $0.15 \mathrm{~g}$ per gram of OPEFB without pretreatment, corresponding to virtually quadruple-fold increase of cellulose conversion. Enzymatic saccharification of pretreated OPEFB under optimum conditions attained a glucan conversion of $90.0 \%$. Authors highlighted that increased total sugar conversion could be related to the removal of physical obstacles including lignin and silica bodies, and improved access of cellulose and hemicellulose in OPEFB to biomass-degrading enzymes through ammonia fiber expansion pretreatment. HPLC analysis of pretreated OPEFB hydrolysate did not detect the presence of any furfural or HMF inhibitors, denoting that detoxification is not required, unlike other pretreatment methods including dilute acid, alkali, liquid hot water, and steam explosion. The presence of such inhibitors retards the microorganism growth during fermentation. Biohydrogen fermentability was examined using Enterobacter sp. KBH6958 bacteria, since this strain enables the production of biohydrogen from both hexose and pentose rich biomasses. $79.8 \%$ of total sugar consumed OPEFB hydrolysate pretreated at optimal conditions produced $50.4 \mathrm{mmol} / \mathrm{L}$ of biohydrogen gas after $72 \mathrm{~h}$ of fermentation.

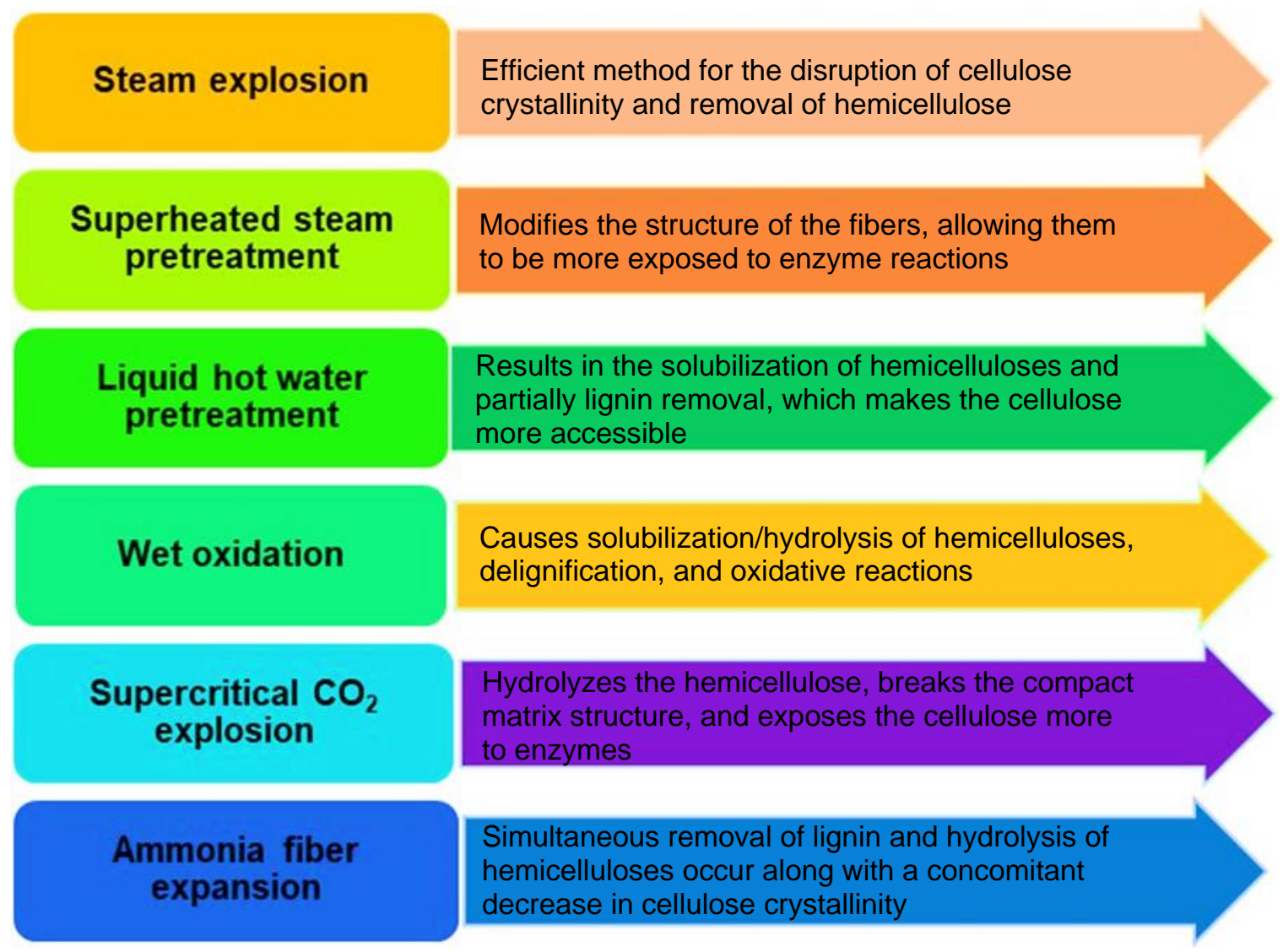

Fig. 6. Major physicochemical pretreatment methods employed on oil palm biomass and their strengths 
As ammonia fiber expansion pretreatment results in practically inhibitory compounds free oil palm biomass residue, subsequent processes get exposed to negligible inhibitor effects, which increases the efficacy of fermentation. Another added advantage of ammonia fiber expansion pretreatment is that it adopts relatively mild conditions (135 ${ }^{\circ} \mathrm{C}$ in this study) as opposed to dilute acid pretreatment (typically 120 to $200{ }^{\circ} \mathrm{C}$ ), liquid hot water pretreatment $\left(140\right.$ to $\left.180^{\circ} \mathrm{C}\right)$, and steam explosion pretreatment $\left(150\right.$ to $\left.260{ }^{\circ} \mathrm{C}\right)$. Moreover, requirement of lesser enzymatic loading and water along with higher ammonia recovery makes ammonia fiber expansion pretreatment a potentially viable approach in terms of pretreatment costs.

Based on the Sustainable Process Index, a metric that measures the environmental sustainability of lignocellulosic biomass pretreatment methods, ammonia fiber expansion is the most ecologically sustainable process for the pretreatment of palm lignocellulosic biomass (Rahman and Amin 2019). Figure 6 illustrates major physicochemical pretreatment methods applied on oil palm biomass residues and their strengths.

Table 4. Overview of Various Physicochemical Pretreatment Methods Employed on Oil Palm Biomass and Their Potential Applications

\begin{tabular}{|c|c|c|c|c|c|c|}
\hline $\begin{array}{l}\text { Pretreatment } \\
\text { Method }\end{array}$ & $\begin{array}{c}\text { Major Agents } \\
\text { Used }\end{array}$ & Conditions & $\begin{array}{l}\text { Oil Palm } \\
\text { Biomass }\end{array}$ & $\begin{array}{l}\text { Concluding } \\
\text { Remarks }\end{array}$ & $\begin{array}{l}\text { Potential } \\
\text { Application }\end{array}$ & Reference \\
\hline $\begin{array}{l}\text { Compressed } \\
\text { hot water }\end{array}$ & $\begin{array}{l}\text { Autoclave } \\
\text { reactor }\end{array}$ & $\begin{array}{l}150^{\circ} \mathrm{C}, \\
20 \mathrm{~min}, \\
400 \mathrm{rpm}\end{array}$ & OPF & $\begin{array}{l}\text { Delignification } \\
\text { of } 23 \%\end{array}$ & - & $\begin{array}{l}\text { Mahmood et } \\
\text { al. (2019) }\end{array}$ \\
\hline $\begin{array}{c}\text { Microwave - } \\
\text { oxalic acid }\end{array}$ & $\begin{array}{l}\text { Digestion } \\
\text { microwave } \\
\text { oven }\end{array}$ & $\begin{array}{c}190^{\circ} \mathrm{C} \\
3 \mathrm{~min}\end{array}$ & OPEFB & $\begin{array}{c}\text { Delignification } \\
\text { of } 50.6 \%\end{array}$ & $\begin{array}{l}\text { Production of } \\
\text { fermentable } \\
\text { sugars }\end{array}$ & $\begin{array}{c}\text { Anita et al. } \\
(2020)\end{array}$ \\
\hline $\begin{array}{l}\text { Pressurized } \\
\text { ammonium } \\
\text { hydroxide }\end{array}$ & $\begin{array}{c}\text { Closed } \\
\text { pressurized } \\
\text { stainless } \\
\text { steel reactor }\end{array}$ & $\begin{array}{c}130^{\circ} \mathrm{C}, \\
1.6 \mathrm{MPa}, \\
30 \mathrm{~min}\end{array}$ & OPEFB & $\begin{array}{c}\text { Delignification } \\
\text { of } 31.6 \%\end{array}$ & $\begin{array}{c}\text { Monomeric } \\
\text { fermentable } \\
\text { sugar } \\
\text { production }\end{array}$ & $\begin{array}{l}\text { Rahman et } \\
\text { al. (2018) }\end{array}$ \\
\hline $\begin{array}{l}\text { Pressurized } \\
\text { anhydrous } \\
\text { ammonia }\end{array}$ & $\begin{array}{l}\text { Bench-top } \\
\text { high- } \\
\text { pressure } \\
\text { Parr reactor }\end{array}$ & \begin{tabular}{|c|}
$135^{\circ} \mathrm{C}$ \\
$3.5-5 \mathrm{MPa}$, \\
$45 \mathrm{~min}$
\end{tabular} & OPEFB & $\begin{array}{c}\text { Delignification } \\
\text { of } 28.0 \%\end{array}$ & $\begin{array}{l}\text { Production of } \\
\text { biohydrogen }\end{array}$ & $\begin{array}{l}\text { Abdul et al. } \\
\text { (2016) }\end{array}$ \\
\hline $\begin{array}{l}\text { Alkali fiber } \\
\text { explosion }\end{array}$ & $\begin{array}{l}\text { Batch } \\
\text { reactor }\end{array}$ & $\begin{array}{c}150^{\circ} \mathrm{C} \\
0.4 \mathrm{MPa}, \\
30 \mathrm{~min}\end{array}$ & OPEFB & $\begin{array}{c}\text { Delignification } \\
\text { of } 30.4 \%\end{array}$ & - & $\begin{array}{c}\text { Waluyo et al. } \\
\text { (2018) }\end{array}$ \\
\hline $\begin{array}{c}\text { Autohydrolysis } \\
\text { / liquid hot } \\
\text { water / } \\
\text { hydrothermal } \\
\text { pretreatment }\end{array}$ & $\begin{array}{c}\text { Autoclave } \\
\text { reactor }\end{array}$ & \begin{tabular}{|c|}
$127.9^{\circ} \mathrm{C}$ \\
$0.15 \mathrm{MPa}$, \\
$60 \mathrm{~min}$
\end{tabular} & OPEFB & $\begin{array}{l}39.1 \% \text { xylose } \\
\text { recovery from } \\
\text { hemicellulose }\end{array}$ & $\begin{array}{c}\text { Production of } \\
\text { xylitol }\end{array}$ & $\begin{array}{c}\text { Harahap and } \\
\text { Kresnowati } \\
(2018)\end{array}$ \\
\hline
\end{tabular}




\begin{tabular}{|c|c|c|c|c|c|c|}
\hline \multirow[t]{5}{*}{$\begin{array}{c}\text { Autohydrolysis } \\
\text { / liquid hot } \\
\text { water / } \\
\text { hydrothermal } \\
\text { pretreatment }\end{array}$} & $\begin{array}{l}\text { Autoclave } \\
\text { reactor }\end{array}$ & $\begin{array}{l}121^{\circ} \mathrm{C}, \\
60 \mathrm{~min}\end{array}$ & OPEFB & $\begin{array}{l}\text { Produced } \\
13.6 \mathrm{~g} / 100 \mathrm{~g} \\
\text { biomass of } \\
\text { reducing } \\
\text { sugars }\end{array}$ & - & $\begin{array}{l}\text { Risanto et al. } \\
\text { (2018) }\end{array}$ \\
\hline & $\begin{array}{l}\text { High-pressure } \\
\text { reactor }\end{array}$ & $\begin{array}{c}2^{\circ} \mathrm{C} / \mathrm{min} \\
185^{\circ} \mathrm{C}, 30 \\
\min \end{array}$ & OPEFB & $\begin{array}{l}\text { Ethanol yield of } \\
\text { approximately } \\
160 \mathrm{~L} / \text { ton dry } \\
\text { fed biomass }\end{array}$ & $\mid \begin{array}{c}\text { Production of } \\
\text { ethanol }\end{array}$ & $\begin{array}{l}\text { Cardona et } \\
\text { al. (2018) }\end{array}$ \\
\hline & $\begin{array}{l}\text { Accelerated } \\
\text { solvent } \\
\text { extractor }\end{array}$ & $\begin{array}{c}200^{\circ} \mathrm{C} \\
20-60 \mathrm{~min}\end{array}$ & OPEFB & $\begin{array}{l}\text { Pretreatment } \\
\text { influenced the } \\
\text { production of } \\
\text { aromatic } \\
\text { chemicals }\end{array}$ & $\begin{array}{c}\text { Production of } \\
\text { protocatechuid } \\
\text { acid } \\
\text { and vanillin }\end{array}$ & $\begin{array}{l}\text { Ramachandran } \\
\text { et al. (2020) }\end{array}$ \\
\hline & $\begin{array}{c}\text { Autoclave } \\
\text { reactor }\end{array}$ & $\begin{array}{l}210^{\circ} \mathrm{C}, \\
30 \mathrm{~min}\end{array}$ & OPF & $\begin{array}{c}\text { Obtained a } \\
\text { fermentable } \\
\text { sugar yield of } \\
48.8 \%(w / v)\end{array}$ & - & $\begin{array}{l}\text { Nadia et al. } \\
(2018 b)\end{array}$ \\
\hline & $\begin{array}{l}\text { Bomb-type } \\
\text { mini-reactor }\end{array}$ & $\begin{array}{l}180^{\circ} \mathrm{C}, \\
30 \mathrm{~min}\end{array}$ & OPT & $\begin{array}{c}81.3 \% \text { of } \\
\text { glucose yield }\end{array}$ & $\begin{array}{c}\text { Production } \\
\text { of ethanol and } \\
\text { fermentable } \\
\text { sugars }\end{array}$ & $\begin{array}{c}\text { Eom et al. } \\
(2015)\end{array}$ \\
\hline
\end{tabular}

\section{BIOLOGICAL PRETREATMENT}

Biological pretreatment methods are eco-friendly, green processes that require no chemicals and do not produce any toxins. They require little equipment and little space (Ummalyma et al. 2019). The methods are substrate-specific, and there are two approaches employed. The first approach uses complete organisms such as bacteria or fungi (Hosseini Koupaie et al. 2019), while the second approach uses enzymes extracted from these organisms or synthesized artificially. The microorganisms used in this process are brownrot, white-rot, and soft-rot fungi (Tian et al. 2018), as well as bacteria. Meanwhile, the enzymes used are lignin peroxidase, versatile peroxidase, manganese peroxidase, and laccases (Noorshamsiana et al. 2017).

Some white-rot fungi can degrade polysaccharides and lignin simultaneously, resulting in the loss of carbohydrates. In contrast, the remaining white-rot fungi are capable of selectively degrading lignin (Amani et al. 2018). Cellulolytic and lignolytic systems are the two extracellular enzymatic systems involved in microorganism pretreatment (Tsegaye et al. 2019). The cellulolytic system is responsible for degrading cellulose and hemicelluloses, while the lignolytic system is responsible for depolymerizing lignin. Drawbacks of biological pretreatment include the slower rate of conversion and the cost of enzymes (Sasmal and Mohanty 2018). Table 5 describes some previous studies of oil palm biomass employing various biological pretreatment methods, including the reaction conditions that were applied and the outcome of each technique.

Biological pretreatment promotes lignin removal in lignocellulosic biomass via microbial enzymes, which promotes its digestion. Even though biological pretreatment 
strategies apply mild conditions compared to chemical pretreatment methods, pretreatment requires much longer times as opposed to other means of pretreatment (Abraham et al. 2020).

\section{Whole-cell/Microorganism Pretreatment}

Fungi are the most used type of microorganism, as they can degrade hemicellulose and lignin. Of the fungi, white-rot fungi are frequently used (Ahmad et al. 2018c), as they have the greatest ability to degrade lignin (Nadia et al. 2018a). They can produce enzymes such as laccase, lignin peroxidase, manganese peroxidase (Ding et al. 2019), and phenol oxidases (Ahmad et al. 2018c). Some commonly used fungal species are Phanerochaete chrysosporium (Amani et al. 2018; Ummalyma et al. 2019), Pleurotus ostreatus, Cyathus stercoreus (Cherukuri and Akkina 2019), Ceriporia lacerata, Ceriporiopsis subvermispora, Pycnoporus cinnabarinus (Arora et al. 2019), Laetiporus sulphureus, Coniophora puteana, Serpula lacrymans, Gloeophyllum trabeum, and Daldinia concentrica (Tsegaye et al. 2019). White-rot fungi can selectively degrade lignin and have lignolytic function (Ding et al. 2019), whereas brown-rot fungi have the greatest ability to break down cellulose and have the hydrolytic role (Tsegaye et al. 2019). The biomass composition, particle size, $\mathrm{pH}$ of the medium, reaction time, and microorganism involved play important roles in these reactions (Sharma et al. 2019). This process is eco-friendly, as it does not produce any toxins, and the recovery of sugar is high, as it does not produce any inhibitors that affect the fermentation step. The energy input and amount of chemicals needed are low, and the methods are substrate-specific (Baruah et al. 2018). However, the process is not feasible at the industrial scale, as it is relatively slow and requires specialized knowledge in handling the microorganisms. In a study performed by Amani et al. (2018), $P$. chrysosporium CK 1 was used as the pretreatment agent, which resulted in approximately $51 \%$ lignin removal. Similar results were obtained in a study using Schizophyllum commune ENN1, which resulted in 53.8\% lignin removal (Arbaain et al. 2019).

\section{Enzymatic Pretreatment}

Enzymatic pretreatment is a biological pretreatment technique that has gained considerable interest in the recent past for improved production of biogas from lignocellulosic biomass. Enzymatic pretreatment has the potential to enhance the anaerobic digestion process to maximize biogas production. There are two main types of enzymes used: laccase and peroxidase (Hosseini Koupaie et al. 2019). Peroxidases include lignin peroxidase, manganese peroxidase, and versatile peroxidase (Ding et al. 2019). Laccase catalyzes the phenolic substructure of lignin. The peroxides are heme-containing glycoproteins that require hydrogen peroxide $\left(\mathrm{H}_{2} \mathrm{O}_{2}\right)$ as an oxidant. Lignin peroxidase generally oxidizes non-phenolic lignin, whereas manganese peroxidase catalyzes manganese-dependent reactions. Manganese peroxidase oxidizes lignin's phenolic ring, which has a vital role in the initial stage of lignin degradation (Tsegaye et al. 2019). Versatile peroxidase, as the name implies, oxidizes both non-phenolic and phenolic aromatic compounds. Thus, versatile peroxidase enzymes have the catalytic activities of both lignin peroxidase and manganese peroxidase (Baruah et al. 2018).

Enzymatic pretreatment is an eco-friendly process, has a comparatively short reaction time, and does not require costly equipment to perform. However, the main disadvantage is its dependency on enzymes, considerably increasing the costs of the process if it is expanded to an industrial scale (Hosseini Koupaie et al. 2019). 
Apart from biological pretreatment, other pretreatment techniques employ enzymes as a co-digestion, in which chemical pretreatment approaches utilize harsh conditions, which cause environmental issues. As an effective pretreatment breaks down the complex biomass structure into monomers, microbes could grow on them in achieving an increased anerobic digestion rate. Islam et al. (2017a) employed enzymatic pretreatment on POME towards biogas production. Enzymatic pretreatment is a green approach to overcome the recalcitrance of oil palm biomass. Even though it is eco-friendly, a high cost of application is a real concern. Thus, current studies are focused on reducing the costs associated with purchase of enzymes. Their study utilized locally produced hydrolytic enzymes (cellulase and lipase) to investigate the effect of pretreatment and hydrolysis on biogas production. Lipase loading on the production of free fatty acids (FFA) revealed that a significant rise in FFA content was observed upon lipase loading from $3 \mathrm{U} / \mathrm{mL}$ to $15 \mathrm{U} / \mathrm{mL}$. Enzyme contact time with the substrate positively affected the production of FFA in which a pronounced increment in FFA was observed upon increases contact time (from 1 to $6 \mathrm{~h}$ ). A high cellulase loading attained a substantial enhancement in reducing sugar yield, similarly, effect of cellulase activity (until 2.4 FPU/mL) enhanced the reducing sugar yield.

Table 5. Overview of Various Biological Pretreatment Methods Employed On Oil Palm Biomass and Their Potential Applications

\begin{tabular}{|c|c|c|c|c|c|c|}
\hline $\begin{array}{l}\text { Pretreatment } \\
\text { Method }\end{array}$ & $\begin{array}{l}\text { Major Agents } \\
\text { Used }\end{array}$ & Conditions & $\begin{array}{l}\text { Oil Palm } \\
\text { Biomass }\end{array}$ & $\begin{array}{l}\text { Concluding } \\
\text { Remarks }\end{array}$ & $\begin{array}{l}\text { Potential } \\
\text { Application }\end{array}$ & Reference \\
\hline \multirow[t]{4}{*}{$\begin{array}{l}\text { Microorganism } \\
\text { pretreatment }\end{array}$} & $\begin{array}{c}\text { Pseudomonas } \\
\text { sp. }\end{array}$ & $\begin{array}{c}\text { Inoculated in } \\
\text { Luria-Bertani } \\
\text { liquid medium, } \\
\mathrm{pH} 7.5,30^{\circ} \mathrm{C} \text {, } \\
24 \mathrm{~h}\end{array}$ & $\begin{array}{l}\text { Palm oil } \\
\text { mill effluent } \\
\text { (POME) }\end{array}$ & $\begin{array}{l}59.1 \% \text { color } \\
\text { degradation } \\
\text { of POME }\end{array}$ & $\begin{array}{l}\text { Production } \\
\text { of biofuel }\end{array}$ & $\begin{array}{l}\text { Cheah } \\
\text { et al. } \\
(2018)\end{array}$ \\
\hline & \begin{tabular}{|c|}
$P$. \\
chrysosporium \\
CK 1
\end{tabular} & $\begin{array}{l}\text { Inoculated in } \\
\text { Japanese } \\
\text { Industrial } \\
\text { Standard (JIS) } \\
\text { broth medium, } \\
30^{\circ} \mathrm{C}, 3 \\
\text { weeks }\end{array}$ & OPF & $\begin{array}{l}51 \% \\
\text { lignin } \\
\text { removal }\end{array}$ & $\begin{array}{l}\text { Production } \\
\text { of } \\
\text { bioethanol }\end{array}$ & $\begin{array}{l}\text { Amani } \\
\text { et al. } \\
(2018)\end{array}$ \\
\hline & $\begin{array}{c}\text { Schizophyllum } \\
\text { commune } \\
\text { ENN1 }\end{array}$ & $\begin{array}{c}\text { Inoculated with } \\
5 \text { agar plugs, } \\
14 \mathrm{~d}, 30^{\circ} \mathrm{C}\end{array}$ & OPEFB & $\begin{array}{l}53.8 \% \\
\text { lignin } \\
\text { removal }\end{array}$ & - & $\begin{array}{l}\text { Arbaain } \\
\text { et al. } \\
\text { (2019) }\end{array}$ \\
\hline & Bacillus sp. & $\begin{array}{l}\text { Inoculated in } \\
\text { Luria broth, pH } \\
6.5,35^{\circ} \mathrm{C}, 7 \mathrm{~d}\end{array}$ & OPEFB & $\begin{array}{l}\text { High tensile } \\
\text { index of } \\
7.14 \mathrm{~N} \cdot \mathrm{m} / \mathrm{g}\end{array}$ & $\begin{array}{l}\text { Production } \\
\text { of pulp and } \\
\text { paper }\end{array}$ & $\begin{array}{l}\text { Syarifah } \\
\text { et al. } \\
\text { (2019) }\end{array}$ \\
\hline
\end{tabular}

\section{COMBINATION OF PRETREATMENT METHODS}

Currently, many researchers are interested in using multiple pretreatment methods simultaneously (Hassan et al. 2018; Ummalyma et al. 2019). Such techniques are able to eliminate the adverse effects of each process while enhancing their positive features (Zhai et al. 2018). The combination of pretreatment methods is able to increase the final sugar yield considerably, as the fiber structure changes in each step, increasing the surface area. 
Thereby, upon further hydrolysis, the production of ethanol is increased compared to the amount produced after isolated pretreatment steps (Thamsee et al. 2019). Commonly combined pretreatment methods include steam explosion and biological pretreatment, biological and mild acid pretreatment, liquid hot water and biological pretreatment, and ultrasonic and biological pretreatment (Ummalyma et al. 2019). Sun et al. (2016) in their review study deliberated that combined pretreatment strategies improve the ease of access of enzymes to cellulose (i.e. enhanced enzymatic hydrolysis) and expedite the recovery of hemicellulose and lignin associated in producing value-added products.

Currently, microwave pretreatment is one of the common methods combined with other treatment methods. Researchers have combined microwave pretreatment with methods such as alkaline pretreatment (Megashah et al. 2018b), ultrasound (Hassan et al. 2018), ionic liquid pretreatment, autohydrolysis (Rigual et al. 2018), and hydrothermal pretreatment (López-Linares et al. 2019). The ruptured fibers from microwave pretreatment are easily accessible to chemicals, which can then penetrate the innermost parts of the fibers and increase the delignification (López-Linares et al. 2019). Wet disk milling has also been combined with other pretreatment methods to increase the yield of sugar produced (Peinemann and Pleissner 2020). Many studies have been performed that employ a combination of pretreatment methods. Table 6 describes some previous studies on different combination pretreatment methods for oil palm biomass, including the reaction conditions and outcomes.

Effective low-cost pretreatment methods not only affect the recalcitrant properties of lignocellulosic biomass, but also aid in reutilizing the cellulosic content within the biomass to convert into value-added products. Ho and co-workers (2019) employed low concentration alkaline $\mathrm{H}_{2} \mathrm{O}_{2}$ at non-severe pretreatment conditions along with deep eutectic solvent (choline chloride: urea) to enhance the delignification of OPF. Sequential pretreatment of alkaline hydrogen peroxide (AHP) $(0.05$ to $1.00 \mathrm{vol} \%, 90 \mathrm{~min})$ together with DES $\left(120{ }^{\circ} \mathrm{C}, 4 \mathrm{~h}\right)$ resulted in a delignification of $19.0 \%$, signifying a notable improvement (1.56 fold) in delignification compared to the pretreatment with DES alone (control). The study revealed that AHP pretreatment alone was effective in delignifying OPF even with mild alkaline concentration. For instance, 1.00 vol\% AHP pretreatment achieved a delignification of $12.8 \%$ as opposed to the delignification attained using DES alone $(12.2 \%)$. Even though higher concentrations of AHP enhanced the lignin removal efficiency, higher consumption of $\mathrm{H}_{2} \mathrm{O}_{2}$ and $\mathrm{NaOH}$ is not economically viable at industrial scale in addition to environmental concerns. Considering the overall delignification efficiency at a fixed DES pretreatment condition, 0.25 vol\% of AHP was selected as the optimum condition without causing any adverse effects on subsequent DES delignification. At higher AHP concentration ( $>0.25$ vol\%\%), lignin removal adopting sequential pretreatment was not effective, which could be as a result of high accumulation of hydroxide ions hindering DES delignification.

Mittal et al. (2017) underlined that a severe AHP pretreatment may mitigate the approachability of lignocellulosic biomass owing to the breakdown of localized cell wall, leading to ineffective conversion of sugars. Ho et al. (2019) obtained a glucan enrichment of 54.4\% upon synergistic combination of AHP and DES pretreatment on OPF, which was more than the individual AHP (49.0\%) and DES (50.3\%) pretreatments. SEM micrographs revealed that sequential pretreatment ruptured the complex structure of OPF, improving the ease of access to cellulose. BET analysis demonstrated that AHP+DES pretreated OPF attained the highest surface area of $0.512 \mathrm{~m}^{2} / \mathrm{g}$ among all the tested samples (an increment of $18.7 \%$ surface area compared to untreated OPF), signifying the highest delignification. 
Since combined AHP and DES pretreatment was able to achieve a delignification of only $19.0 \%$, it can be concluded that further enhancement in the effectiveness of DES pretreatment is required in order attain a potent synergistic effect through sequential pretreatment.

Ong et al. (2019) employed successive ultrasonication and DES pretreatment for the removal of lignin and to recover xylose from OPF. OPF samples were subjected ultrasonication in a water medium with subsequent DES (choline chloride: urea) pretreatment. Optimum ultrasonication conditions were found to be $70 \%$ amplitude for a 30 min time duration. A lignin removal of $36.4 \%$ was attained under mild pretreatment conditions along with a xylose recovery up to 58\%. During the ultrasonication pretreatment, water was used as the reaction medium without using DES since highly viscous DES mixture would retard the formation and growth of microbubbles. It was proposed that initial application of ultrasonication degrades the complex lignin structure, which in turn improves the exposure of lignin in enhancing the efficacy of DES pretreatment. The study demonstrated that enhanced severity of ultrasound increased the synergistic effect when the two pretreatment techniques are employed sequentially. Since ultrasound severity positively affected the delignification, duration and amplitude of ultrasound should be optimized in such a way that it is sufficient to disrupt the biomass recalcitrance.

Table 6. Overview of Various Combined Pretreatment Methods Employed on Oil Palm Biomass and Their Potential Applications

\begin{tabular}{|c|c|c|c|c|c|c|}
\hline $\begin{array}{l}\text { Pretreatment } \\
\text { Methods }\end{array}$ & $\begin{array}{l}\text { Major Agents } \\
\text { Used }\end{array}$ & Conditions & \begin{tabular}{|l|} 
Oil Palm \\
Biomass
\end{tabular} & $\begin{array}{l}\text { Concluding } \\
\text { Remarks }\end{array}$ & $\begin{array}{l}\text { Potential } \\
\text { Application }\end{array}$ & Reference \\
\hline $\begin{array}{c}\text { Steam } \\
\text { explosion with } \\
\text { alkaline } \\
\text { delignification }\end{array}$ & $\begin{array}{l}2.5 \text { wt\% } \\
\mathrm{NaOH}, \\
\text { steam } \\
\text { explosion } \\
\text { reactor }\end{array}$ & $\begin{array}{c}\text { Steam explosion: } \\
175^{\circ} \mathrm{C}, 10 \mathrm{~min} \\
\text { Alkaline } \\
\text { delignification: } \\
121^{\circ} \mathrm{C}, 80 \mathrm{~min}\end{array}$ & OPEFB & $\begin{array}{l}28.4 \% \\
\text { removal of } \\
\text { lignin }\end{array}$ & $\begin{array}{l}\text { Feedstock } \\
\text { for } \\
\text { biorefinery } \\
\text { processes }\end{array}$ & $\begin{array}{l}\text { Medina et } \\
\text { al. (2018) }\end{array}$ \\
\hline $\begin{array}{l}\text { Hot water with } \\
\text { alkaline } \\
\text { pretreatment }\end{array}$ & $\begin{array}{l}2.5 \mathrm{M} \\
\mathrm{NaOH}\end{array}$ & $\begin{array}{l}\text { Hot water: } 60 \\
\text { min at } 80^{\circ} \mathrm{C} \\
\\
\text { Alkaline } \\
\text { delignification: } \\
121^{\circ} \mathrm{C}, 15 \mathrm{~min}\end{array}$ & OPEFB & $\begin{array}{c}30 \% \text { and } 56 \% \\
\text { removals of } \\
\text { lignin and } \\
\text { hemicelluloses, } \\
\text { respectively }\end{array}$ & $\begin{array}{l}\text { Production } \\
\text { of reducing } \\
\text { sugars }\end{array}$ & $\begin{array}{l}\text { Ghazali } \\
\text { and } \\
\text { Makhtar } \\
(2018)\end{array}$ \\
\hline $\begin{array}{c}\text { Microwave } \\
\text { assisted acid } \\
\text { pretreatment }\end{array}$ & $\begin{array}{c}\text { Microwaves, } \\
\text { glycerol, } \\
\mathrm{H}_{2} \mathrm{SO}_{4}\end{array}$ & $\begin{array}{c}\text { Glycerol: } \mathrm{H}_{2} \mathrm{SO}_{4}, \\
2: 1 \\
\text { at } 1 \% \mathrm{H}_{2} \mathrm{SO}_{4} \\
\\
\text { Microwave: } 2450 \\
\text { MHz, } 550 \mathrm{~W} \\
12.5 \mathrm{~min}\end{array}$ & OPEFB & $\begin{array}{c}59.2 \% \text { removal } \\
\text { of } \\
\text { lignin and } \\
\text { reducing sugar } \\
\text { yield of } 55.8 \% \\
\text { per pretreated } \\
\text { OPEFB }\end{array}$ & $\begin{array}{c}\text { Production of } \\
\text { fermentable } \\
\text { sugars }\end{array}$ & $\begin{array}{c}\text { Fatriasari } \\
\text { et al. } \\
(2017)\end{array}$ \\
\hline
\end{tabular}




\begin{tabular}{|c|c|c|c|c|c|c|}
\hline $\begin{array}{l}\text { Microwave } \\
\text { assisted } \\
\text { maleic acid } \\
\text { pretreatment }\end{array}$ & $\begin{array}{l}\text { Microwaves, } \\
\text { maleic acid }\end{array}$ & $\begin{array}{c}1 \% \text { maleic acid } \\
\text { Microwave: } \\
1000 \mathrm{~W}, 2.5 \\
\text { min, } 190^{\circ} \mathrm{C}\end{array}$ & OPEFB & \begin{tabular}{|c|}
$22.4 \%$ \\
removal of \\
lignin and \\
reducing sugar \\
yield of $47.2 \%$ \\
per pretreated \\
OPEFB
\end{tabular} & $\begin{array}{l}\text { Production of } \\
\text { bioethanol }\end{array}$ & $\begin{array}{c}\text { Fatriasari } \\
\text { et al. } \\
(2018)\end{array}$ \\
\hline $\begin{array}{l}\text { SHS with } \\
\text { laccase } \\
\text { pretreatment }\end{array}$ & $\begin{array}{c}0.05 \mathrm{M} \\
\text { sodium } \\
\text { acetate } \\
\text { buffer, } \\
\text { T. versicolor } \\
100 \mathrm{U} / \mathrm{g} \\
\text { substrate } \\
0.05 \mathrm{M} \\
\text { sodium } \\
\text { acetate } \\
\text { buffer, } \\
\text { T. versicolor } \\
400 \mathrm{U} / \mathrm{g} \\
\text { substrate } \\
\end{array}$ & $\begin{array}{c}\text { SHS: } 6.6 \mathrm{~kW}, \\
4.95 \mathrm{~kg} / \mathrm{h}, 180 \\
{ }^{\circ} \mathrm{C}, 60 \mathrm{~min} \\
\\
\text { Laccase: } \mathrm{pH} \\
4.8,150 \mathrm{rpm}, \\
50^{\circ} \mathrm{C}, 24 \mathrm{~h} \\
\mathrm{SHS}: 6.6 \mathrm{~kW}, \\
4.95 \mathrm{~kg} / \mathrm{h}, 190 \\
{ }^{\circ} \mathrm{C}, 60 \mathrm{~min} \\
\\
\text { Laccase: } \mathrm{pH} \\
4.8,150 \mathrm{rpm}, \\
50{ }^{\circ} \mathrm{C}, 24 \mathrm{~h}\end{array}$ & OPEFB & $\begin{array}{l}39.6 \% \\
\text { removal of } \\
\text { lignin }\end{array}$ & $\begin{array}{l}\text { Production of } \\
\text { fermentable } \\
\text { sugars }\end{array}$ & $\begin{array}{c}\text { Rizal et } \\
\text { al. } \\
(2018 b)\end{array}$ \\
\hline $\begin{array}{c}\text { Alkaline } \\
\text { pretreatment } \\
\text { with } \\
\text { ultrasonication }\end{array}$ & $\begin{array}{c}6 \%(\mathrm{w} / \mathrm{v}) \\
\mathrm{NaClO}_{2} \text { and } \\
\mathrm{KOH}, \\
\text { ultrasonicator }\end{array}$ & $\begin{array}{l}\text { Ultrasonication: } \\
125 \mathrm{~W}, 20 \mathrm{kHz} \text {, } \\
100 \mathrm{amp}, 9 \mathrm{~h}\end{array}$ & OPMF & $\begin{array}{c}\text { Crystallinity: } \\
41 \%\end{array}$ & $\begin{array}{c}\text { Manufacture } \\
\text { of } \\
\text { transparent } \\
\text { paper }\end{array}$ & $\begin{array}{l}\text { Yasim- } \\
\text { Anuar et } \\
\text { al. (2018) }\end{array}$ \\
\hline $\begin{array}{l}\text { Electron beam } \\
\text { irradiation and } \\
\text { ionic liquid } \\
\text { pretreatment }\end{array}$ & $\begin{array}{c}\text { Electron } \\
\text { beam } \\
\text { accelerator, } \\
50 \text { vol\% of } \\
{[\text { EMIM][OAc] }}\end{array}$ & $\begin{array}{l}\text { Irradiation: } 800 \\
\text { kGy, } 3 \mathrm{MeV} \\
\\
\text { Ionic liquid: } 99 \\
{ }^{\circ} \mathrm{C}, 4 \mathrm{~h}, 800 \\
\text { rpm }\end{array}$ & OPF & $\begin{array}{c}\text { Crystallinity: } \\
54.92 \%\end{array}$ & $\begin{array}{l}\text { Production } \\
\text { of } \\
\text { bioethanol }\end{array}$ & $\begin{array}{c}\text { Jusri et al. } \\
\text { (2019) }\end{array}$ \\
\hline $\begin{array}{c}\text { Organic } \\
\text { scavenger } \\
\text { pretreatment } \\
\text { with } \\
\text { autohydrolysis }\end{array}$ & \begin{tabular}{|c|}
$15 \%(\mathrm{w} / \mathrm{v}) \mathrm{p}-$ \\
hydroxyaceto \\
phenone \\
$(\mathrm{BDH})$, \\
stainless steel \\
pressure \\
reactor
\end{tabular} & $\begin{array}{c}\text { Organic } \\
\text { scavenger: } 30 \\
{ }^{\circ} \mathrm{C}, 15 \mathrm{~min} \\
\text { Autohydrolysis: } 6 \\
\text { h, } 150^{\circ} \mathrm{C}\end{array}$ & OPF & $\begin{array}{c}\text { Produced lignin } \\
\text { with } \\
\text { improved } \\
\text { thermal stability } \\
\text { and antioxidant } \\
\text { activity }\end{array}$ & $\begin{array}{c}\text { As } \\
\text { antioxidants }\end{array}$ & $\begin{array}{l}\text { Latif et al. } \\
\quad(2019)\end{array}$ \\
\hline $\begin{array}{l}\text { Steam-alkali- } \\
\text { chemical } \\
\text { pretreatment }\end{array}$ & $\begin{array}{c}2.5 \mathrm{M} \\
\mathrm{NaOH}, \\
\text { autoclave }\end{array}$ & $\begin{array}{c}\text { Autoclaving: } \\
121^{\circ} \mathrm{C}, 15 \\
\min , 0.12 \mathrm{MPa}\end{array}$ & OPT & $\begin{array}{l}\text { Removal of } \\
89.4 \% \text { of } \\
\text { lignin }\end{array}$ & Production & Lai and \\
\hline $\begin{array}{l}\text { Microwave- } \\
\text { alkali } \\
\text { pretreatment }\end{array}$ & $\begin{array}{l}\text { Microwaves, } \\
2.5 \mathrm{M} \mathrm{NaOH}\end{array}$ & $\begin{array}{c}700 \mathrm{~W}, 80^{\circ} \mathrm{C}, \\
60 \mathrm{~min}\end{array}$ & OPT & $\begin{array}{l}\text { Removal of } \\
15.3 \% \text { of } \\
\text { lignin }\end{array}$ & of glucose & $\begin{array}{l}\text { Idris } \\
(2016)\end{array}$ \\
\hline
\end{tabular}




\begin{tabular}{|c|c|c|c|c|c|c|}
\hline $\begin{array}{c}\text { Alkaline } \\
\text { hydrogen } \\
\text { peroxide (AHP) } \\
\text { with DES } \\
\text { pretreatment }\end{array}$ & $\begin{array}{c}0.25 \%(\mathrm{v} / \mathrm{v}) \text { of } \\
\mathrm{H}_{2} \mathrm{O}_{2}, \mathrm{NaOH}, \\
\text { choline } \\
\text { chloride, urea }\end{array}$ & $\begin{array}{c}\mathrm{AHP}: \mathrm{pH}=11.5, \\
90 \mathrm{~min}, 25{ }^{\circ} \mathrm{C} \\
\mathrm{DES}: \mathrm{ChCl}: \\
\mathrm{Urea}, 1: 2,120 \\
{ }^{\circ} \mathrm{C}, 4 \mathrm{~h}\end{array}$ & OPF & $\begin{array}{c}19.0 \% \\
\text { removal of } \\
\text { lignin }\end{array}$ & $\begin{array}{c}\text { Potential } \\
\text { feedstock for } \\
\text { biorefinery } \\
\text { processes }\end{array}$ & $\begin{array}{c}\text { Ho et al. } \\
(2019)\end{array}$ \\
\hline $\begin{array}{c}\text { Sequential } \\
\text { ultrasonication } \\
\text { and DES } \\
\text { pretreatment }\end{array}$ & $\begin{array}{c}\text { Choline } \\
\text { chloride, urea, } \\
\text { ultrasonicator } \\
\text { coupled with } \\
\text { a cup horn }\end{array}$ & $\begin{array}{c}\text { Ultrasonication: } \\
70 \% \text { amplitude, } \\
30 \text { min }\end{array}$ & $\begin{array}{c}\text { OPF } \\
\text { DES: } \mathrm{ChCl}: \\
\text { Urea, } 1: 2,120 \\
{ }^{\circ} \mathrm{C}, 4 \mathrm{~h}\end{array}$ & $\begin{array}{c}36.4 \% \\
\text { removal of } \\
\text { lignin }\end{array}$ & $\begin{array}{c}\text { Enhanced } \\
\text { xylose } \\
\text { recovery from } \\
\text { OPF }\end{array}$ & $\begin{array}{c}\text { Ong et al. } \\
(2019)\end{array}$ \\
& & & & \\
& & & & \\
\end{tabular}

There are various biochemical technologies including fermentation (enzymatic hydrolysis), esterification, anaerobic digestion, photosynthetic organisms, and dark fermentation processes to valorize oil palm biomass into value-added products such as biodiesel, syngas, bioethanol, biochar, and biogas (Mun 2015; Onoja et al. 2019). Upon attaining cellulose through a disruptive pretreatment process, cellulose can be converted to simple sugars (glucose, fructose, and galactose) via enzymatic hydrolysis in producing value-added products (Lim et al. 2016). Increasing the accessible surface area of the oil palm biomass residues promotes the adsorption of microbes or enzymes with high efficacy, whereas decrystallization of cellulose and the removal of both lignin and hemicellulose under anaerobic conditions enhances the digestion. It has been highlighted that anaerobic digestion is an efficient process to attain sustainable energy production (Abraham et al. 2020).

\section{COMPARATIVE ANALYSIS}

Of the examined research articles, some tested different pretreatment methods on a particular type of oil palm biomass (Table 7), while others tested a particular pretreatment method on different types of oil palm biomass (Table 8). Comparing these studies reveals a relationship between the pretreatment performed and the amount of lignin present in the studied biomass: When greater amounts of lignin are present, harsher conditions should be used. Additionally, coupling different pretreatment methods could decrease the amount of lignin, making the biomass considerably more vulnerable to further reactions. Waluyo et al. (2018) employed alkali pretreatment and alkali fiber explosion on OPEFB. The delignification increased to $30.4 \%$ when applying high pressure with increased temperature, even with a decreased concentration $(12 \%)$ of $\mathrm{NaOH}$. In contrast, with a greater $\mathrm{NaOH}$ concentration $(15 \%)$ at atmospheric pressure and temperature, the delignification was $5.30 \%$. Thus, the study shows that chemical pretreatment, when coupled with increased physical conditions, leads to better delignification.

Mahmood et al. (2019) tested acid pretreatment, alkali pretreatment, ionic liquid pretreatment, and hot compressed water pretreatment on OPF. Ionic pretreatment yielded the greatest delignification but required a longer reaction time. Due to the low toxicity and recyclability of ionic liquids, this could be a better alternative when expanding to industrial scale. A different strategy was used by Thamsee et al. (2018), who used the same pretreatment method on different types of oil palm biomass. The lignin contents of the different biomass types were slightly different: $14.25 \% \pm 1.30 \%$ in OPEFB, $16.74 \% \pm$ 
$1.40 \%$ in OPF, and $15.02 \% \pm 0.78 \%$ in OPT. This led to slight variations in the amounts of lignin remaining after pretreatment: $11.73 \%, 9.83 \%$, and $10.99 \%$ in OPEFB, OPF, and OPT, respectively.

Table 7. Different Pretreatment Methods Performed on Particular Types of Oil Palm Biomass

\begin{tabular}{|c|c|c|c|c|c|c|}
\hline $\begin{array}{l}\text { Pretreatment } \\
\text { Method }\end{array}$ & $\begin{array}{c}\text { Major Agents } \\
\text { Used }\end{array}$ & Conditions & $\begin{array}{l}\text { Oil Palm } \\
\text { Biomass }\end{array}$ & $\begin{array}{l}\text { Concluding } \\
\text { Remarks }\end{array}$ & $\begin{array}{c}\text { Potential } \\
\text { Application }\end{array}$ & Reference \\
\hline $\begin{array}{c}\text { Acid } \\
\text { pretreatment }\end{array}$ & $\begin{array}{c}2.5 \text { wt } \% \text { acetic } \\
\text { acid }\end{array}$ & $\begin{array}{c}120.2^{\circ} \mathrm{C} \\
0.1 \mathrm{MPa}, 15 \\
\min \end{array}$ & \multirow{3}{*}{ OPEFB } & $\begin{array}{l}13 \% \text { xylose } \\
\text { recovery from } \\
\text { hemicellulose }\end{array}$ & \multirow{3}{*}{$\begin{array}{l}\text { Production } \\
\text { of xylitol }\end{array}$} & \multirow{3}{*}{$\begin{array}{l}\text { Harahap } \\
\text { and } \\
\text { Kresnowati } \\
\text { (2018) }\end{array}$} \\
\hline $\begin{array}{c}\text { Alkaline } \\
\text { pretreatment }\end{array}$ & $5 \mathrm{wt} \% \mathrm{NH}_{3}$ & $\begin{array}{l}120.2^{\circ} \mathrm{C}, 0.1 \\
\mathrm{MPa}, 15 \mathrm{~min}\end{array}$ & & $\begin{array}{l}19.2 \% \text { xylose } \\
\text { recovery from } \\
\text { hemicellulose }\end{array}$ & & \\
\hline Autohydrolysis & $\begin{array}{l}\text { Autoclave } \\
\text { reactor }\end{array}$ & $\begin{array}{c}127.9^{\circ} \mathrm{C} \\
0.15 \mathrm{MPa}, 60 \\
\min \end{array}$ & & $\begin{array}{l}39.1 \% \text { xylose } \\
\text { recovery from } \\
\text { hemicellulose }\end{array}$ & & \\
\hline $\begin{array}{c}\text { Alkaline } \\
\text { pretreatment }\end{array}$ & $\begin{array}{c}15 \%(\mathrm{w} / \mathrm{v}) \\
\mathrm{NaOH}\end{array}$ & $\begin{array}{c}\text { Atmospheric } \\
\text { temperature } \\
\text { and pressure, } \\
24 \mathrm{~h}\end{array}$ & \multirow{2}{*}{ OPEFB } & $\begin{array}{c}\text { Delignification } \\
\text { of } 5.30 \%\end{array}$ & \multirow{2}{*}{-} & \multirow{2}{*}{$\begin{array}{l}\text { Waluyo } \\
\text { et al. } \\
(2018)\end{array}$} \\
\hline $\begin{array}{l}\text { Alkali fiber } \\
\text { explosion }\end{array}$ & $\begin{array}{l}12 \%(\mathrm{w} / \mathrm{v}) \\
\mathrm{NaOH} \text { batch } \\
\text { reactor }\end{array}$ & $\begin{array}{r}150^{\circ} \mathrm{C}, 0.4 \\
\mathrm{MPa}, 30 \mathrm{~min}\end{array}$ & & $\begin{array}{c}\text { Delignification } \\
\text { of } 30.4 \%\end{array}$ & & \\
\hline $\begin{array}{c}\text { Acid } \\
\text { pretreatment }\end{array}$ & $\begin{array}{c}1.82 \mathrm{wt} \% \\
\mathrm{H}_{2} \mathrm{SO}_{4}\end{array}$ & $\begin{array}{c}140^{\circ} \mathrm{C}, 20 \\
\min , 400 \mathrm{rpm}\end{array}$ & \multirow{4}{*}{ OPF } & $\begin{array}{l}\text { Delignification } \\
\text { of } 23 \%\end{array}$ & - & \multirow{4}{*}{$\begin{array}{l}\text { Mahmood } \\
\text { et al. }(2019\end{array}$} \\
\hline $\begin{array}{c}\text { Alkaline } \\
\text { pretreatment }\end{array}$ & $2 \mathrm{wt} \% \mathrm{NaOH}$ & $\begin{array}{c}150^{\circ} \mathrm{C}, 30 \\
\mathrm{~min}, 400 \mathrm{rpm}\end{array}$ & & $\begin{array}{c}\text { Delignification } \\
\text { of } 31 \%\end{array}$ & - & \\
\hline Ionic liquid & [EMIM][DEP] & $\begin{array}{c}90^{\circ} \mathrm{C}, 3 \mathrm{~h}, \\
500 \mathrm{rpm}\end{array}$ & & $\begin{array}{c}\text { Delignification } \\
\text { of } 62 \%\end{array}$ & $\begin{array}{c}\text { Biofuels and } \\
\text { biocomposites }\end{array}$ & \\
\hline $\begin{array}{l}\text { Compressed } \\
\text { hot water }\end{array}$ & $\begin{array}{l}\text { Autoclave } \\
\text { reactor }\end{array}$ & $\begin{array}{c}150^{\circ} \mathrm{C}, 20 \\
\mathrm{~min}, 400 \mathrm{rpm}\end{array}$ & & $\begin{array}{l}\text { Delignification } \\
\text { of } 23 \%\end{array}$ & - & \\
\hline
\end{tabular}

Meanwhile, Rizal et al. (2018a) experimented on OPEFB and OPMF that had a nontrivial difference in lignin composition. In their study, the total lignin percentage of the untreated OPEFB was $25.6 \%$, whereas the total lignin percentage of the untreated OPMF was $31.3 \%$. The pretreatment method employed was SHS with laccase pretreatment. To obtain similar delignification percentages in each, the number of laccase units per substrate was increased by a factor of 4 for the OPMF, and the SHS temperature was $10^{\circ} \mathrm{C}$ greater, compared to the OPEFB pretreatment conditions. This study clearly illustrates that the pretreatment conditions should be more severe when the amount of lignin is greater in the oil palm biomass of interest. 
Table 8. Particular Pretreatment Methods Performed on Different Types of Oil Palm Biomass

\begin{tabular}{|c|c|c|c|c|c|c|}
\hline $\begin{array}{l}\text { Pretreatment } \\
\text { Method }\end{array}$ & $\begin{array}{l}\text { Major } \\
\text { Agents } \\
\text { Used }\end{array}$ & Conditions & $\begin{array}{l}\text { Oil Palm } \\
\text { Biomass }\end{array}$ & $\begin{array}{l}\text { Concluding } \\
\text { Remarks }\end{array}$ & $\begin{array}{l}\text { Potential } \\
\text { Application }\end{array}$ & References \\
\hline \multirow{3}{*}{$\begin{array}{l}\text { Sequential } \\
\text { SHS } \\
\text { explosion } \\
\text { and alkaline } \\
\text { autoclaving } \\
\text { pretreatment }\end{array}$} & $\begin{array}{c}\mathrm{SHS} \\
15 \% \\
\mathrm{NaOH}\end{array}$ & $\begin{array}{c}180^{\circ} \mathrm{C}, 0.6 \\
\mathrm{MPa}, 5 \mathrm{~min} ; \\
\text { autoclave, } \\
40 \mathrm{~min}\end{array}$ & OPEFB & $\begin{array}{l}11.7 \text { wt\% } \\
\text { remaining } \\
\text { lignin }\end{array}$ & \multirow{3}{*}{$\begin{array}{l}\text { Production of } \\
\text { xylose }\end{array}$} & \multirow{3}{*}{$\begin{array}{c}\text { Thamsee } \\
\text { et al. } \\
\text { (2018) }\end{array}$} \\
\hline & $\begin{array}{c}\mathrm{SHS}, 5 \% \\
\mathrm{NaOH}\end{array}$ & $\begin{array}{c}180^{\circ} \mathrm{C}, 0.6 \\
\mathrm{MPa}, 5 \mathrm{~min} ; \\
\text { autoclave, } \\
30 \mathrm{~min}\end{array}$ & OPF & $\begin{array}{l}9.83 \text { wt } \% \\
\text { remaining } \\
\text { lignin }\end{array}$ & & \\
\hline & $\begin{array}{c}\mathrm{SHS}, 2 \% \\
\mathrm{NaOH}\end{array}$ & $\begin{array}{l}180^{\circ} \mathrm{C}, 0.6 \\
\mathrm{MPa}, 5 \mathrm{~min} ; \\
\text { autoclave, } \\
30 \mathrm{~min}\end{array}$ & OPT & $\begin{array}{l}10.99 \text { wt\% } \\
\text { remaining } \\
\text { lignin }\end{array}$ & & \\
\hline \multirow{2}{*}{ Irradiation } & \multirow{2}{*}{ Microwave } & \multirow{2}{*}{$\begin{array}{c}2450 \mathrm{MHz} \\
450 \mathrm{~W}, 5 \mathrm{~min}\end{array}$} & OPEFB & $\begin{array}{c}29.1 \% \\
\text { crystallinity of } \\
\alpha-\text {-cellulose of } \\
\text { OPEFB }\end{array}$ & \multirow{2}{*}{$\begin{array}{c}\text { Raw } \\
\text { material for } \\
\text { cellulose } \\
\text { nanocrystals }\end{array}$} & \multirow{2}{*}{$\begin{array}{l}\text { Kasim et } \\
\text { al. }(2018)\end{array}$} \\
\hline & & & OPMF & $\begin{array}{c}23.8 \% \\
\text { crystallinity of } \\
\alpha \text {-cellulose of } \\
\text { OPMF }\end{array}$ & & \\
\hline \multirow{4}{*}{$\begin{array}{l}\text { SHS with } \\
\text { laccase } \\
\text { pretreatment }\end{array}$} & $\begin{array}{l}0.05 \mathrm{M} \\
\text { sodium } \\
\text { acetate } \\
\text { buffer, }\end{array}$ & $\begin{array}{c}\text { SHS; } 6.6 \\
\mathrm{~kW}, 4.95 \\
\mathrm{~kg} / \mathrm{h}, 180^{\circ} \mathrm{C}, \\
60 \mathrm{~min} \\
\end{array}$ & OPEFB & $38.7 \%$ removal & \multirow{4}{*}{$\begin{array}{l}\text { Production of } \\
\text { fermentable } \\
\text { sugars }\end{array}$} & \multirow{4}{*}{$\begin{array}{l}\text { Rizal et al. } \\
\text { (2018b) }\end{array}$} \\
\hline & $\begin{array}{c}100 \mathrm{U} / \mathrm{g} \\
\text { substrate } \\
\text { of laccase }\end{array}$ & $\begin{array}{c}\text { Laccase: } \mathrm{pH} \\
4.8,150 \mathrm{rpm} \text {, } \\
50^{\circ} \mathrm{C}, 24 \mathrm{~h}\end{array}$ & & & & \\
\hline & $\begin{array}{l}0.05 \mathrm{M} \\
\text { sodium } \\
\text { acetate } \\
\text { buffer, }\end{array}$ & $\begin{array}{c}\text { SHS: } 6.6 \\
\text { kW, } 4.95 \\
\mathrm{~kg} / \mathrm{h}, 190^{\circ} \mathrm{C}, \\
60 \mathrm{~min}\end{array}$ & \multirow[t]{2}{*}{ OPMF } & \multirow{2}{*}{$\begin{array}{c}39.6 \% \text { removal } \\
\text { of lignin }\end{array}$} & & \\
\hline & $\begin{array}{c}400 \mathrm{U} / \mathrm{g} \\
\text { substrate } \\
\text { of laccase }\end{array}$ & $\begin{array}{l}\text { Laccase: } \mathrm{pH} \\
4.8,150 \mathrm{rpm} \text {, } \\
50^{\circ} \mathrm{C}, 24 \mathrm{~h}\end{array}$ & & & & \\
\hline
\end{tabular}

Kasim et al. (2018), seeking raw materials for nanocrystalline cellulose, produced $\alpha$-cellulose from OPEFB with a greater degree of crystallinity (29.1\%) compared to that of OPMF $(23.8 \%)$. Cellulose with a greater degree of crystallinity is preferred for producing raw materials for nanocrystalline cellulose. Therefore, a researcher interested in producing good-quality nanocrystalline cellulose should use OPEFB, rather than OPMF. Thus, the type of oil palm biomass should be selected based on the requirements of the final product. Harahap and Kresnowati (2018) tested three pretreatment methods on OPEFB to determine the most efficient method for recovering xylose. They found that autohydrolysis gave the best xylose recovery from hemicellulose, compared to acid pretreatment and alkaline pretreatment. Therefore, not only lignin content but also cellulose and hemicellulose contents should be considered, depending on the desired final product, and the pretreatment method should be chosen to produce the maximum yield of the intended product. 


\section{CHEMICAL DETOXIFICATION METHODS FOR OIL PALM BIOMASS}

The presence of inhibitory by-products of fermentation would not only hinder the overall fermentation process, but also induce environmental stress for the fermentative organism due to the deficiency of water content created by fermentation inhibitors. Thus, detoxification is needed to enhance the fermentation yield, by means of elimination or converting the inhibitory products into inactive compounds (Kunasundari et al. 2017). One of the disadvantages of pretreatment is the production of toxic materials, such as HMF and furfural. These degrade the sugar produced and interfere in the microbial fermentation process, thereby decreasing the production of ethanol. Therefore, additional steps are required to detoxify the inhibitors produced, and different types of detoxification can be employed (Table 9). Physical detoxification methods such as filtration, including vacuum filtration and even nanofiltration, are expensive. The cheapest detoxification method, washing with water, is labor-intensive, and the effluent is environmentally toxic. There are also chemical detoxification methods, such as overliming, ion exchange, and activated carbon treatment. Microorganisms can also be used to detoxify the inhibitors produced. The toxins are produced due to the high amount of lignin present in plant materials; therefore, the latest method employed is to modify the plants genetically. Because this review article specifically focuses on pretreatment of oil palm biomass, only the detoxification methods related to oil palm biomass are discussed. Activated charcoal detoxification has been extensively applied to eliminate inhibitory compounds from pretreated oil palm biomass solutions owing to its high adsorption capacity, good chemical stability, low toxicity, and low-cost. Moreover, physical form and the composition of activated carbon directly affects its adsorbent properties, which directly affects the detoxification (Kunasundari et al. 2017).

According to Brito et al. (2018), overliming is able to reduce furfural, HMF, and phenolic compounds slightly, while simultaneously decreasing the reducing sugar yield. For detoxification by overliming, hemicellulosic hydrolysate obtained from OPMF was treated with $\mathrm{Ca}(\mathrm{OH})_{2}$ to reach a $\mathrm{pH}$ of 10 and the suspension was placed in a water bath at $60{ }^{\circ} \mathrm{C}$ with periodic stirring for 30 min. Finally, $\mathrm{pH}$ was neutralized by adding $\mathrm{H}_{2} \mathrm{SO}_{4}$. Detoxification by activated charcoal was achieved with the addition of $5 \%(\mathrm{w} / \mathrm{v})$ activated charcoal to the OPMF hydrolysate, where the mixture was vigorously stirred at $50{ }^{\circ} \mathrm{C}$ on a magnetic stirrer for $30 \mathrm{~min}$. It was revealed that activated carbon treatment has been able to increase the reducing sugar yield and considerably decrease furfural and HMF. According to their study, hydrolysate detoxified with activated charcoal attained the highest reducing sugar yield of $94.9 \pm 0.64 \mathrm{~g} / \mathrm{L}$, compared to reducing sugar concentrations obtained with the detoxification by overliming $(60.74 \pm 4.0 \mathrm{~g} / \mathrm{L})$ and combined overliming and activated charcoal treatment $(62.38 \pm 3.47 \mathrm{~g} / \mathrm{L})$. Al-Tabib et al. (2018) observed a similar pattern when employing activated carbon treatment, which also has been able to increase butanol and ethanol yields. Kunasundari et al. (2017) employed activated charcoal of different physical forms (powder, pellet, granular) to detoxify sap of OPT. Activated charcoal in the form of powder (treated with $\mathrm{HCl}$ ) was able to decrease the total phenolic compounds up to c.a. $92 \%$, although activated charcoal in granular and pellet forms were not successful in reducing total phenolic compounds (1.4-17\%). The researchers found that the loss of total sugars upon activated charcoal detoxification was not significant. 
Table 9. Different Detoxification Methods Used for Oil Palm Biomass, Conditions Used, and Amounts of Toxins Removed

\begin{tabular}{|c|c|c|c|c|c|c|c|c|}
\hline $\begin{array}{l}\text { Detoxification } \\
\text { Treatment }\end{array}$ & $\begin{array}{l}\text { Chemicals } \\
\text { Used }\end{array}$ & Conditions & $\begin{array}{l}\text { Oil Palm } \\
\text { Biomass }\end{array}$ & \begin{tabular}{|c|}
$\mathrm{HMF}$ \\
$(\mathrm{mg} / \mathrm{L})$
\end{tabular} & $\begin{array}{r}\text { Furfura } \\
\text { (mg/L) }\end{array}$ & \begin{tabular}{|c} 
Total \\
Phenolic \\
Compounds \\
$(\mathrm{g} / \mathrm{L})$ \\
\end{tabular} & \begin{tabular}{|c|} 
Final \\
Ethanol \\
(g/L)
\end{tabular} & Reference \\
\hline Overliming & $\begin{array}{c}\mathrm{Ca}(\mathrm{OH})_{2} \\
\mathrm{H}_{2} \mathrm{SO}_{4}\end{array}$ & $\begin{array}{l}\mathrm{pH} 10, \\
60^{\circ} \mathrm{C}, \\
30 \mathrm{~min}\end{array}$ & \multirow{3}{*}{ OPMF } & $\begin{array}{c}46.1 \text { to } \\
28.2\end{array}$ & $\begin{array}{c}490 \text { to } \\
246\end{array}$ & $\begin{array}{c}0.66 \text { to } \\
0.44\end{array}$ & $\begin{array}{c}6.13 \\
\pm \\
0.30\end{array}$ & \multirow{3}{*}{$\begin{array}{c}\text { Brito et al. } \\
\quad(2018)\end{array}$} \\
\hline $\begin{array}{l}\text { Activated } \\
\text { charcoal }\end{array}$ & $\begin{array}{c}5 \mathrm{wt} \% \\
\text { activated } \\
\text { charcoal }\end{array}$ & $\begin{array}{l}\text { Vigorous } \\
\text { stirring for } \\
30 \mathrm{~min}, \\
50^{\circ} \mathrm{C}\end{array}$ & & $\begin{array}{l}46.14 \\
\text { to ND } \\
\text { level }\end{array}$ & $\begin{array}{c}490 \text { to } \\
3.37\end{array}$ & $\begin{array}{c}0.66 \text { to } \\
0.058\end{array}$ & $\begin{array}{c}5.20 \\
\pm \\
0.15\end{array}$ & \\
\hline $\begin{array}{c}\text { Combining } \\
\text { overliming } \\
\text { with activateo } \\
\text { charcoal }\end{array}$ & $\begin{array}{c}\text { Combination } \\
\text { of above }\end{array}$ & $\begin{array}{c}\text { Combination } \\
\text { of above }\end{array}$ & & $\begin{array}{c}46.1 \text { to } \\
\text { ND } \\
\text { level }\end{array}$ & $\begin{array}{c}489.5 \\
\text { to } 2.84\end{array}$ & $\begin{array}{c}0.66 \text { to } \\
0.026\end{array}$ & & \\
\hline $\begin{array}{c}\text { Powdered } \\
\text { activated } \\
\text { charcoal } \\
\text { (treated with } \\
\mathrm{HCl} \text { ) }\end{array}$ & $\begin{array}{r}2.5 \mathrm{wt} \% \\
\text { activated } \\
\text { charcoal }\end{array}$ & $\begin{array}{c}\text { Incubated } \\
\text { at } 4{ }^{\circ} \mathrm{C} \text { for } \\
5 \mathrm{~h}\end{array}$ & $\begin{array}{l}\text { Sap of } \\
\text { OPT }\end{array}$ & - & - & $\begin{array}{l}0.76 \text { to } \\
0.06\end{array}$ & - & $\begin{array}{l}\text { Kunasundari } \\
\text { et al. (2017) }\end{array}$ \\
\hline Overliming & $\begin{array}{c}\mathrm{Ca}(\mathrm{OH})_{2} \\
1 \mathrm{~g} / \mathrm{L} \\
\mathrm{Na}_{2} \mathrm{SO}_{3}, \mathrm{HCl}\end{array}$ & $\begin{array}{c}\mathrm{pH} \mathrm{10,} \\
80^{\circ} \mathrm{C}, 1 \mathrm{~h}\end{array}$ & & \begin{tabular}{|c|}
100.0 \\
to 80.0
\end{tabular} & $\begin{array}{c}\text { No } \\
\text { change }\end{array}$ & - & $\begin{array}{c}0.19 \\
\pm \\
0.01\end{array}$ & \multirow{2}{*}{$\begin{array}{c}\text { Al-Tabib } \\
\text { et al. } \\
\text { (2018) }\end{array}$} \\
\hline $\begin{array}{l}\text { Activated } \\
\text { charcoal }\end{array}$ & - & $\begin{array}{l}200 \mathrm{rpm}, \\
30^{\circ} \mathrm{C}, 1 \mathrm{~h}\end{array}$ & $\begin{array}{l}\text { Palm } \\
\text { kernel } \\
\text { cake }\end{array}$ & $\begin{array}{l}100.0 \\
\text { to } 2.0\end{array}$ & $\begin{array}{l}20.0 \\
\text { to } \\
10.0\end{array}$ & - & $\begin{array}{l}0.25 \\
\pm \\
0.01\end{array}$ & \\
\hline
\end{tabular}

Note: ND, Not Detectable

\section{FUTURE RECOMMENDATIONS}

There are few research studies on pretreatment methods performed specifically on oil palm biomass. The chemical composition differs based on the type of oil palm biomass. Various pretreatment strategies have been employed in view of modifying the recalcitrant structure of oil palm biomass to promote its digestibility for anaerobic digestion. Maximizing the surface area of the biomass is a vital strategy, which allows more microbes or enzymes to interact with the biomass surface in promoting cellulose degradation. Although many studies have been performed on various pretreatment methods, deducing theories for the most suitable pretreatment method for oil palm biomass is not possible. 
Utilization of a proper pretreatment method primarily depends on the type of oil palm biomass residue, economic viability, and successive processes involved after pretreatment. Although an efficient pretreatment technique enhances the biogas yield in the process of an anaerobic co-digestion, the advancement of a sustainable and an economically viable pretreatment tactic is important for oil palm biomass. However, the present review article has been able to compare and contrast some notable features with the available data. Considering these limitations, the authors have a few recommendations for researchers interested in studying oil palm biomass. Oil palm biomass is a readily available yet underutilized feedstock. Most studies have focused on OPEFB, and there is very limited data on other oil palm biomass residues, such as OPMF, OPL, OPT, and oil palm mill effluents. Therefore, future research studies should focus more on utilizing other types of oil palm biomass to produce value-added products.

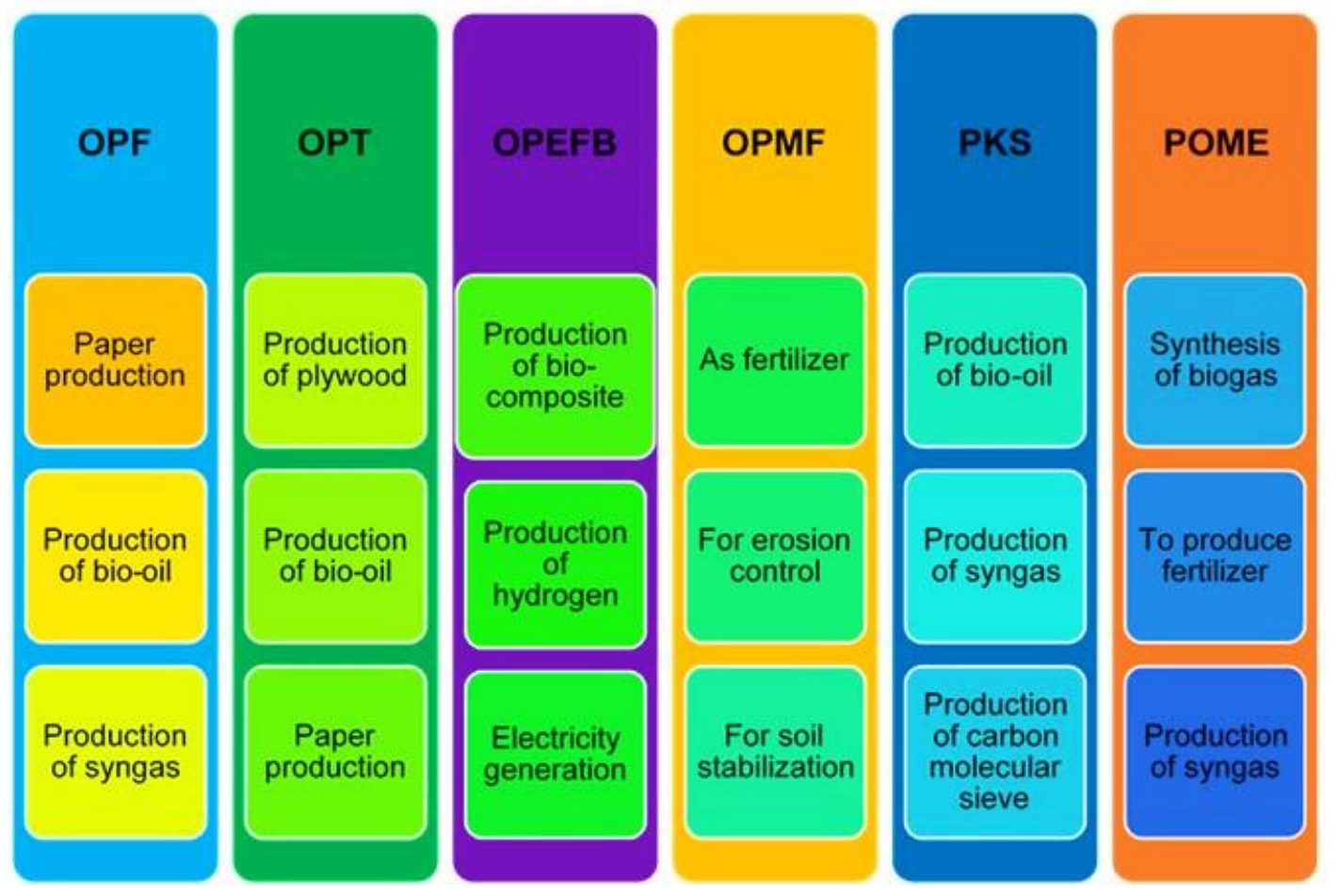

Fig. 7. Various industrial applications of oil palm biomass residues (Onoja et al. 2019)

The next important observation is that most research studies have been based on one pretreatment method. However, there could be other pretreatment methods or a combination of pretreatment methods that could be optimized to produce a greater yield of the desired product. Therefore, research should aim to examine multiple possible pretreatment methods and combinations of different pretreatment methods to obtain greater yields. Additionally, the same pretreatment method should be tested on different types of oil palm biomass, as the chemical composition differs depending on the biomass residue. Consequently, there could be a more suitable type of oil palm biomass, which produces value-added products with more desirable features, than the ones that the researchers focused on in their studies.

Onoja et al. (2019) summarized numerous commercially valuable end products attained directly or indirectly from oil palm biomass as depicted in Fig. 7. Utilization of 
available technologies to valorize oil palm biomass would reduce the amount of oil palm biomass wastes generated. Onoja et al. (2019) in their review paper pointed out that OPT, OPF and OPEFB can be utilized as bio-fertilizer (composting). Figure 8 points out few waste management strategies of oil palm biomass adopted during oil palm replanting and in palm oil processing mills. Moreover, the production of biogas from biodegradable wastes such oil palm biomass residues promotes waste management practices in many countries.

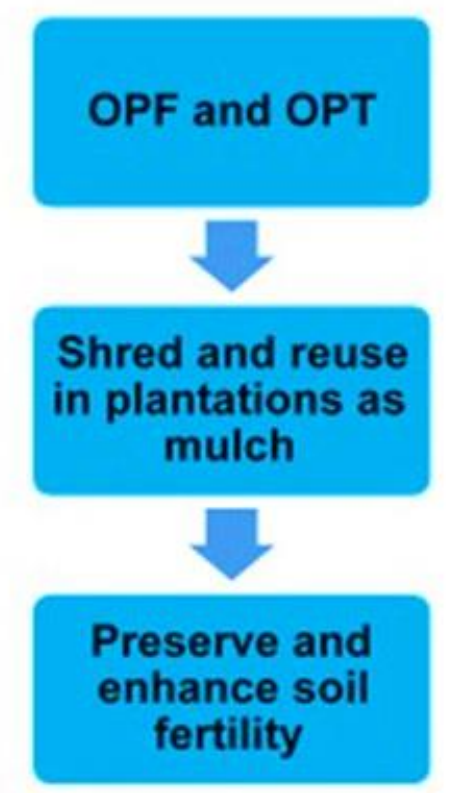

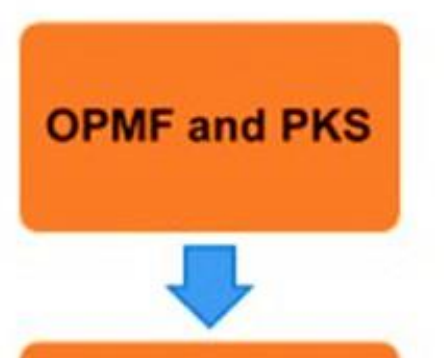

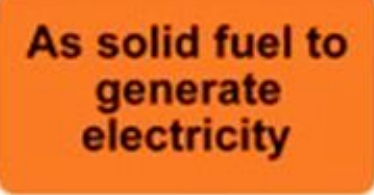

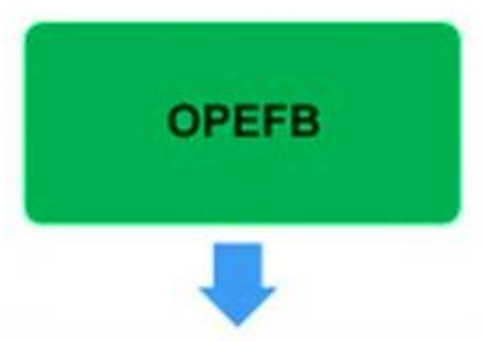

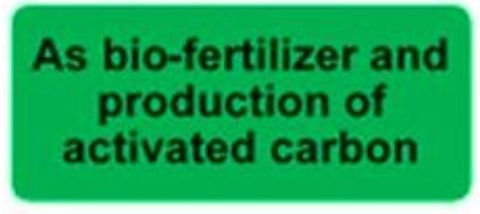

Fig. 8. Waste management strategies of oil palm biomass during oil palm replanting and in palm oil processing mills

Finally, very few studies have upgraded their work to suit industry. The conditions used for a pilot plant are not always suitable for industrial-scale applications. For example, eco-friendly pretreatment methods such as microwave pretreatment can be very costly if expanded to an industrial-scale plant. Therefore, cost-effectiveness, profitability, material utilization, production quality, speed, energy efficiency, and labor efficiency should be considered. Future studies should focus on expanding their pilot plants to suit industry and increase profitability.

\section{CONCLUSIONS}

1. The present review article has summarized various pretreatment methods performed on oil palm biomass and detoxification methods employed to eliminate toxic products resulting from pretreatment.

2. Utilizing a pretreatment step in anaerobic digestion process enhances the digestibility of oil palm biomass and lignin removal by degrading its complex structure in order to improve biogas yields.

3. Of all the studied types of oil palm biomass, the most popular is oil palm empty fruit bunch (OPEFB), which has a comparatively low lignin content (14.2\% to 38.4\%). Its 
popularity could be due to the ease of performing pretreatment, due to the relatively low lignin content. The greatest amount of cellulose is present in oil palm trunk (OPT) (38.8\% to $46.9 \%)$, so a researcher seeking a high reducing sugar yield would prefer to study OPT.

4. As the current trend is towards environmentally friendly pretreatment methods, more researchers are now focused on methods such as ultrasonication pretreatment, supercritical $\mathrm{CO}_{2}$ explosion, and enzymatic pretreatment. Furthermore, most pretreatment methods are combined with another. For instance, enzymatic pretreatment methods have been combined with physical pretreatment methods to maximize yield.

5. Studies of different pretreatment methods with a particular type of oil palm biomass have shown that combining chemical pretreatments with increased physical conditions, such as high pressure and temperature, leads to better delignification

6. Researchers are currently giving increased attention to detoxification methods, which can eliminate the toxic products produced during pretreatment and can concurrently increase the yield. Overliming and activated charcoal treatment are the two most widely used methods in oil palm pretreatment.

\section{ACKNOWLEDGMENTS}

This work was supported by Universiti Sains Malaysia Research University Incentive (RUI) Grant No. (1001/PKIMIA/8011077) and external grant (304/PKIMIA/6501094/L129). Rushan Diyanilla profoundly wishes to acknowledge Universiti Sains Malaysia for providing the USM Graduate Assistant Scheme. The authors thank to the Ministry for Research Technology and Higher Education Republic of Indonesia for providing research grant with contract number 42/P/RPL-LIPI/INSINAS1/III/2020 through the Programme of National Innovation System Research Incentive (INSINAS) FY 2020.

\section{REFERENCES CITED}

Ab Rahim, A. H., Man, Z., Sarwono, A., Hamzah, W. S. W., Yunus, N. M., and Wilfred, C. D. (2018). "Extraction and comparative analysis of lignin extract from alkali and ionic liquid pretreatment," in: Journal of Physics: Conference Series 1123, Kuala Lumpur, Malaysia. DOI: 10.1088/1742-6596/1123/1/012052

Abdul, P. M., Jahim, J. M., Harun, S., Markom, M., Lutpi, N. A., Hassan, O., Balan, V., Dale, B. E., and Nor, M. T. M. (2016). "Effects of changes in chemical and structural characteristic of ammonia fibre expansion (AFEX) pretreated oil palm empty fruit bunch fibre on enzymatic saccharification and fermentability for biohydrogen," Bioresource Technology 211, 200-208. DOI: 10.1016/j.biortech.2016.02.135

Abraham, A., Mathew, A. K., Park, H., Choi, O., Sindhu, R., Parameswaran, B., Pandey, A., Park, J. H., and Sang, B.-I. (2020). "Pretreatment strategies for enhanced biogas production from lignocellulosic biomass," Bioresource Technology 301, 122725. DOI: $10.1016 /$ j.biortech.2019.122725

Abu Darim, R., Azizan, A., and Salihon, J. (2018). "Study of crystallinity index (CrI) of oil palm frond pretreatment using aqueous [EMIM][OAc] in a closed system," in: 
IOP Conference Series: Materials Science and Engineering 358, Putrajaya, Malaysia. DOI: 10.1088/1757-899X/358/1/012007

Ahmad, F., Silva, E. L., and Varesche, M. B. A. (2018a). "Hydrothermal processing of biomass for anaerobic digestion - A review," Renewable and Sustainable Energy Reviews 98, 108-124. DOI: 10.1016/j.rser.2018.09.008

Ahmad, N., Zakaria, M. R., Yusoff, M. Z. M., Fujimoto, S., Inoue, H., Ariffin, H., Hassan, M. A., and Shirai, Y. (2018b). "Subcritical water-carbon dioxide pretreatment of oil palm mesocarp fiber for xylooligosaccharide and glucose production," Molecules 23(6). DOI: 10.3390/molecules23061310

Ahmad, S., Pathak, V. V., Kothari, R., and Singh, R. P. (2018c). "Prospects for pretreatment methods of lignocellulosic waste biomass for biogas enhancement: Opportunities and challenges," Biofuels 9(5), 575-594. DOI: 10.1080/17597269.2017.1378991

Ahmad Sobri, N. S., Harun, S., Ishak, N. S., Md Jahim, J., and Wahab Mohammad, A. (2019). "Enhancement of high xylan recovery from black liquor of alkaline pretreated oil palm frond and its physicochemical properties," BioResources 14(3), 5400-5421. DOI: $10.15376 /$ biores. 14.3.5400-5421

Ahring, B. K., Biswas, R., Ahamed, A., Teller, P. J., and Uellendahl, H. (2015). "Making lignin accessible for anaerobic digestion by wet-explosion pretreatment," Bioresource Technology 175, 182-188. DOI: 10.1016/j.biortech.2014.10.082

Al-Tabib, A.I., Al-Shorgani, N. K. N., Hasan, H. A., Hamid, A. A., and Kalil, M. S. (2018). "Assessment of the detoxification of palm kernel cake hydrolysate for butanol production by Clostridium acetobutylicum YM1," Biocatalysis and Agricultural Biotechnology 13, 105-109. DOI: 10.1016/j.bcab.2017.11.015

Ali, N., Zhang, Q., Liu, Z.-Y., Li, F.-L., Lu, M., and Fang, X.-C. (2020). "Emerging technologies for the pretreatment of lignocellulosic materials for bio-based products," Applied Microbiology and Biotechnology 104, 455-473. DOI: 10.1007/s00253-01910158-w

Amani, A. H. F., Toh, S. M., Tan, J. S., and Lee, C. K. (2018). "The efficiency of using oil palm frond hydrolysate from enzymatic hydrolysis in bioethanol production," Waste and Biomass Valorization 9, 539-548. DOI: 10.1007/s12649-017-0005-z

Anita, S. H., Fitria, Solihat, N. N., Sari, F. P., Risanto, L., Fatriasari, W., and Hermiati, E. (2020). "Optimization of microwave-assisted oxalic acid pretreatment of oil palm empty fruit bunch for production of fermentable sugars," Waste and Biomass Valorization 11, 2673-2687. DOI: 10.1007/s12649-018-00566-w

Arbaain, E. N. N., Bahrin, E. K., Ibrahim, M. F., Ando, Y., and Abd-Aziz, S. (2019). "Biological pretreatment of oil palm empty fruit bunch by Schizophyllum commune ENN1 without washing and nutrient addition," Processes 7(7). DOI: 10.3390/pr7070402

Ariffin, H., Norrrahim, M. N. F., Yasim-Anuar, T. A. T., Nishida, H., Hassan, M. A., Ibrahim, N. A., and Yunus, W. M. Z. W. (2018). "Oil palm biomass cellulosefabricated polylactic acid composites for packaging applications," in:

Bionanocomposites for Packaging Applications, M. Jawaid and S. K. Swain (eds.), Springer, Cham, Switzerland, pp. 95-105. DOI: 10.1007/978-3-319-67319-6_5

Arora, R., Sharma, N. K., Kumar, S., and Sani, R. K. (2019). "Chapter 9 Lignocellulosic ethanol: Feedstocks and bioprocessing," in: Bioethanol Production from Food Crops: Sustainable Sources, Interventions, and Challenges, R. C. Ray and 
S. Ramachandran (eds.), Academic Press, London, UK, pp. 165-185. DOI: 10.1016/B978-0-12-813766-6.00009-6

Az-Zahraa, B., Zakaria, S., Daud, M. F. B., and Jaafar, S. N. S. (2018). "Removal of oil palm trunk lignin in ammonium hydroxide pretreatment," AIP Conference Proceedings 1940. DOI: 10.1063/1.5027932

Azizan, A., Mokti, N., Zaharudin, S., and Safaai, N. S. M. (2019). “Concerns on analytical results involving infrared to microscopic data dealing with ionic liquids in pretreatment of lignocellulosic biomass," Key Engineering Materials 797, 211-217. DOI: 10.4028/www.scientific.net/kem.797.211

Azmi, I. S., Azizan, A., and Salleh, R. M. (2018). "Pretreatment of oil palm frond (OPF) with ionic liquid," in: IOP Conference Series: Materials Science and Engineering 358, Putrajaya, Malaysia. DOI: 10.1088/1757-899X/358/1/012071

Baruah, J., Nath, B. K., Sharma, R., Kumar, S., Deka, R. C., Baruah, D. C., and Kalita, E. (2018). "Recent trends in the pretreatment of lignocellulosic biomass for value-added products," Frontiers in Energy Research 6. DOI: 10.3389/fenrg.2018.00141

Benazzi, T., Calgaroto, S., Dalla Rosa, C., Vladimir Oliveira, J., and Mazutti, M. A. (2013). "Hydrolysis of sugarcane bagasse using supercritical carbon dioxide to obtain fermentable sugars," Journal of Chemical Technology \& Biotechnology 88(9), 17661768. DOI: $10.1002 /$ jctb.4002

Bichot, A., Lerosty, M., Geirnaert, L., Méchin, V., Carrère, H., Bernet, N., Delgenès, J.P., and García-Bernet, D. (2019). "Soft microwave pretreatment to extract phydroxycinnamic acids from grass stalks," Molecules 24(21). DOI: 10.3390/molecules24213885

Bichot, A., Lerosty, M., Radoiu, M., Méchin, V., Bernet, N., Delgenès, J.-P., and GarcíaBernet, D. (2020). "Decoupling thermal and non-thermal effects of the microwaves for lignocellulosic biomass pretreatment," Energy Conversion and Management 203. DOI: 10.1016/j.enconman.2019.112220

Boon, J. G., Hashim, R., Danish, M., and Nadhari, W. N. A. W. (2019). "Physical and mechanical properties of binderless particleboard made from steam-pretreated oil palm trunk particles," Journal of Composites Science 3(2), 46. DOI: $10.3390 / \mathrm{jcs} 3020046$

Brito, P. L., de Azevedo Ferreira, C. M., Silva, A. F. F., de Araújo Pantoja, L., Nelson, D. L., and dos Santos, A. S. (2018). "Hydrolysis, detoxification and alcoholic fermentation of hemicellulose fraction from palm press fiber," Waste and Biomass Valorization 9(6), 957-968. DOI: 10.1007/s12649-017-9882-4

Budiman, P. M., and Wu, T. Y. (2016). "Ultrasonication pre-treatment of combined effluents from palm oil, pulp and paper mills for improving photofermentative biohydrogen production," Energy Conversion and Management 119, 142-150. DOI: 10.1016/j.enconman.2016.03.060

Cardona, E., Llano, B., Peñuela, M., Peña, J., and Rios, L. A. (2018). "Liquid-hot-water pretreatment of palm-oil residues for ethanol production: An economic approach to the selection of the processing conditions," Energy 160, 441-451. DOI: 10.1016/j.energy.2018.07.045

Chan, C. M., Chin, S. X., Chook, S. W., Chia, C. H., and Zakaria, S. (2018). "Combined mechanical-chemical pre-treatment of oil palm empty fruit bunch (EFB) fibers for adsorption of methylene blue (MB) in aqueous solution," Malaysian Journal of Analytical Sciences 22(6), 1007-1013. DOI: 10.17576/mjas-2018-2206-10 
Chang, S. H. (2018). "Bio-oil derived from palm empty fruit bunches: Fast pyrolysis, liquefaction and future prospects," Biomass and Bioenergy 119, 263-276. DOI: 10.1016/j.biombioe.2018.09.033

Charnnok, B., Sakdaronnarong, C., and Sinbuathong, N. (2019). "Hydrothermal pretreatment with sulfonated bentonite catalyst enhances potassium removal and bioconversion of oil palm empty fruit bunch to sugar and biohydrogen," Biomass Conversion and Biorefinery 9(2), 389-399. DOI: 10.1007/s 13399-018-0360-4

Chavalparit, O., Sasananan, S., Kullavanijaya, P., and Charoenwuttichai, C. (2018). "Anaerobic co-digestion of hydrolysate from alkali pre-treated oil palm empty fruit bunches with biodiesel waste glycerol," Journal of Material Cycles and Waste Management 20(1), 336-344. DOI: 10.1007/s10163-017-0585-5

Cheah, W. Y., Show, P. L., Juan, J. C., Chang, J.-S., and Ling, T. C. (2018). "Waste to energy: The effects of Pseudomonas sp. on Chlorella sorokiniana biomass and lipid productions in palm oil mill effluent," Clean Technologies and Environmental Policy 20(9), 2037-2045. DOI: 10.1007/s10098-018-1505-7

Cherukuri, P. J., and Akkina, R. C. (2019). "Bioconversion of biomass to biofuel using fungal consortium," in: Recent Advancement in White Biotechnology Through Fungi - Volume 3: Perspective for Sustainable Environments, A. N. Yadav, S. Singh, S. Mishra, and A. Gupta (eds.), Springer, Cham, Switzerland, pp. 381-396. DOI: 10.1007/978-3-030-25506-0_15

Chin, D. W.-K., Lim, S., Pang, Y.-L., Leong, L.-K., and Lim, C.-H. (2019). "Investigation of organosolv pretreatment to natural microbial-degraded empty fruit bunch for sugar based substrate recovery," Energy Procedia 158, 1065-1071. DOI: 10.1016/j.egypro.2019.01.258

Choopakar, O., Polprasert, C., Elefsiniotis, P., and Polprasert, S. (2018). "The effect of steam and glycerol pretreatment on chemical contents of oil palm empty fruit bunch (EFB)," Applied Environmental Research 40(2), 61-67. DOI:

10.35762/AER.2018.40.2.6

de Menezes Nogueira, I., Avelino, F., de Oliveira, D. R., Souza, N. F., Rosa, M. F., Mazzetto, S. E., and Lomonaco, D. (2019). "Organic solvent fractionation of acetosolv palm oil lignin: The role of its structure on the antioxidant activity," International Journal of Biological Macromolecules 122, 1163-1172. DOI: 10.1016/j.ijbiomac.2018.09.066

Debiagi, F., Madeira, T. B., Nixdorf, S. L., and Mali, S. (2020). "Pretreatment efficiency using autoclave high-pressure steam and ultrasonication in sugar production from liquid hydrolysates and access to the residual solid fractions of wheat bran and oat hulls," Applied Biochemistry and Biotechnology 190, 166-181. DOI: 10.1007/s12010019-03092-0

Ding, C., Wang, X., and Li, M. (2019). "Evaluation of six white-rot fungal pretreatments on corn stover for the production of cellulolytic and ligninolytic enzymes, reducing sugars, and ethanol," Applied Microbiology and Biotechnology 103(14), 5641-5652. DOI: 10.1007/s00253-019-09884-y

Elgharbawy, A. A., Alam, M. Z., Moniruzzaman, M., and Goto, M. (2016). "Ionic liquid pretreatment as emerging approaches for enhanced enzymatic hydrolysis of lignocellulosic biomass," Biochemical Engineering Journal 109, 252-267. DOI: 10.1016/j.bej.2016.01.021

Elgharbawy, A. A., Alam, M. Z., Moniruzzaman, M., Kabbashi, N. A., and Jamal, P. (2018). "Chemical and structural changes of pretreated empty fruit bunch (EFB) in 
ionic liquid-cellulase compatible system for fermentability to bioethanol," 3 Biotech 8(5). DOI: 10.1007/s13205-018-1253-8

Eom, I.-Y., Yu, J.-H., Jung, C.-D., and Hong, K.-S. (2015). "Efficient ethanol production from dried oil palm trunk treated by hydrothermolysis and subsequent enzymatic hydrolysis," Biotechnology for Biofuels, 8(1), 83. DOI:10.1186/s13068-015-0263-6

Espinosa, C., Arrieta, B., Gonzalez-Delgado, A. D., Ojeda, K., and Sanchez, E. (2018). "Technical and environmental evaluation of an integrated biorefinery from residual biomass of oil palm fruit to obtain biobutanol and biohydrogen," Journal of Engineering and Applied Sciences 13(2), 533-540. DOI: 10.36478/jeasci.2018.533.540

Fatriasari, W., Anita, S. H., and Risanto, L. (2017). "Microwave assisted acid pretreatment of oil palm empty fruit bunches (EFB) to enhance its fermentable sugar production," Waste and Biomass Valorization 8(2), 379-391. DOI: 10.1007/s12649016-9573-6

Fatriasari, W., Raniya, R., Oktaviani, M., and Hermiati, E. (2018). "The improvement of sugar and bioethanol production of oil palm empty fruit bunches (Elaeis guineensis Jacq) through microwave-assisted maleic acid pretreatment," BioResources 13(2), 4378-4403. DOI: 10.15376/biores.13.2.4378-4403

Financie, R., Moniruzzaman, M., and Uemura, Y. (2016). "Enhanced enzymatic delignification of oil palm biomass with ionic liquid pretreatment," Biochemical Engineering Journal 110, 1-7. DOI:10.1016/j.bej.2016.02.008

Gatt, E., Rigal, L., and Vandenbossche, V. (2018). "Biomass pretreatment with reactive extrusion using enzymes: A review," Industrial Crops and Products 122, 329-339. DOI: $10.1016 /$ j.indcrop.2018.05.069

Ghazali, N. F., and Makhtar, N. A. (2018). "Enzymatic hydrolysis of oil palm empty fruit bunch and its kinetics," Malaysian Journal of Analytical Sciences 22(4), 715-722. DOI: 10.17576/mjas-2018-2204-18

Gonzales, R. R., Kim, J. S., and Kim, S.-H. (2019). “Optimization of dilute acid and enzymatic hydrolysis for dark fermentative hydrogen production from the empty fruit bunch of oil palm," International Journal of Hydrogen Energy 44(4), 2191-2202. DOI: 10.1016/j.ijhydene.2018.08.022

Hamzah, N., Tokimatsu, K., and Yoshikawa, K. (2019). "Solid fuel from oil palm biomass residues and municipal solid waste by hydrothermal treatment for electrical power generation in Malaysia: A review," Sustainability 11(4), 1060. DOI: $10.3390 /$ su 11041060

Harahap, B. M., and Kresnowati, M. T. A. P. (2018). "Moderate pretreatment of oil palm empty fruit bunches for optimal production of xylitol via enzymatic hydrolysis and fermentation," Biomass Conversion and Biorefinery 8(2), 255-263. DOI: 10.1007/s13399-017-0299-x

Hassan, M. A., Farid, M. A. A., Shirai, Y., Ariffin, H., Othman, M. R., Samsudin, M. H., and Hasan, M. Y. (2019). "Oil palm biomass biorefinery for sustainable production of renewable materials," Biotechnology Journal 14(6). DOI: 10.1002/biot.201800394

Hassan, S. S., Williams, G. A., and Jaiswal, A. K. (2018). "Emerging technologies for the pretreatment of lignocellulosic biomass," Bioresource Technology 262, 310-318. DOI: 10.1016/j.biortech.2018.04.099

Hastuti, N., Kanomata, K., and Kitaoka, T. (2018). "Hydrochloric acid hydrolysis of pulps from oil palm empty fruit bunches to produce cellulose nanocrystals," Journal of Polymers and the Environment 26(9), 3698-3709. DOI:10.1007/s10924-018-1248-x 
Hazeena, S. H., Salini, C. N., Sindhu, R., Pandey, A., and Binod, P. (2019).

"Simultaneous saccharification and fermentation of oil palm front for the production of 2,3-butanediol," Bioresource Technology 278, 145-149. DOI:

10.1016/j.biortech.2019.01.042

He, C., Tang, C., Li, C., Yuan, J., Tran, K.-Q., Bach, Q.-V., Qiu, R., and Yang, Y. (2018). "Wet torrefaction of biomass for high quality solid fuel production: A review," Renewable and Sustainable Energy Reviews 91, 259-271. DOI: 10.1016/j.rser.2018.03.097

Ho, M. C., Wu, T. Y., Chee, S. W. Q., Ngang, C. Y., Chew, I. M. L., Teoh, W. H., Md. Jahim, J., and Mohammad, A. W. (2019). "An application of low concentration alkaline hydrogen peroxide at non-severe pretreatment conditions together with deep eutectic solvent to improve delignification of oil palm fronds," Cellulose 26(16), 8557-8573. DOI: 10.1007/s10570-019-02646-z

Hosseini Koupaie, E., Dahadha, S., Bazyar Lakeh, A. A., Azizi, A., and Elbeshbishy, E. (2019). "Enzymatic pretreatment of lignocellulosic biomass for enhanced biomethane production-A review," Journal of Environmental Management 233, 774-784. DOI: 10.1016/j.jenvman.2018.09.106

Houtmeyers, S., Degrève, J., Willems, K., Dewil, R., and Appels, L. (2014). “Comparing the influence of low power ultrasonic and microwave pre-treatments on the solubilisation and semi-continuous anaerobic digestion of waste activated sludge," Bioresource Technology 171, 44-49. DOI: 10.1016/j.biortech.2014.08.029

Hussin, M. H., Bello, I., Hamidon, T. S., Bakar, M. A., Mohamad, A. A., and Haafiz, M. M. (2020). "Physico-chemical and conductivity studies of microcrystalline cellulose (mcc) extracted from oil palm fronds as a susceptible filler in pla-litfsi polymer electrolyte," Journal of Oil Palm Research 32(2), 271-285. DOI: 10.21894/jopr.2020.0023

Isa, M. H., Wong, L.-P., Bashir, M. J. K., Shafiq, N., Kutty, S. R. M., Farooqi, I. H., and Lee, H. C. (2020). "Improved anaerobic digestion of palm oil mill effluent and biogas production by ultrasonication pretreatment," Science of The Total Environment 722, 137833. DOI: 10.1016/j.scitotenv.2020.137833

Islam, M. T., Alam, M. Z., Al-Mamun, A., Elgharbawy, A. A., and Riyadi, F. A. (2017a). "Development of enzymatic pretreatment of palm oil mill effluent for monomers towards biogas production," Journal of Advanced Research in Materials Science 38(1), 39-44.

Islam, S. M. M., Li, Q., Al Loman, A., and Ju, L.-K. (2017b). " $\mathrm{CO}_{2}-\mathrm{H}_{2} \mathrm{O}$ based pretreatment and enzyme hydrolysis of soybean hulls," Enzyme and Microbial Technology 106, 18-27. DOI: 10.1016/j.enzmictec.2017.06.011

Jusri, N. A. A., Azizan, A., Zain, Z. S. Z., and Rahman, A. M. F. (2019). "Effect of electron beam irradiation and ionic liquid combined pretreatment method on various lignocellulosic biomass," Key Engineering Materials 797, 351-358. DOI: 10.4028/www.scientific.net/KEM.797.351

Kamsani, N., Salleh, M. M., Basri, S. A., Mohamad, S. E., Aziz, S. A., and Kamaruddin, K. (2018). "Effects of surfactant on the enzymatic degradation of oil palm empty fruit bunch (OPEFB)," Waste and Biomass Valorization 9(5), 845-852. DOI: 10.1007/s12649-017-9838-8

Kapoor, M., Semwal, S., Gaur, R., Kumar, R., Gupta, R. P., and Puri, S. K. (2018). "The pretreatment technologies for deconstruction of lignocellulosic biomass," in: Waste to 
Wealth, R. R. Singhania, R. A. Agarwal, R. P. Kumar, and R. K. Sukumaran (eds)., Springer, Singapore, pp. 395-421. DOI: 10.1007/978-981-10-7431-8_17

Kasim, F., Syamsu, K., Setyaningsih, D., Suryadarma, P., and Sudirman. (2018). "The effect of pretreatment of microwave heating on efficiency of hydrolysis time and $\alpha$ cellulosic characteristics of palm oil waste biomass," Indonesian Journal of Materials Science 20(1), 21-28. DOI: 10.17146/jsmi.2018.20.1.5408

Kim, S. (2018). "Enhancing bioethanol productivity using alkali-pretreated empty palm fruit bunch fiber hydrolysate," BioMed Research International 2018. DOI: $10.1155 / 2018 / 5272935$

Kumar, M. N., Ravikumar, R., Thenmozhi, S., Kumar, M. R., and Shankar, M. K. (2019). "Choice of pretreatment technology for sustainable production of bioethanol from lignocellulosic biomass: Bottle necks and recommendations," Waste and Biomass Valorization 10, 1693-1709. DOI: 10.1007/s12649-017-0177-6

Kunasundari, B., Arai, T., Sudesh, K., Hashim, R., Sulaiman, O., Stalin, N. J., and Kosugi, A. (2017). "Detoxification of sap from felled oil palm trunks for the efficient production of lactic acid, "Applied Biochemistry and Biotechnology 183(1), 412-425. DOI:10.1007/s12010-017-2454-z

Lai, L. W., and Idris, A. (2016). "Comparison of steam-alkali-chemical and microwavealkali pretreatment for enhancing the enzymatic saccharification of oil palm trunk," Renewable Energy 99, 738-746. DOI: 10.1016/j.renene.2016.07.059

Latif, A. A., Harun, S., Sajab, M. S., Markom, M., and Jahim, J. M. (2018). “Ammoniabased pretreatment for ligno-cellulosic biomass conversion - An overview," Journal of Engineering Science and Technology 13(6), 1595-1620.

Latif, N. H. A., Rahim, A. A., Brosse, N., and Hussin, M. H. (2019). “The structural characterization and antioxidant properties of oil palm fronds lignin incorporated with p-hydroxyacetophenone," International Journal of Biological Macromolecules 130, 947-957. DOI: 10.1016/j.ijbiomac.2019.03.032

Lee, C. L., H'ng, P. S., Paridah, M. T., Chin, K. L., Rashid, U., Maminski, M., Go, W. Z., Nazrin, R. A. R., Rosli, S. N. A., and Khoo, P. S. (2018). "Production of bioadsorbent from phosphoric acid pretreated palm kernel shell and coconut shell by two-stage continuous physical activation via $\mathrm{N}_{2}$ and air," Royal Society Open Science 5(12). DOI: $10.1098 /$ rsos. 180775

Lee, J. T. E., Khan, M. U., Tian, H., Ee, A. W. L., Lim, E. Y., Dai, Y., Tong, Y. W., and Ahring, B. K. (2020). "Improving methane yield of oil palm empty fruit bunches by wet oxidation pretreatment: Mesophilic and thermophilic anaerobic digestion conditions and the associated global warming potential effects," Energy Conversion and Management 225, 113438. DOI: 10.1016/j.enconman.2020.113438

Lim, H. K., Lee, K. I., Hwang, D. W., and Hwang, I. T. (2016). “Complete saccharification of cellulose through chemo-enzymatic hydrolysis," Biomass and Bioenergy 94, 31-38. DOI: 10.1016/j.biombioe.2016.08.016

Liu, Q., Li, K., Liu, C.-G., Zhao, X.-Q., Bai, F.-W., Sakdaronnarong, C., Srinophakun, P., and Srinophakun, T. R. (2020). "Complex effects of wax on ionic liquid pretreatment of oil palm empty fruit bunch," Industrial Crops and Products 152, 112526. DOI:10.1016/j.indcrop.2020.112526

Loow, Y.-L., and Wu, T. Y. (2018). "Transformation of oil palm fronds into pentose sugars using copper (II) sulfate pentahydrate with the assistance of chemical additive," Journal of Environmental Management 216, 192-203. DOI: 10.1016/j.jenvman.2017.04.084 
López-Linares, J. C., García-Cubero, M. T., Lucas, S., González-Benito, G., and Coca, M. (2019). "Microwave assisted hydrothermal as greener pretreatment of brewer's spent grains for biobutanol production," Chemical Engineering Journal 368, 1045 1055. DOI: 10.1016/j.cej.2019.03.032

Mahmood, H., Moniruzzaman, M., Iqbal, T., Yusup, S., Rashid, M., and Raza, A. (2019). "Comparative effect of ionic liquids pretreatment on thermogravimetric kinetics of crude oil palm biomass for possible sustainable exploitation," Journal of Molecular Liquids 282, 88-96. DOI: 10.1016/j.molliq.2019.02.133

Mahmood, H., Moniruzzaman, M., Yusup, S., and Akil, H. M. (2016). "Pretreatment of oil palm biomass with ionic liquids: A new approach for fabrication of green composite board," Journal of Cleaner Production 126, 677-685. DOI: 10.1016/j.jclepro.2016.02.138

Mahmood, H., Moniruzzaman, M., Yusup, S., and Akil, H. M. (2018). "Ionic liquid pretreatment at high solids loading: A clean approach for fabrication of renewable resource based particulate composites," Polymer Composites 39(6), 1994-2003. DOI: $10.1002 /$ pc. 24159

Manaf, S. F. A., Jahim, J. M., Harun, S., and Luthfi, A. A. I. (2018). "Fractionation of oil palm fronds (OPF) hemicellulose using dilute nitric acid for fermentative production of xylitol," Industrial Crops and Products 115, 6-15. DOI:

10.1016/j.indcrop.2018.01.067

Mardawati, E., Badruzaman, I., Nurjanah, S., and Bindar, Y. (2018). "Effect of organosolv pretreatment on delignification for bioethanol feedstock from oil palm empty fruit bunch (OPEFB)," in: IOP Conference Series: Earth and Environmental Science 209, Bogor, Indonesia. DOI: 10.1088/1755-1315/209/1/012009

Mardawati, E., Herliansah, H., Suryadi, E., Hanidah, I. I., Setiasih, I. S., Andoyo, R., Sukarminah, E., Djali, M., Rialita, T., and Cahyana, Y. (2019). "Optimization of particle size, moisture content and reaction time of oil palm empty fruit bunch through ozonolysis pretreatment," Journal of the Japan Institute of Energy 98(6), 132-138. DOI: 10.3775/jie.98.132

Mardawati, E., Putri, A. V., Yuliana, T., Rahimah, S., Nurjanah, S., and Hanidah, I. (2019). "Effects of substrate concentration on bioethanol production from oil palm empty fruit bunches with simultaneous saccharification and fermentation (SSF)," in: IOP Conference Series: Earth and Environmental Science 230, Malang, Indonesia. DOI: $10.1088 / 1755-1315 / 230 / 1 / 012079$

Medina, J. D. C., Woiciechowski, A. L., Filho, A. Z., Brar, S. K., Júnior, A. I. M., and Soccol, C. R. (2018). "Energetic and economic analysis of ethanol, xylitol and lignin production using oil palm empty fruit bunches from a Brazilian factory," Journal of Cleaner Production 195, 44-55. DOI: 10.1016/j.jclepro.2018.05.189

Medina, J. D. C., Woiciechowski, A., Filho, A. Z., Nigam, P. S., Ramos, L. P., and Soccol, C. R. (2016). "Steam explosion pretreatment of oil palm empty fruit bunches (EFB) using autocatalytic hydrolysis: A biorefinery approach," Bioresource Technology 199, 173-180. DOI: 10.1016/j.biortech.2015.08.126

Megashah, L. N., Ariffin, H., Zakaria, M. R., and Ando, Y. (2018b). "Characteristics of cellulose from oil palm mesocarp fibres extracted by multi-step pretreatment methods," in: IOP Conference Series: Materials Science and Engineering 368, Selangor, Malaysia. DOI: 10.1088/1757-899X/368/1/012001

Megashah, L. N., Ariffin, H., Zakaria, M. R., and Hassan, M. A. (2018a). "Properties of cellulose extract from different types of oil palm biomass," in: IOP Conference 
Series: Materials Science and Engineering 368, Selangor, Malaysia. DOI: 10.1088/1757-899X/368/1/012049

Mittal, A., Katahira, R., Donohoe, B. S., Black, B. A., Pattathil, S., Stringer, J. M., and Beckham, G. T. (2017). "Alkaline peroxide delignification of corn stover," ACS Sustainable Chemistry \& Engineering 5(7), 6310-6321. DOI: 10.1021/acssuschemeng.7b01424

Mohtar, S. S., Tengku Malim Busu, T. N. Z., Md Noor, A. M., Shaari, N., and Mat, H. (2017). "An ionic liquid treatment and fractionation of cellulose, hemicellulose and lignin from oil palm empty fruit bunch," Carbohydrate Polymers 166, 291-299. DOI: 10.1016/j.carbpol.2017.02.102

Moniruzzaman, M., and Goto, M. (2018). "Ionic liquid pretreatment of lignocellulosic biomass for enhanced enzymatic delignification," in: Application of Ionic Liquids in Biotechnology, T. Itoh and Y.-M. Koo (eds.), Springer, Cham, Switzerland, pp. 6177. DOI: 10.1007/10_2018_64

Moreno, A. D., Tomás-Pejó, E., Ballesteros, M., and Negro, M. J. (2019). “Chapter 16 Pretreatment technologies for lignocellulosic biomass deconstruction within a biorefinery perspective," in: Biofuels: Alternative Feedstocks and Conversion Processes for the Production of Liquid and Gaseous Biofuels (Second Edition), A. Pandey, C. Larroche, C.-G. Dussap, E. Gnansounou, S. K. Khanal, and S. Ricke (eds.), Academic Press, London, UK, pp. 379-399. DOI: 10.1016/B978-0-12-8168561.00016-6

Mun, L. K. D. (2015). "Potential for waste-to-energy in Malaysia focus: Biomass, Malaysia Biomass Industries Confederation (MBIC2020)," Waste to Energy in East Malaysia Programme, Frankfurt.

Nabilah-Jansar, K., Roslan, A. M., and Hassan, M. A. (2018). "Review article: Appropriate hydrothermal pretreatment of oil palm biomass in palm oil mill," Pertanika Journal of Scholarly Research Reviews 4(1), 31-40.

Nadia, A., Rodiansono, R., and Sunardi, S. (2018a). "Investigation of fast hot compressed water pretreatment of oil palm fronds for fermentable sugar production," AIP Conference Proceedings 2026. DOI: 10.1063/1.5064985

Nadia, A., Sunardi, S., and Rodiansono, R. (2018b). "Hydrothermal pretreatment of oil palm fronds for increasing enzymatic saccharification," AIP Conference Proceedings 2021. DOI: $10.1063 / 1.5062726$

Namondo, B. V., Foba-Tendo, J., Etape, E. P., and Krause, R. W. M. (2018). "Potential of blended biomass feedstock from some species of raffia palm (Raffia farinifera, Raffia hookeri and Raffia vinifera) and oil palm empty fruit bunch (OPEFB) from Cameroon," African Journal of Pure and Applied Chemistry 12(4), 25-33. DOI: 10.5897/AJPAC2018.0753

New, E. K., Wu, T. Y., Lee, C. B. T. L., Poon, Z. Y., Loow, Y.-L., Foo, L. Y. W., Procentese, A., Siow, L. F., Teoh, W. H., Daud, N. N. N., et al. (2019). "Potential use of pure and diluted choline chloride-based deep eutectic solvent in delignification of oil palm fronds," Process Safety and Environmental Protection 123, 190-198. DOI: 10.1016/j.psep.2018.11.015

Nik Mahmud, N. A., Baharuddin, A. S., Bahrin, E. K., Sulaiman, A., Naim, M. N., Zakaria, R., Hassan, M. A., Nishida, H., and Shirai, Y. (2013). "Enzymatic saccharification of oil palm mesocarp fiber (OPMF) treated with superheated steam," BioResources 8(1), 1320-1331. DOI: 10.15376/biores.8.1.1320-1331 
Nlandu, H., Belkacemi, K., Chorfa, N., Elkoun, S., Robert, M., and Hamoudi, S. (2020). "Flax nanofibrils production via supercritical carbon dioxide pre-treatment and enzymatic hydrolysis," The Canadian Journal of Chemical Engineering 98(1), 84-95. doi:10.1002/cjce.23596

Nordin, N. I. A. A., Ariffin, H., Andou, Y., Hassan, M. A., Shirai, Y., Nishida, H., Yunus, W. M. Z. W., Karuppuchamy, S., and Ibrahim, N. A. (2013). "Modification of oil palm mesocarp fiber characteristics using superheated steam treatment," Molecules 18(8), 9132-9146. DOI: 10.3390/molecules 18089132

Noorshamsiana, A. W., Nur Eliyanti, A. O., Fatiha, I., and Astimar, A. A. (2017). "A review on extraction processes of lignocellulosic chemicals from oil palm biomass," Journal of Oil Palm Research 29, 512-527. DOI: 10.21894/jopr.2017.00016

Noparat, P., Prasertsan, P., O-Thong, S., and Pan, X. (2015). "Dilute acid pretreatment of oil palm trunk biomass at high temperature for enzymatic hydrolysis," Energy Procedia 79, 924-929. DOI: 10.1016/j.egypro.2015.11.588

Norrrahim, M. N. F., Ariffin, H., Yasim-Anuar, T. A. T., Ghaemi, F., Hassan, M. A., Ibrahim, N. A., Ngee, J. L. H., and Yunus, W. M. Z. W. (2018). "Superheated steam pretreatment of cellulose affects its electrospinnability for microfibrillated cellulose production," Cellulose 25(7), 3853-3859. DOI: 10.1007/s10570-018-1859-3

Nurfahmi, Ong, H. C., Jan, B. M., Tong, C. W., Fauzi, H., and Chen, W.-H. (2016). "Effects of organosolv pretreatment and acid hydrolysis on palm empty fruit bunch (PEFB) as bioethanol feedstock," Biomass and Bioenergy 95, 78-83. DOI: 10.1016/j.biombioe.2016.09.008

Ofori-Boateng, C., and Lee, K. T. (2014). "Ultrasonic-assisted simultaneous saccharification and fermentation of pretreated oil palm fronds for sustainable bioethanol production," Fuel 119, 285-291. DOI: 10.1016/j.fuel.2013.11.064

Oktaviani, M., Hermiati, E., Thontowi, A., Laksana, R. P. B., Kholida, L. N., Andriani, A., and Mangunwardoyo, W. (2019). "Production of xylose, glucose, and other products from tropical lignocellulose biomass by using maleic acid pretreatment," in: IOP Conference Series: Earth and Environmental Science 251, Tangerang, Indonesia. DOI: $10.1088 / 1755-1315 / 251 / 1 / 012013$

Omar, W. N. N. W., and Amin, N. A. S. (2016). "Multi response optimization of oil palm frond pretreatment by ozonolysis," Industrial crops and Products 85, 389-402. DOI: 10.1016/j.indcrop.2016.01.027

Ong, V. Z., Wu, T. Y., Lee, C. B. T. L., Cheong, N. W. R., and Shak, K. P. Y. (2019). "Sequential ultrasonication and deep eutectic solvent pretreatment to remove lignin and recover xylose from oil palm fronds," Ultrasonics Sonochemistry 58, 104598. DOI: 10.1016/j.ultsonch.2019.05.015

Onoja, E., Chandren, S., Razak, F. I. A., Mahat, N. A., and Wahab, R. A. (2019). "Oil palm (Elaeis guineensis) biomass in Malaysia: The present and future prospects," Waste and Biomass Valorization 10, 2099-2117. DOI: 10.1007/s12649-018-0258-1

Ouyang, X., Chen, L., Zhang, S., Yuan, Q., Wang, W., and Linhardt, R. J. (2018). "Effect of simultaneous steam explosion and alkaline depolymerization on corncob lignin and cellulose structure," Chemical and Biochemical Engineering Quarterly 32(2), 177189. DOI: 10.15255/CABEQ.2017.1251

Pangsang, N., Rattanapan, U., Thanapimmetha, A., Srinopphakhun, P., Liu, C.-G., Zhao, X.-Q., Bai, F.-W., and Sakdaronnarong, C. (2019). "Chemical-free fractionation of palm empty fruit bunch and palm fiber by hot-compressed water technique for ethanol production," Energy Reports 5, 337-348. DOI: 10.1016/j.egyr.2019.02.008 
Pangsang, N., Sakdaronnarong, C., Thanapimmetha, A., and Srinophakun, P. (2018). "High ethanol production from oil palm empty fruit bunch pretreated by hotcompressed water technique," in: 2018 IEEE 5th International Conference on Engineering Technologies and Applied Sciences (ICETAS), Bangkok, Thailand. DOI: 10.1109/ICETAS.2018.8629187

Peinemann, J. C., and Pleissner, D. (2020). "Continuous pretreatment, hydrolysis, and fermentation of organic residues for the production of biochemicals," Bioresource Technology 295. DOI: 10.1016/j.biortech.2019.122256

Perrone, O. M., Bordignon, S. E., Boscolo, M., Gomes, E., and da Silva, R. (2018). "Ozonolysis applied to lignocellulosic biomass," in: Bioethanol and Beyond: Advances in Production Process and Future Directions, M. Brienzo (ed.), Nova Science Publishers, Inc., Hauppauge, NY, USA, pp. 145-166.

Rafatullah, M., Ahmad, T., Ghazali, A., Sulaiman, O., Danish, M., and Hashim, R. (2013). "Oil palm biomass as a precursor of activated carbons: A review," Critical Reviews in Environmental Science and Technology 43(11), 1117-1161. DOI: 10.1080/10934529.2011.627039

Rahman, A. Z. A., and Amin, N. A. S. (2019). "Environmental sustainability assessment of palm lignocellulosic biomass pretreatment methods," Chemical Engineering Transactions 72, 13-18. DOI: 10.3303/CET1972003

Rahman, N. F. A., Harun, S., Sajab, M. S., Zubairi, S. I., Markom, M., Jahim, J. M., Nor, M. T. M., Abdullah, M. A., and Hashim, N. (2018). "Boosting enzymatic hydrolysis of pressurized ammonium hydroxide pretreated empty fruit bunch using response surface methodology," Journal of Engineering Science and Technology 13(8), 24212445.

Rashid, T., Gnanasundaram, N., Appusamy, A., Kait, C. F., and Thanabalan, M. (2018). "Enhanced lignin extraction from different species of oil palm biomass: Kinetics and optimization of extraction conditions," Industrial Crops and Products 116, 122-136. DOI: 10.1016/j.indcrop.2018.02.056

Rattanaporn, K., Tantayotai, P., Phusantisampan, T., Pornwongthong, P., and Sriariyanun, M. (2018). "Organic acid pretreatment of oil palm trunk: Effect on enzymatic saccharification and ethanol production," Bioprocess and Biosystems Engineering 41(4), 467-477. DOI: 10.1007/s00449-017-1881-0

Razali, N. A. A. M., Ibrahim, M. F., Bahrin, E. K., and Abd-Aziz, S. (2018). "Optimisation of simultaneous saccharification and fermentation (SSF) for biobutanol production using pretreated oil palm empty fruit bunch," Molecules 23(8). DOI: 10.3390/molecules23081944

Rigual, V., Santos, T. M., Domínguez, J. C., Alonso, M. V., Oliet, M., and Rodriguez, F. (2018). "Evaluation of hardwood and softwood fractionation using autohydrolysis and ionic liquid microwave pretreatment," Biomass and Bioenergy 117, 190-197. DOI: 10.1016/j.biombioe.2018.07.014

Risanto, L., Fitria, Fajriutami, T., and Hermiati, E. (2018). "Enzymatic saccharification of liquid hot water and dilute sulfuric acid pretreated oil palm empty fruit bunch and sugarcane bagasse," in: IOP Conference Series: Earth and Environmental Science 141, Bogor, Indonesia. DOI: 10.1088/1755-1315/141/1/012025

Rizal, N. F. A. A., Ibrahim, M. F., Zakaria, M. R., Abd-Aziz, S., Yee, P. L., and Hassan, M. A. (2018a). "Pre-treatment of oil palm biomass for fermentable sugars production," Molecules 23(6). DOI: 10.3390/molecules23061381 
Rizal, N. F. A. A., Ibrahim, M. F., Zakaria, M. R., Bahrin, E. K., Abd-Aziz, S., and Hassan, M. A. (2018b). "Combination of superheated steam with laccase pretreatment together with size reduction to enhance enzymatic hydrolysis of oil palm biomass," Molecules 23(4). DOI: 10.3390/molecules23040811

Rupani, P. F., Alkarkhi, A. F. M., Shahadat, M., Embrandiri, A., El-Mesery, H. S., Wang, H., and Shao, W. (2019). "Bio-optimization of chemical parameters and earthworm biomass for efficient vermicomposting of different palm oil mill waste mixtures," International Journal of Environmental Research and Public Health 16(12). DOI: 10.3390/ijerph16122092

Sari, E., Effendy, M., Kanani, N., Wardalia, and Rusdi. (2018). "Utilization of empty fruit bunch fiber of palm oil industry for bio-hydrogen production," International Journal on Advanced Science, Engineering and Information Technology 8(3), 842848. DOI: 10.18517/ijaseit.8.3.3985

Sasmal, S., and Mohanty, K. (2018). "Pretreatment of lignocellulosic biomass toward biofuel production," in: Biorefining of Biomass to Biofuels: Opportunities and Perception, S. Kumar and R. K. Sani (eds.), Springer, Cham, Switzerland, pp. 203221. DOI: 10.1007/978-3-319-67678-4_9

Satlewal, A., Agrawal, R., Bhagia, S., Sangoro, J., and Ragauskas, A. J. (2018). "Natural deep eutectic solvents for lignocellulosic biomass pretreatment: Recent developments, challenges and novel opportunities," Biotechnology Advances 36(8), 2032-2050. DOI: 10.1016/j.biotechadv.2018.08.009

Sebran, N. H., Gaik, L. P., and Hussain, A. S. (2018). "Structural analysis on the effect of base-catalysed delignification process parameters on palm oil empty fruit bunches fibres using glycome profiling," in: IOP Conference Series: Materials Science and Engineering 458, Kuala Lumpur, Malaysia. DOI: 10.1088/1757-899X/458/1/012070

Sharma, H. K., Xu, C., and Qin, W. (2019). "Biological pretreatment of lignocellulosic biomass for biofuels and bioproducts: An overview," Waste and Biomass Valorization 10(2), 235-251. DOI: 10.1007/s12649-017-0059-y

Singh, J. K., Vyas, P., Dubey, A., Upadhyaya, C. P., Kothari, R., Tyagi, V. V., and Kumar, A. (2018). "Assessment of different pretreatment technologies for efficient bioconversion of lignocellulose to ethanol," Frontiers in Bioscience 10, 350-371. DOI: $10.2741 / \mathrm{s} 521$

Siramon, P., Punsuvon, V., and Vaithanomsat, P. (2018). "Production of bioethanol from oil palm empty fruit bunch via acid impregnation-steam explosion pretreatment," Waste and Biomass Valorization 9(8), 1407-1414. DOI: 10.1007/s12649-017-9924-y

Sohni, S., Hashim, R., Nidaullah, H., Sulaiman, O., Leh, C. P., Lamaming, J., Arai, T., and Kosugi, A. (2020). "Enhancing the enzymatic digestibility of oil palm biomass using supercritical carbon dioxide-based pretreatment towards biorefinery application," Industrial crops and Products 157, 112923. DOI: 10.1016/j.indcrop.2020.112923

Sukiran, M. A., Loh, S. K., and Bakar, N. A. (2018). "Conversion of pre-treated oil palm empty fruit bunches into bio-oil and bio-char via fast pyrolysis," Journal of Oil Palm Resesearch 30(1), 121-129. DOI: 10.21894/jopr.2018.0006

Sun, S., Sun, S., Cao, X., and Sun, R. (2016). "The role of pretreatment in improving the enzymatic hydrolysis of lignocellulosic materials," Bioresource Technology 199, 4958. DOI:10.1016/j.biortech.2015.08.061

Surya, E. A., Rahman, S. F., Zulamraini, S., and Gozan, M. (2018). "Preliminary plant design of Escherichia coli BPPTCC-EgRK2 cell culture for recombinant cellulase 
production using oil palm empty fruit bunch (OPEFB) as substrate," in: IOP Conference Series: Earth and Environmental Science 141, Bogor, Indonesia. DOI: 10.1088/1755-1315/141/1/012030

Syarifah, S. M., Kassim, A. S. M., Aripin, A. M., Ishak, N., Fadilat, A., and Adnan, S. (2019). "Bio-mechanical pulping of bacteria pre-treatment on oil palm biomass for handsheet production," International Journal of Engineering \& Technology 8(1.1), 177-183. DOI: 10.14419/ijet.v8i1.1.24657Published

Tahir, P. M., Owolabi, F. A. T., Shawkataly, A. K. H. P., Alkarkhi, A. F. M., Nwakaego, E. G., Kamilu, O. K. F., Chima, I. C., Rizal, S., and Ghazali, A. (2018). "Pulp and paper potentials of alkaline peroxide pre-treated of oil palm waste and industrial application," in: Palm Oil, V. Y. Waisundara (ed.), IntechOpen, London, UK, pp. 7590. DOI: 10.5772/intechopen.74430

Tajuddin, A. M., Harun, S., Sajab, M. S., Zubairi, S. I., Jahim, J. M., Markom, M., Nor, M. T. M., Abdullah, M. A., and Hashim, N. (2019). "Influence of deep eutectic solvent (DES) pretreatment on various chemical composition of empty fruit bunch (EFB)," International Journal of Engineering \& Technology 8(1.2), 266-274. DOI: 10.14419/ijet.v8i1.2.24913

Tan, Y. T., Ngoh, G. C., and Chua, A. S. M. (2018). "Evaluation of fractionation and delignification efficiencies of deep eutectic solvents on oil palm empty fruit bunch," Industrial Crops and Products 123, 271-277. DOI: 10.1016/j.indcrop.2018.06.091

Tang, P.-L., Abdul, P. M., Engliman, N. S., and Hassan, O. (2018). "Effects of pretreatment and enzyme cocktail composition on the sugars production from oil palm empty fruit bunch fiber (OPEFBF)," Cellulose 25(8), 4677-4694. DOI: 10.1007/s10570-018-1894-0

Tayyab, M., Noman, A., Islam, W., Waheed, S., Arafat, Y., Ali, F., Zaynab, M., Lin, S., Zhang, H., and Lin, W. (2018). "Bioethanol production from lignocellulosic biomass by environment-friendly pretreatment methods: A review," Applied Ecology and Environmental Research 16(1), 225-249. DOI: 10.15666/aeer/1601_225249

Thamsee, T., Cheirsilp, B., Yamsaengsung, R., Ruengpeerakul, T., Choojit, S., and Sangwichien, C. (2018). "Efficient of acid hydrolysis of oil palm empty fruit bunch residues for xylose and highly digestible cellulose pulp productions," Waste and Biomass Valorization 9(11), 2041-2051. DOI: 10.1007/s12649-017-9965-2

Thamsee, T., Choojit, S., Cheirsilp, B., Yamseangsung, R., Ruengpeerakul, T., and Sangwichien, C. (2019). "Combination of superheated steam explosion and alkaline autoclaving pretreatment for improvement of enzymatic digestibility of the oil palm tree residues as alternative sugar sources," Waste and Biomass Valorization 10, 30093023. DOI: $10.1007 / \mathrm{s} 12649-018-0292-\mathrm{z}$

Thi, S., and Lee, K. M. (2019). "Comparison of deep eutectic solvents (DES) on pretreatment of oil palm empty fruit bunch (OPEFB): Cellulose digestibility, structural and morphology changes," Bioresource Technology 282, 525-529. DOI: 10.1016/j.biortech.2019.03.065

Tian, S.-Q., Zhao, R.-Y., and Chen, Z.-C. (2018). "Review of the pretreatment and bioconversion of lignocellulosic biomass from wheat straw materials," Renewable and Sustainable Energy Reviews 91, 483-489. DOI: 10.1016/j.rser.2018.03.113

Trache, D., Tarchoun, A. F., Derradji, M., Hamidon, T. S., Masruchin, N., Brosse, N., and Hussin, M. H. (2020). "Nanocellulose: From fundamentals to advanced applications," Frontiers in Chemistry 8. DOI: 10.3389/fchem.2020.00392 
Tsegaye, B., Balomajumder, C., and Roy, P. (2019). "Microbial delignification and hydrolysis of lignocellulosic biomass to enhance biofuel production: An overview and future prospect," Bulletin of the National Research Centre 43(1). DOI: 10.1186/s42269-019-0094-X

Ummalyma, S. B., Supriya, R. D., Sindhu, R., Binod, P., Nair, R. B., Pandey, A., and Gnansounou, E. (2019). "Chapter 7 - Biological pretreatment of lignocellulosic biomassm - Current trends and future perspectives," in: Second and Third Generation of Feedstocks: The Evolution of Biofuels, A. Basile and F. Dalena (eds.), Elsevier, Amsterdam, The Netherlands, pp. 197-212. DOI: 10.1016/B978-0-12-8151624.00007-0

Waluyo, J., Anggraini, R. I. F., Kurniawan, H. H., and Sudiyani, Y. (2018). "Physical chemical characterization of alkali pretreatment for oil palm empty fruit bunch," AIP Conference Proceedings 2024(1). DOI: 10.1063/1.5064358

Wong, L.-P., Isa, M. H., and Bashir, M. J. K. (2018a). "Disintegration of palm oil mill effluent organic solids by ultrasonication: Optimization by response surface methodology," Process Safety and Environmental Protection 114, 123-132. DOI: 10.1016/j.psep.2017.12.012

Wong, L. P., Isa, M. H., Bashir, M. J. K., and Yaqub, A. (2018b). "Low frequency ultrasound treatment of palm oil mill effluent for solubilization of organic matter," Desalination and Water Treatment 108, 164-170. DOI: 10.5004/dwt.2018.21978

Yamaguchi, A., Sato, O., Mimura, N., and Shirai, M. (2016). "Catalytic production of sugar alcohols from lignocellulosic biomass," Catalysis Today 265, 199-202. DOI: 10.1016/j.cattod.2015.08.026

Yasim-Anuar, T. A. T., Ariffin, H., and Hassan, M. A. (2018). "Characterization of cellulose nanofiber from oil palm mesocarp fiber produced by ultrasonication," in: IOP Conference Series: Materials Science and Engineering 368, Selangor, Malaysia. DOI: 10.1088/1757-899X/368/1/012033

Yiin, C. L., Quitain, A. T., Yusup, S., Uemura, Y., Sasaki, M., and Kida, T. (2018c). "Sustainable green pretreatment approach to biomass-to-energy conversion using natural hydro-low-transition-temperature mixtures," Bioresource Technology 261, 361-369. DOI: 10.1016/j.biortech.2018.04.039

Yiin, C. L., Yusup, S., Quitain, A. T., Uemura, Y., Sasaki, M., and Kida, T. (2018a). "Thermogravimetric analysis and kinetic modeling of low-transition-temperature mixtures pretreated oil palm empty fruit bunch for possible maximum yield of pyrolysis oil," Bioresource Technology 255, 189-197. DOI: 10.1016/j.biortech.2018.01.132

Yiin, C. L., Yusup, S., Quitain, A. T., Uemura, Y., Sasaki, M., and Kida, T. (2018b). "Delignification kinetics of empty fruit bunch (EFB): A sustainable and green pretreatment approach using malic acid-based solvents," Clean Technologies and Environmental Policy 20(9), 1987-2000. DOI: 10.1007/s10098-018-1592-5

Yusof, S. J. H. M., Roslan, A. M., Ibrahim, K. N., Abdullah, S. S. S., Zakaria, M. R., Hassan, M. A., and Shirai, Y. (2018). "Environmental performance of bioethanol production from oil palm frond petiole sugars in an integrated palm biomass biorefinery," in: IOP Conference Series: Materials Science and Engineering 368, Selangor, Malaysia. DOI: 10.1088/1757-899X/368/1/012004

Zahari, M. A. K. M., Abdullah, S. S. S., Roslan, A. M., Ariffin, H., Shirai, Y., and Hassan, M. A. (2014). "Efficient utilization of oil palm frond for bio-based products 
and biorefinery," Journal of Cleaner Production 65, 252-260. DOI:

10.1016/j.jclepro.2013.10.007

Zakaria, M. R., Norrrahim, M. N. F., Hirata, S., and Hassan, M. A. (2015).

"Hydrothermal and wet disk milling pretreatment for high conversion of biosugars from oil palm mesocarp fiber," Bioresource Technology 181, 263-269. DOI: 10.1016/j.biortech.2015.01.072

Zawawi, A. Z., Gaik, L. P., Sebran, N. H., Othman, J., and Hussain, A. S. (2018). "An optimisation study on biomass delignification process using alkaline wash," Biomass Conversion and Biorefinery 8(1), 59-68. DOI: 10.1007/s13399-017-0246-X

Zhai, R., Hu, J., and Saddler, J. N. (2018). "Minimizing cellulase inhibition of whole slurry biomass hydrolysis through the addition of carbocation scavengers during acidcatalyzed pretreatment," Bioresource Technology 258, 12-17. DOI: 10.1016/j.biortech.2018.02.124

Zhang, H., Zhang, P., Ye, J., Wu, Y., Liu, J., Fang, W., Xu, D., Wang, B., Yan, L. and Zeng, G. (2018). "Comparison of various pretreatments for ethanol production enhancement from solid residue after rumen fluid digestion of rice straw," Bioresource Technology 247, 147-156. DOI: 10.1016/j.biortech.2017.09.065

Zhang, J., Feng, L., Wang, D., Zhang, R., Liu, G., and Cheng, G. (2014). "Thermogravimetric analysis of lignocellulosic biomass with ionic liquid pretreatment," Bioresource Technology 153, 379-382. DOI: 10.1016/j.biortech.2013.12.004

Zhao, M.-j., Xu, Q.-q., Li, G.-m., Zhang, Q.-Z., Zhou, D., Yin, J.-Z., and Zhan, H.-s. (2019). "Pretreatment of agricultural residues by supercritical $\mathrm{CO}_{2}$ at $50-80{ }^{\circ} \mathrm{C}$ to enhance enzymatic hydrolysis," Journal of Energy Chemistry 31, 39-45. doi:DOI: 10.1016/j.jechem.2018.05.003

Zhou, J., Ma, Y., Jia, Y., Pang, M., Cheng, G., and Cai, S. (2019). "Phenolic profiles, antioxidant activities and cytoprotective effects of different phenolic fractions from oil palm (Elaeis guineensis Jacq.) fruits treated by ultra-high pressure," Food Chemistry 288, 68-77. DOI: 10.1016/j.foodchem.2019.03.002

Zulkarnain, A., Bahrin, E. K., Ramli, N., Phang, L. Y., and Abd-Aziz, S. (2018). "Alkaline hydrolysate of oil palm empty fruit bunch as potential substrate for biovanillin production via two-step bioconversion," Waste and Biomass Valorization 9(1), 13-23. DOI: 10.1007/s12649-016-9745-4

Zulkefli, S., Abdulmalek, E., and Abdul Rahman, M. B. (2017). "Pretreatment of oil palm trunk in deep eutectic solvent and optimization of enzymatic hydrolysis of pretreated oil palm trunk," Renewable Energy 107, 36-41. DOI: 10.1016/j.renene.2017.01.037

Article submitted: June 18, 2020; Peer review completed: September 5, 2020; Revised version received and accepted: October 8, 2020; Published: October 20, 2020.

DOI: $10.15376 /$ biores.15.4.Diyanilla 